\title{
Postirradiation Examination of Peach Bottom HTGR Driver Fuel Element E06-01
}

\author{
F. F. Dyer \\ R. P. Wichner \\ W. J. Martin \\ L. L. Fairchild \\ R. J. Kedl \\ H. J. de Nordwall
}

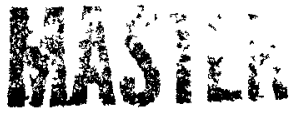

\section{OAK RIDGE NATIONAL LABORATORY}

OPERATED BY UNION CARBIDE CORPORATION FOR THE ENERGY RESEARCH AND DEVELOPMENT ADMINISTRATION 


\section{DISCLAIMER}

This report was prepared as an account of work sponsored by an agency of the United States Government. Neither the United States Government nor any agency Thereof, nor any of their employees, makes any warranty, express or implied, or assumes any legal liability or responsibility for the accuracy, completeness, or usefulness of any information, apparatus, product, or process disclosed, or represents that its use would not infringe privately owned rights. Reference herein to any specific commercial product, process, or service by trade name, trademark, manufacturer, or otherwise does not necessarily constitute or imply its endorsement, recommendation, or favoring by the United States Government or any agency thereof. The views and opinions of authors expressed herein do not necessarily state or reflect those of the United States Government or any agency thereof. 


\section{DISCLAIMER}

Portions of this document may be illegible in electronic image products. Images are produced from the best available original document. 


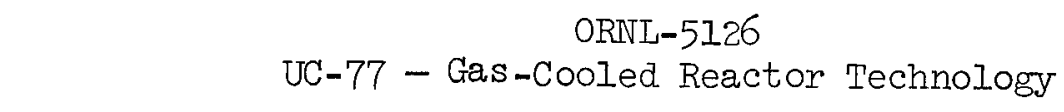

Contract No. W-7405-eng-26

CHEMICAL TECHNOLOGY DIVISION

POSTIRRADIATION EXAMINATION OF PEACH

BOTTOM HTGR DRIVER FUEL ETEMENT EO6-OI
F. F. Dyer*
R. P. Wichner
W. J. Martin
L. L. Fairchild
R. J. KedI**
H. J. de Nordwall ${ }^{\dagger}$

\footnotetext{
* On loan from the Analytical Chemistry Division. ** On loan from the Reactor Division.

Present address:

O.E.C.D. High Temperature Reactor Project (Dragon), A.E.E., Winfrith, Dorchester, Dorset, England.
}

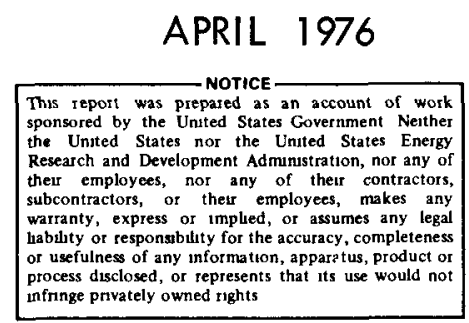

OAK RIDGE NATIONAL IABORATORY

Oak Ridge, Tennessee 37830 operated by

UNION CARBIDE CORPORATION

for the

ENERGY RESEARCH AND DEVELOPMENT ADMINISTRATION 
Printed in the United States of America Avallable from

National Technical Information Service

US Department of Commerce

5285 Port Royal Road, Sprıngfield, Virgınıa 22161

Price Printed Copy $\$ 500$, Microfiche $\$ 225$

This report was prepared as an account of work sponsored by the United States Government Neither the United States nor the Energy Research and Development Administration, nor any of their employees, nor any of their contractors, subcontractors, or their employees, makes any warranty, express or implied, or assumes any legal liability or responsibility for the accuracy, completeness or usefulness of any information, apparatus, product or process disclosed, or represents that its use would not infringe privately owned rights 


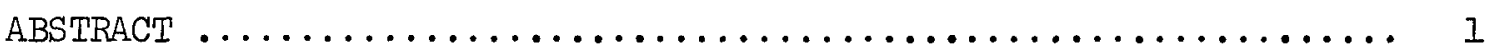

1. INTRODUCTION $\ldots \ldots \ldots \ldots \ldots \ldots \ldots \ldots \ldots \ldots \ldots \ldots \ldots \ldots \ldots \ldots \ldots$

1.1 Objectives $\ldots \ldots \ldots \ldots \ldots \ldots \ldots \ldots \ldots \ldots \ldots \ldots \ldots \ldots \ldots \ldots \ldots$

1.2 Sources of Information Concerning the Construction

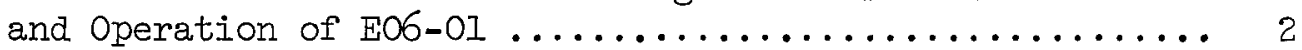

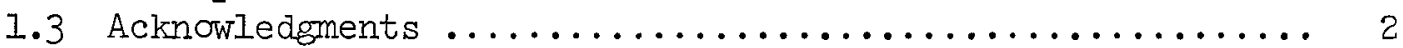

2. DESCRIPTION OF FUEL ELEMENT EO6-OI $\ldots \ldots \ldots \ldots \ldots \ldots \ldots \ldots \ldots$

2.1 Dimensions and Location in Core $\ldots \ldots \ldots \ldots \ldots \ldots \ldots \ldots \ldots$

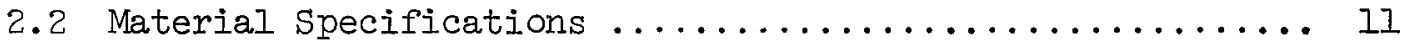

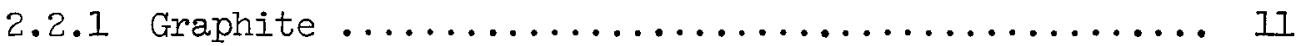

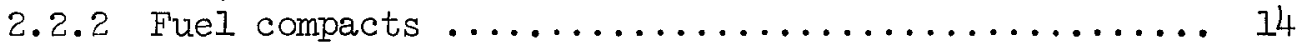

2.3 Operating History - Power, Temperature, and Fluence ..... 18

3. EXAMINATION PROCEDURES $\ldots \ldots \ldots \ldots \ldots \ldots \ldots \ldots \ldots \ldots \ldots \ldots \ldots \ldots$

3.I Visual and Photographic Examination .............. 21

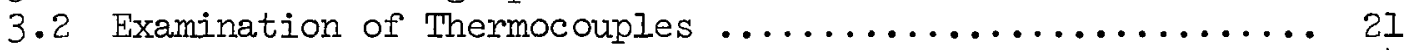

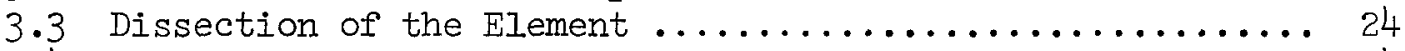

3.4 Metrology of Fuel, Sleeve, Spine, and Top Reflector ..... 24

3.5 Determination of Axial Distributions of Gamma-emitting

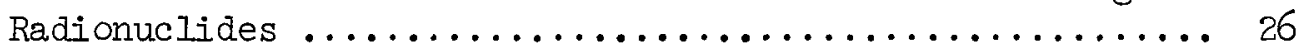

3.5.1 Top-reflector purge tube and porous plug ....... 26

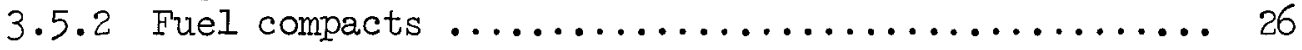

3.5.3 Sleeve, spine, and fission product trap ....... 27

3.6 Measurement of Radionuclides in Sections Cut from

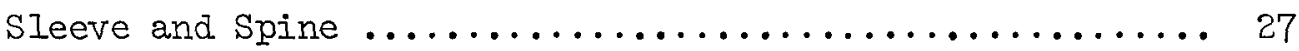

3.7 Measurement of Radial Distributions of Radionuclides

in Top Reflector, Sleeve, and spine .............. 28

3.8 Metallographic and Microprobe Examination of Fuel

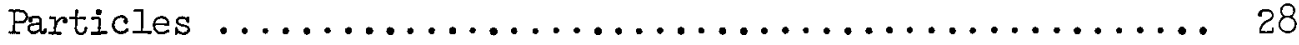

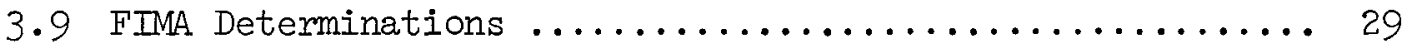

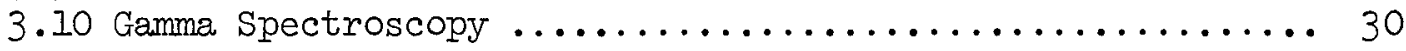

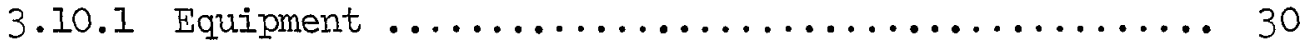

3.10.2 Counting procedures and counting efficiency

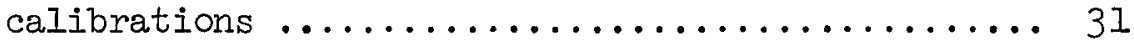

3.10 .3 Analyses of gamma spectra .................. 32

3.10.4 Mutual interferences of the measurements of

gamma rays 
4. RESULTS AND DISCUSSION $\ldots \ldots \ldots \ldots \ldots \ldots \ldots \ldots \ldots \ldots \ldots \ldots \ldots \ldots \ldots \ldots \ldots \ldots \ldots \ldots \ldots$

4.1 External Examinations and Metrology .............. 35

4.2 Axial Distributions and Inventories of Radionuclides .... 40

4.2.1 Axial distributions of radionuclides in the purge inlet tube and porous plug ............ 40

4.2.2 Axial distributions in the fueled region ....... 45

4.3 Radial Distributions of Radionuclides $\ldots \ldots \ldots \ldots \ldots \ldots$

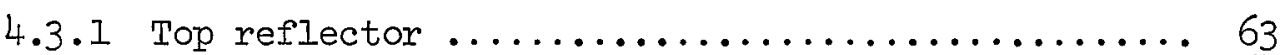

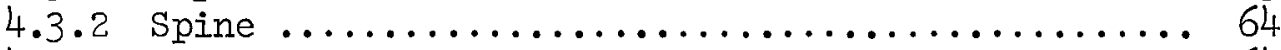

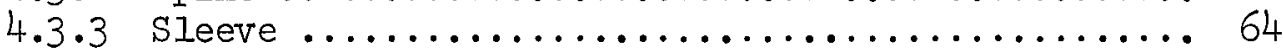

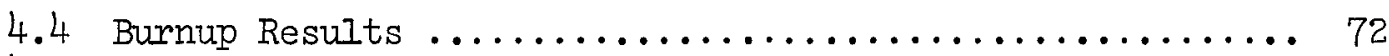

4.5 Comparison of Measured and Calculated Fission

Product Inventories .......................... 76

4.6 Summary of Radionuclide Inventories in Graphite

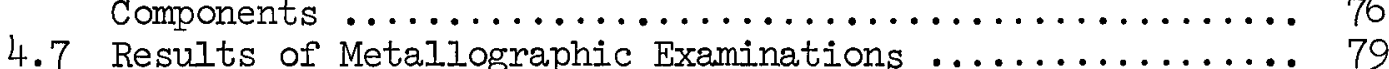

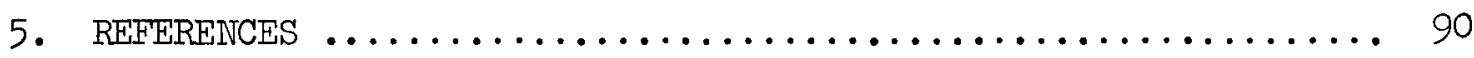




\title{
POSTIRRADIATION EXAMINATION OF PEACH BOTTOM HTGR
}

DRIVER FUEL ELEMENT EO6-01

\author{
F. F. Dyer* \\ R. P. Wichner \\ W. J. Martin \\ L. L. Fairchild \\ R. J. Kedl** \\ H. J. de Nordwall ${ }^{\dagger}$
}

ABSTRACT

This report describes the postirradiation examinations of driver fuel element E06-Ol, which had been irradiated an equivalent of 384 full-power days in Peach Bottom, Unit 1. The fuel element is described in detail and its temperature and irradiation service history briefly outlined. Results presented include: (1) visual observations; (2) critical dimensions of fuel compacts, sleeve, and spine; (3) axial distributions of garma-emitting nuclides plus ${ }^{3} \mathrm{H}$ and ${ }^{90} \mathrm{Sr}$; (4) radial distributions of these nuclides in the sleeve and spine at three axial locations in the fueled regions and three locations in the upper reflector; (5) metallographic examination of samples of fuel compact material; and (6) burnup determinations via radiochemical analyses at two compact locations.

\section{INTRODUCTION}

\subsection{Objectives}

As part of a fission product surveillance program on the Peach Bottom High Temperature Gas-Cooled Reactor (HTGR), we are conducting postirradiation examinations (PIE'S) on a series of driver (i.e., powerproducing) fuel elements from this reactor. The objective of the PIF's is to provide results showing the amounts and distributions of fission

\footnotetext{
* On loar from the Analytical Chemistry Division. * On Loan from the Reactor Division.

O.E.C.D. High Temperature Reactor Project (Dragon), A.E.E., Winfrith, Dorchester, Dorset, England.
} 
products in all components of the elements and a description of the physical condition of each element. The long-range goal of the surveillance work is to use the results of the PIE'S and examinations of other reactor components to test the degree of validity of presently formulated models and mechanisms for explaining fission product behavior in $H_{T} G R ' s$.

The present report consists mainly of a description of the procedures used and a summary of the results found in the PIE of fuel element E06-01. This element was received on January 12, 1973, after it had been operated for 384 equivalent full power days (EFPD's).

\subsection{Sources of Information Concerning the Construction and Operation of EO6-OI}

Information about the construction and operation of driver element E06-01 was obtained from the General Atomic Company (GAC). Portions of the engineering drawings supplied by CAC were redrawn for Figs. 2.2-2.6 (see Sect. 2.1). Descriptive information, material specifications, and operating history summarized in sects. 2.3 and 2.4 were obtained from the Peach Bottom Final Hazards Summary Report (FHSR), ${ }^{1}$ the Core 2 supplement to the FHSR, ${ }^{2}$ a report by Turner et al. ${ }^{3}$ which discusses the fuel performance of Core 2 after 630 EFPD's of operation, and a letter from Hoppe ${ }^{4}$ describing the service history of E06-01. More recent estimates of the irradiation and temperature history are provided in a letter from McCord to Wallroth. 5

\subsection{Acknowledgments}

We would like to acknowledge some of the personnel in a number of ORNI divisions who contributed the diverse skills required for this work. N. M. Atchley in the Remote Metallography Group of the Metals and Ceramics Division prepared the fuel compact samples for examination and obtained the photographs that appear in Sect. 4.7. S. E. Dismuke of the Operations Division was responsible for the metrology data on the compacts, sleeve, and spine pieces obtained in the HRLEL. J. L. Botts, I. C. Bate, and 
R. E. Eby of the Analytical Chemistry Division performed the reported radiochemical analyses of fuel particles and graphite samples.

\section{DESCRIPTION OF FUEL ELEMENT E06-01}

\subsection{Dimensions and Location in Core}

Fuel element EO6-01 was an instrumented, light-rhodium element located in the sixth row of segment $E$ of the core (see Fig. 2.1). As such, it was a so-called type-2 element, one of the four basic types of drivers indicated in Table 2.1. Type-2 elements comprised 564 of the total of 804 drivers on Core 2; however, only a small number of these contained thermocouples. Element EO6-OI was subjected to 384 EFPD's irradiation in the core.

Major components of the element, shown in Fig 2.2, are a top reflector assembly, a fuel-bearing middle section composed of three spine pieces, a sleeve, 30 fuel compacts, and a bottom reflector assembly. Externally, the element had the appearance of a solid graphite cylinder $8.89 \mathrm{~cm}$ (3.5 in.) in diameter and $365.7 \mathrm{~cm}$ (144 in.) Iong, with a grappling knob at the top for handling. Except for the fuel compacts, filter screen, and thermocouples, all components were made of graphite. The top reflector assembly, shown in Fig. 2.3, was threaded and cemented to the sleeve. A $0.64-\mathrm{cm}$-diam (1/4-in.-diam) hole down the center line of the reflector served as an inlet channel for the purge gas. A porous plug, cemented within the bottom of the top reflector, provided a pressure drop that controlled the flow rate of the purge gas. The sleeve, shown in detail in Fig. 2.4, was $292 \mathrm{~cm}$ (115 in.) long and extended from the top reflector to the bottom connector; it enclosed the fuel compacts, spine pieces, a bottom reflector piece, an internal fission product trap, and a filter screen below the trap.

Details of the fuel compacts and spine pieces are shown in Figs. 2.5 and 2.6 respectively. The central fueled region consisted of 30 fuel compacts stacked on three 30-in. spine pieces and was enclosed by the 
4

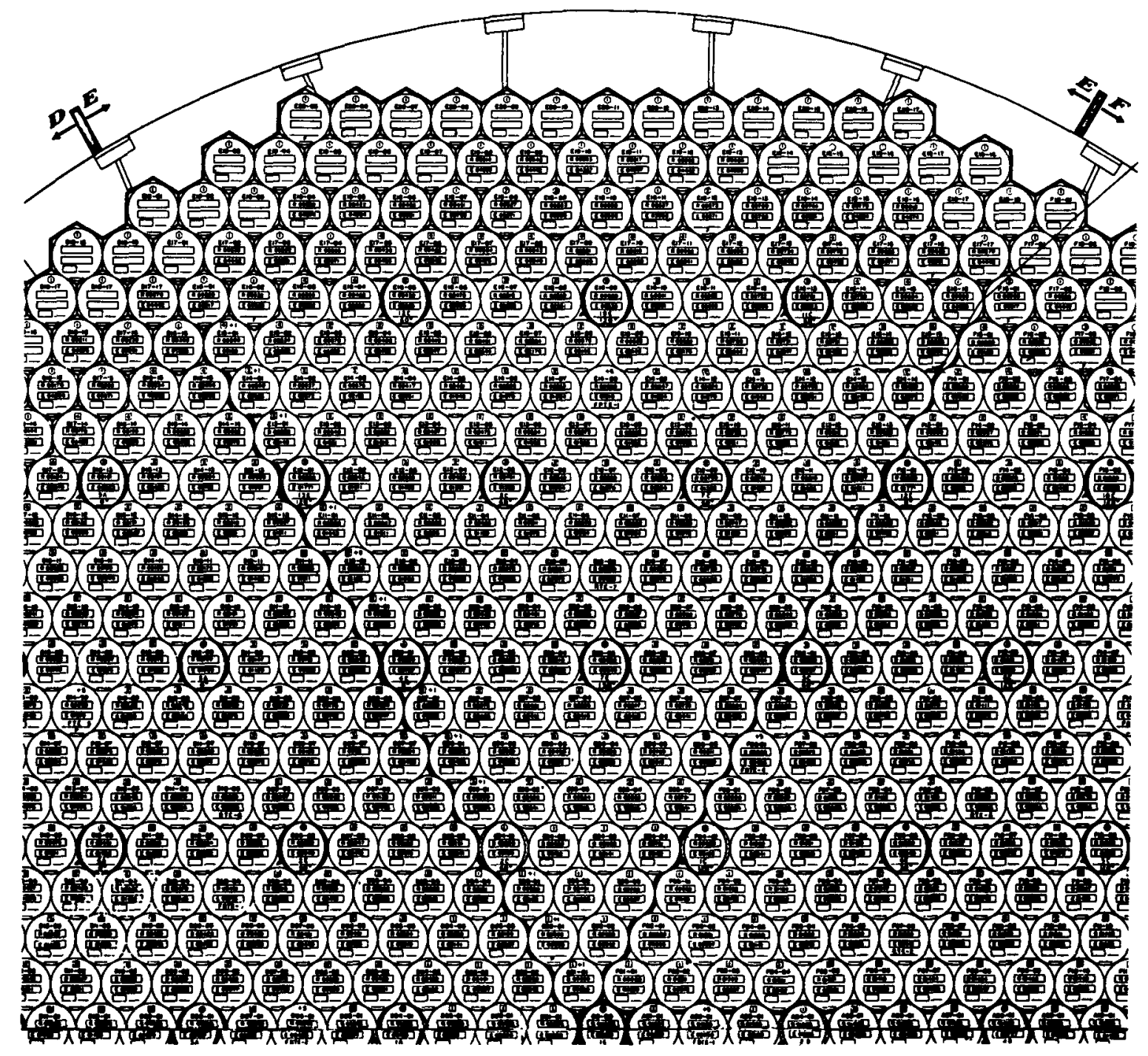

Fig. 2.1. Map of Peach Bottom Core 2, showing Sector E. 
Table 2.1. Fuel element categories and initial (nominal) loadings

\begin{tabular}{|c|c|c|c|c|}
\hline \multirow[b]{2}{*}{ Description } & \multicolumn{4}{|c|}{ Type of fuel element } \\
\hline & $\begin{array}{c}1 \\
\text { Heavy rhodium }\end{array}$ & $\begin{array}{c}2 \\
(\mathrm{E} 06-01) \\
\text { Light rhodium }\end{array}$ & $\begin{array}{l}3 \\
\text { Light rhodium, } \\
\text { with burnable } \\
\text { poison }\end{array}$ & $\begin{array}{l}\text { Heavy thorium, } \\
\text { light uranium }\end{array}$ \\
\hline Spine & Solid graphite & Solid graphite & $\begin{array}{l}\text { Hollow with } \\
\text { poison }\end{array}$ & Solid graphite \\
\hline \multicolumn{5}{|l|}{ Type of compact } \\
\hline $\begin{array}{l}\text { In upper } 9 \text { in. - } \\
\text { top } 3 \text { compacts }\end{array}$ & $A^{a}$ & A & $A$ & $D^{a}$ \\
\hline $\begin{array}{l}\text { In middle } 54 \text { in. - } \\
\text { middle } 18 \text { compacts }\end{array}$ & $B^{a}$ & $c^{a}$ & C & D \\
\hline $\begin{array}{l}\text { In lower } 27 \text { in. - } \\
\text { bottom } 9 \text { compacts }\end{array}$ & A & A & A & $\mathrm{D}$ \\
\hline $\begin{array}{l}\text { Number for nominal } \\
\text { core loading }\end{array}$ & 54 & 564 & 84 & 102 \\
\hline \multicolumn{5}{|l|}{ Metal content, $g$} \\
\hline Uranium & 249.6 & 249.6 & 249.6 & 140.7 \\
\hline Thorium & 1374 . & 1374 . & 1374 . & 2598. \\
\hline Boron & 0 & 0 & 18.31 & 0 \\
\hline Rhodium & 18.54 & 6.16 & 6.16 & 0 \\
\hline
\end{tabular}

$a_{\text {See Table }} 2.7$ for description of compacts. 


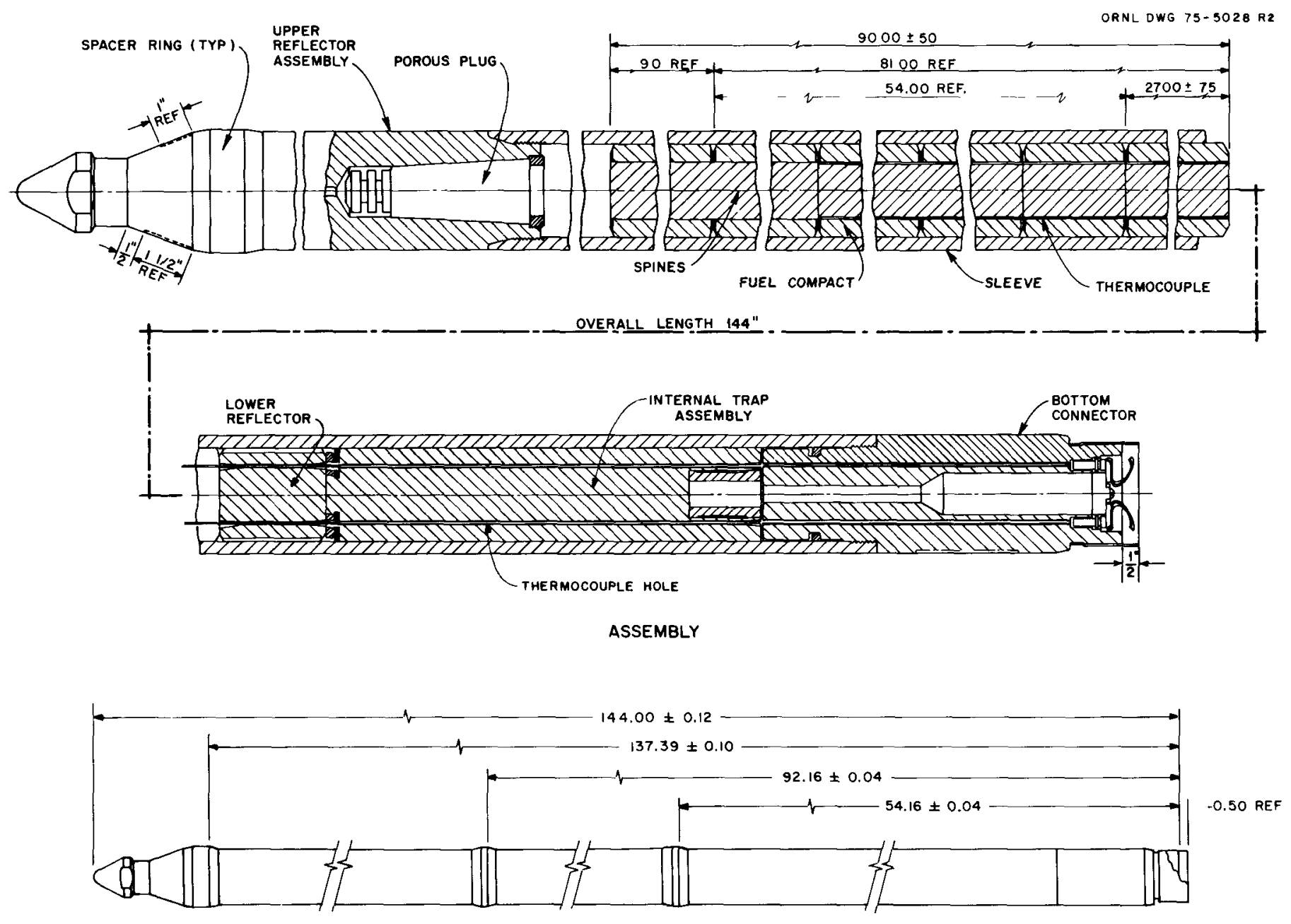

FUEL ELEMENT OUTLINE

Fig. 2.2. E06-OI driver fuel element assembly, Peach Bottom Core 2. 


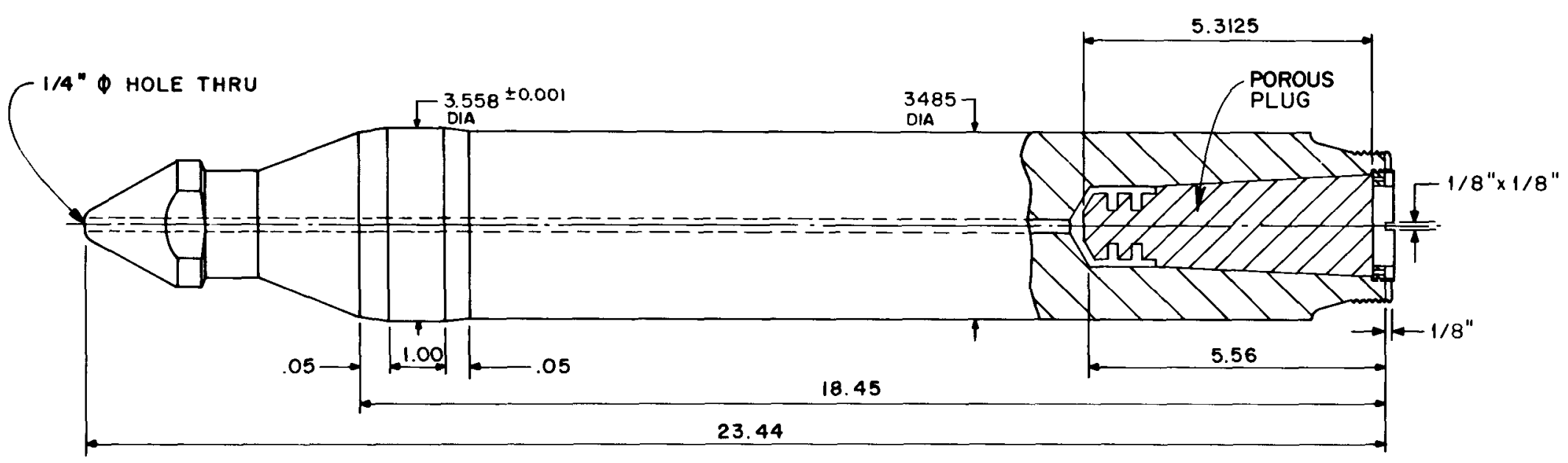

Fig. 2.3. Top reflector assembly. 


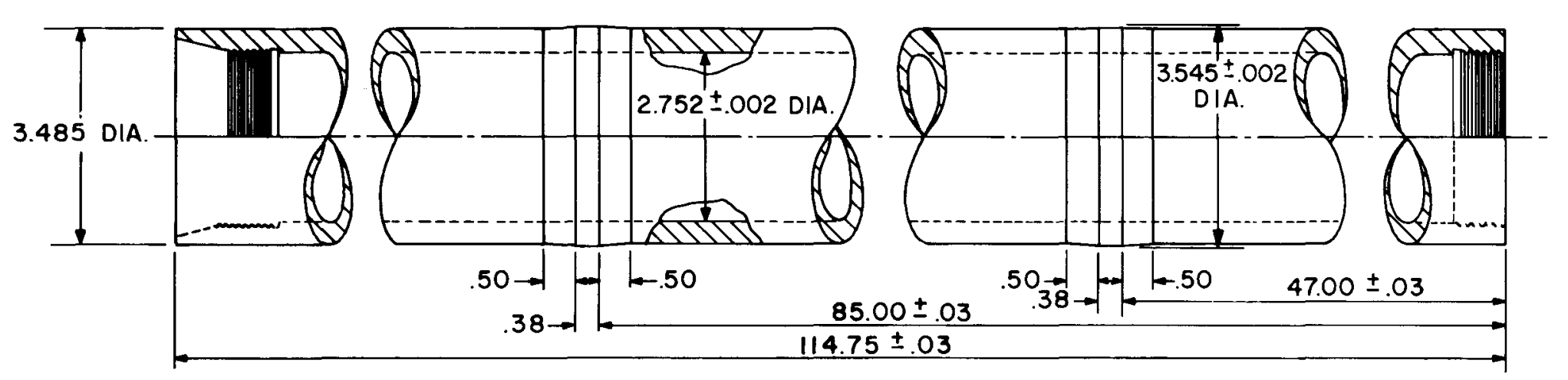

Fig. 2.4. Details of driver element sleeve, Peach Bottom Core 2. 
ORNL DWG 75-5032
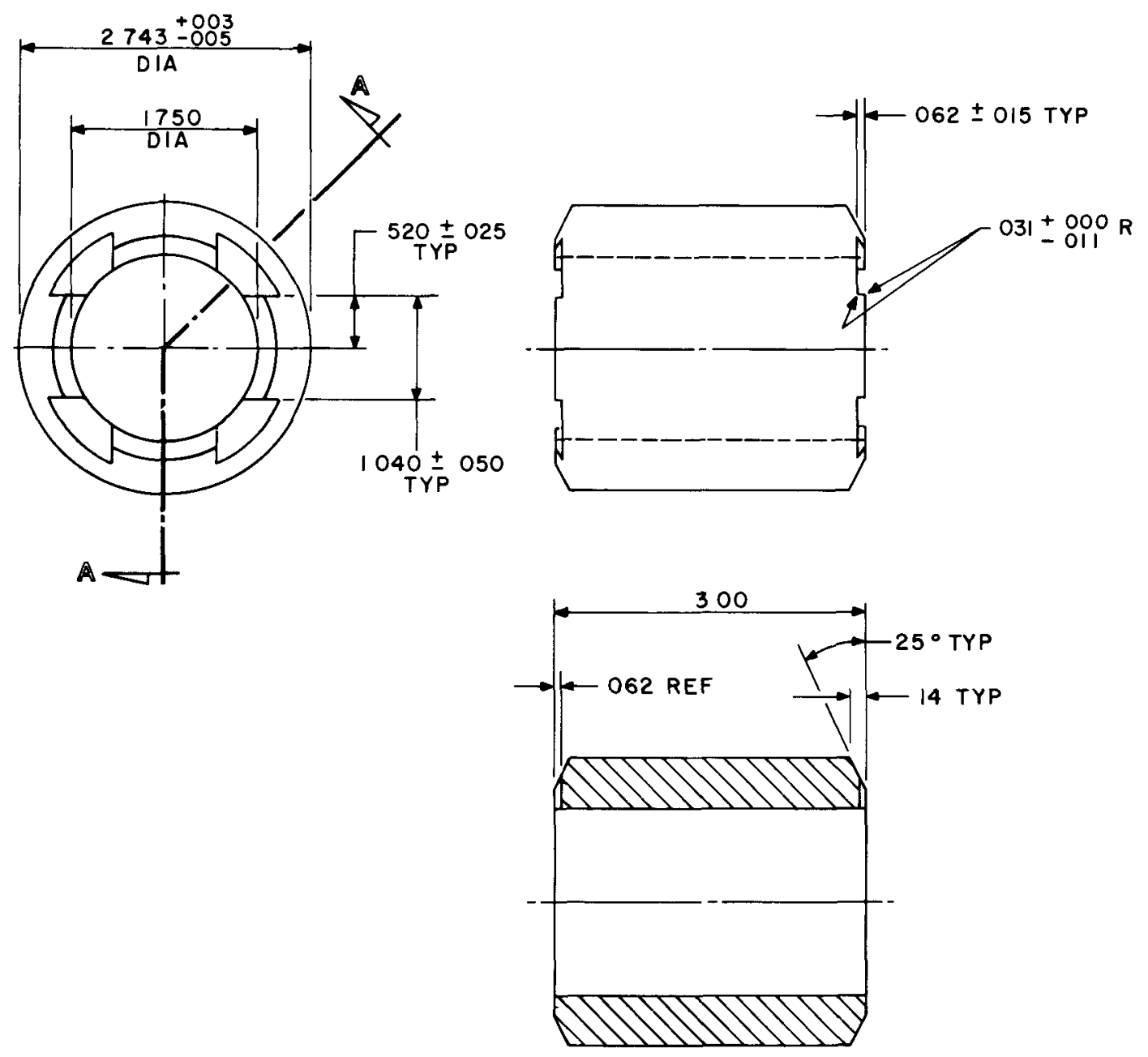

SECTION $A-A$

Fig. 2.5. Details of fuel compact, Peach Bottom Core 2. 
ORNL DWG 75-5029 RI
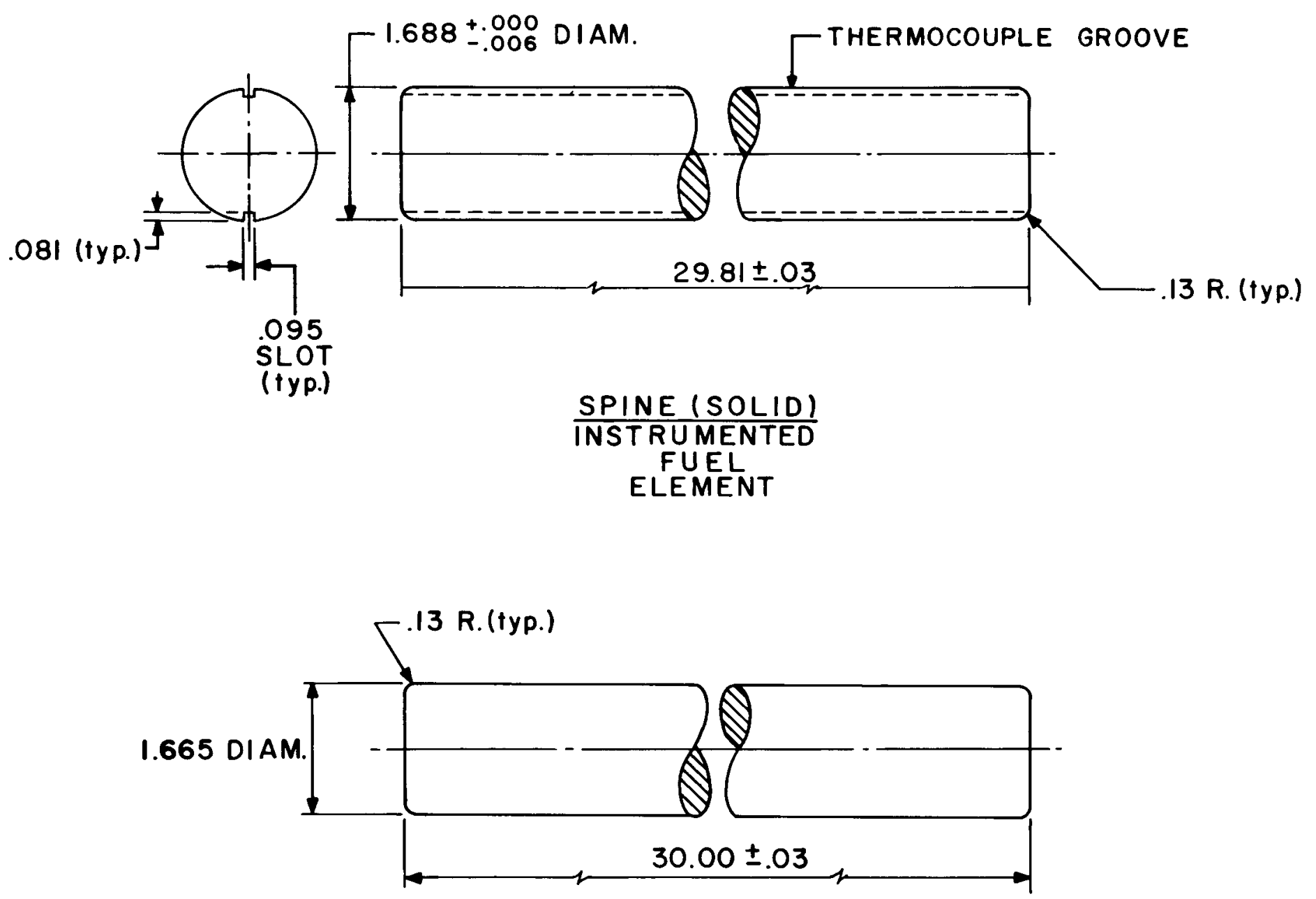

SPINE, SOLID

Fig. 2.6. Details of driver-element solid spines, Peach Bottom Core 2 . 
sleeve. * Purge gas flowed through the annular gaps between the fuel compacts and the sleeve, and between the fuel compacts and spine. The thickness of the gap between the fuel and sleeve before irradiation was about $0.0114 \mathrm{~cm}$ (0.0045 in.); correspondingly, the nominal gap between the fuel and spine was initially $0.079 \mathrm{~cm}$ (0.031 in.).

After leaving the fueled region, the purge gas flowed around the bottom reflector, through the fission product trap and screen, and finally through a center-line hole in the bottom connector. The fission product trap, shown in Fig. 2.7, was $31.9 \mathrm{~cm}$ (12.6 in.) long and contained 16 slots that were filled with activated charcoal granules. A steel filter screen below the trap prevented loss of the charcoal granules. The bottom connector, which was cemented to the sleeve, supported the element and connected the purge gas stream to the reactor's purge gas purification plant.

The element was equipped with two thermocouples located between the outer surface of the spine and the inner surface of the fuel compacts. The lower thermocouple, which was fabricated of Chromel-Alumel, was located $69 \mathrm{~cm}$ (27 in.) up from the bottom of the fueled region (at compact 9). The upper thermocouple, of tungsten-rhenium, was located $137 \mathrm{~cm}$ (54 in.) from the bottom of the fuel (at compact 18), near the region where maximum temperatures were expected. Details of the thermocouple installations and calibrations have been reported by Turner et al. 3

\subsection{Material Specifications}

\subsubsection{Graphite}

The types of graphite used in the various components of core 2 fuel elements as listed in the Peach Bottom FHSR, ${ }^{I}$ along with the manufacturer's name and code number denoting the purchase specifications of the graphite, are summarized in Table 2.2. Specifications of some critical properties of the graphite used for the sleeve and the spine were abstracted from those stipulated on the purchase orders and are presented in Tables 2.3 and 2.4.

\footnotetext{
* The text frequently specifies axial location by citing a compact number. The compacts are sequentially numbered from 1 to 30, beginning at the bottom and proceeding to the top of the core.
} 


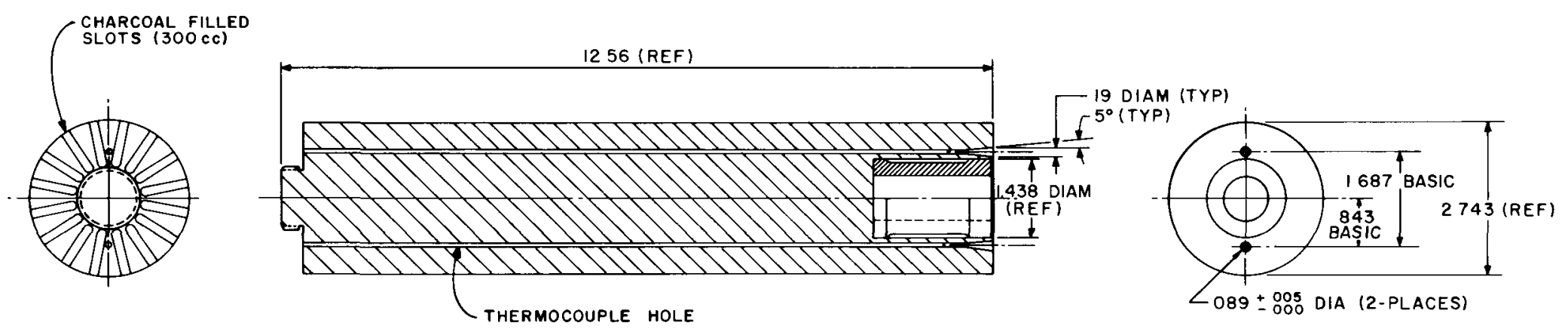

Fig. 2.7. Details of internal fission product trap. 
Table 2.2. Types of graphite used in Peach Bottom Core 2 fuel elements as specified by the Peach Bottom

Final Hazards Summary Report

Component of

fuel element
Type of graphite

Manufacturer

Top reflector

Top spine

Lower two spines with

thermocouple slots

sleeve

Internal trap

Bottom connector

HLM-85

7그-T

711 GSXY

HLM-85

HLM-85

GLCC $^{a}$

Speer

Speer

GICC

Speer

GICC
Purchase

specification number

PB-2-FO-IM

$\mathrm{PB}-2-\mathrm{FO}-6 \mathrm{M}$

$\mathrm{a}_{\text {Great Lakes Carbon Company. }}$

Table 2.3. Specifications of sleeve graphite of Peach Bottom Core 2 fuel elements ${ }^{a}$

\begin{tabular}{|c|c|}
\hline Property & Value \\
\hline Apparent bulk density, $\mathrm{g} / \mathrm{cm}^{3}$ & 1.80 minimum; 1.82 average \\
\hline $\begin{array}{l}\text { Specific electrical resistance, } \\
\text { ohm-in.2/in. }\end{array}$ & $28 \times 10^{-5}$ \\
\hline Maximum grain size, in. & 0.033 \\
\hline Thermal-neutron absorption cross section & $\begin{array}{l}\leq \text { the equivalent of } 5 \mathrm{ppm} \text { of } \\
\text { natural boron }\end{array}$ \\
\hline \multicolumn{2}{|l|}{ Chemical content, ppm } \\
\hline Iron & $\leq 100$ \\
\hline Sulfur & $\leq 100$ \\
\hline Titanium & $\leq 50$ \\
\hline Vanadium & $\leq 50$ \\
\hline Molybdenum & $\leq 100$ \\
\hline Boron & $\leq 5$ \\
\hline Total ash & $\leq 1000$ \\
\hline $\begin{array}{l}\text { Permeability to helium at }\langle\mathrm{p}>=0.5 \mathrm{~atm} \text {, } \\
\mathrm{cm}^{2} / \mathrm{sec}\end{array}$ & $\leq 3.0 \times 10^{-3}$ \\
\hline Regraphitization temperature, ${ }^{\circ} \mathrm{C}$ & $\geq 2800$ \\
\hline
\end{tabular}


Table 2.4. Specifications of spine graphite of Peach Bottom Core 2 fuel elements ${ }^{2}$

\begin{tabular}{|c|c|}
\hline Property & Value \\
\hline Density, $\mathrm{g} / \mathrm{cm}^{3}$ & 1.80 minimum; 1.84 mean \\
\hline $\begin{array}{l}\text { Thermal neutron absorption cross } \\
\text { section }\end{array}$ & $\begin{array}{l}\leq \text { the equivalent of } 5 \mathrm{ppm} \text { of natural } \\
\text { boron }\end{array}$ \\
\hline \multicolumn{2}{|l|}{ Chemical content, ppm } \\
\hline Boron & $\leq 5$ \\
\hline Molybdenum & $\leq 100$ \\
\hline Sulfur & $\leq 100$ \\
\hline Titanium & $\leq 50$ \\
\hline Iron & $\leq 100$ \\
\hline Vanadium & $\leq 50$ \\
\hline Total ash & $\leq 1000$ \\
\hline
\end{tabular}

Data obtained from ref. 2 .

Trace elements in a specimen of archive sleeve graphite were determined by neutron activation analysis, emission spectroscopy, and mass spectrometry in order to evaluate the effect of nuclide buildup in the sleeve due to neutron capture. These results are shown in Table 2.5.

\subsubsection{Fuel compacts}

The compacts used in Peach Bottom Core 2 contained BISO* fuel particles; that is, each particle had a uranium-thorium carbide kernel surrounded by a porous graphite buffer and an outer layer of pyrolytic graphite.

A summary of the specifications for Core 2 fuel particles is presented in Table 2.6. The "small" and "large" classifications of the particles simply denote that the particle kernels were more or less of two different sizes; the nominal values are given in the table.

*An acronym - Buffer Isotropic. 
Table 2.5. Trace-element concentrations in Peach Bottom fuel element graphite

(archive sleeve specimen)

\begin{tabular}{|c|c|c|c|c|c|}
\hline \multirow[b]{2}{*}{ Element } & \multicolumn{2}{|c|}{$\begin{array}{l}\text { Conc. (ppm) as } \\
\text { determined by: }\end{array}$} & \multirow[b]{2}{*}{ Element } & \multicolumn{2}{|c|}{$\begin{array}{l}\text { Conc. (ppm) as } \\
\text { determined by: }\end{array}$} \\
\hline & $\mathrm{NAA}^{\mathrm{a}}$ & $\mathrm{ES}^{\mathrm{b}}$ & & $\mathrm{NAA}^{\mathrm{a}}$ & $E S^{b}$ \\
\hline $\mathrm{Ag}$ & 0.002 & 0.02 & Iu & 0.007 & \\
\hline AI & 4.9 & 0.73 & $\mathrm{Mg}$ & $<8$ & 0.04 \\
\hline As & $<0.005$ & & $\mathrm{Mn}$ & 0.14 & $<0.009$ \\
\hline Au & 0.0012 & $<0.09$ & Mo & $<0.1$ & $<0.02$ \\
\hline$B$ & & 0.02 & $\mathrm{Na}$ & 15.1 & 0.18 \\
\hline $\mathrm{Ba}$ & $<0.2$ & $<0.02$ & $\mathrm{Nb}$ & & $<0.09$ \\
\hline $\mathrm{Br}$ & 0.03 & & $\mathrm{Nd}$ & $<0.5$ & \\
\hline $\mathrm{Be}$ & & $<0.002$ & $\mathrm{Ni}$ & $<4$ & $<0.04$ \\
\hline $\mathrm{Bi}$ & & $<0.04$ & $\mathrm{~Pb}$ & & 0.07 \\
\hline $\mathrm{Ca}$ & $7 \cdot 3$ & & $\mathrm{Pd}$ & & $<0.09$ \\
\hline $\mathrm{Cd}$ & $<0.2$ & $<0.09$ & $\mathrm{Rb}$ & & $<0.04$ \\
\hline $\mathrm{Ce}$ & 0.53 & & $\mathrm{Sb}$ & 0.0017 & $<0.04$ \\
\hline $\mathrm{Cl}$ & 15.7 & & $\mathrm{Sc}$ & 0.042 & \\
\hline $\mathrm{Co}$ & 0.079 & $<0.04$ & $\mathrm{Se}$ & 0.004 & \\
\hline $\mathrm{Cr}$ & 1.4 & $<0.04$ & Si & & 0.27 \\
\hline $\mathrm{Cs}$ & 0.0003 & $<0.09$ & Sn & & $<0.04$ \\
\hline $\mathrm{Cu}$ & 0.79 & 0.03 & $\mathrm{Sr}$ & $<0.5$ & \\
\hline Dy & 0.034 & & $\mathrm{Ta}$ & 0.003 & $<0.09$ \\
\hline Eu & 0.0002 & $<0.04$ & $\mathrm{~Tb}$ & 0.0057 & \\
\hline $\mathrm{Fe}$ & 7.4 & 0.36 & $T h$ & 0.058 & $0.14^{\mathrm{C}}$ \\
\hline $\mathrm{Ga}$ & & $<0.04$ & Ti & 9.2 & 0.73 \\
\hline $\mathrm{Ge}$ & & $<0.04$ & $\mathrm{U}$ & 0.052 & $0.08^{c}$ \\
\hline $\mathrm{Hf}$ & 0.014 & & $\mathrm{~V}$ & 1.8 & 0.18 \\
\hline $\mathrm{Hg}$ & 0.47 & $<0.04$ & W & 0.41 & $<0.09$ \\
\hline$I$ & $<0.01$ & & $\mathrm{Y}$ & & 0.04 \\
\hline $\mathrm{K}$ & 8.6 & 0.09 & $\mathrm{Yb}$ & 0.0056 & 0.004 \\
\hline $\mathrm{La}$ & 0.40 & 0.09 & Zn & 0.46 & 0.91 \\
\hline $\mathrm{Li}$ & & 0.004 & $\mathrm{Zr}$ & 0.48 & 0.18 \\
\hline
\end{tabular}

$\mathrm{a}_{\text {NIAA }}=$ neutron activation analysis.

$b_{E S}=$ electric arc emission spectroscopy.

Values determined by isotope dilution mass spectrometry. 
Table 2.6. Summary of specifications for BISO-coated particles for Core $2^{\mathrm{a}}$

\begin{tabular}{|c|c|c|c|c|}
\hline & \multicolumn{4}{|c|}{ Type of particle } \\
\hline & \multicolumn{2}{|c|}{ Low-thorium fissile } & \multicolumn{2}{|c|}{ High-thorium fissile } \\
\hline & Smal1 & Large & Smal1 & Large \\
\hline \multicolumn{5}{|l|}{ Kernel } \\
\hline $\begin{array}{l}\text { Nominal diameter, } \mu \mathrm{m} \\
\text { Th:U }\end{array}$ & $\begin{array}{l}300 \pm 50 \\
5.5: 1\end{array}$ & $\begin{array}{l}400 \pm 50 \\
5.5: I\end{array}$ & $\begin{array}{l}350 \pm 50 \\
18.5: 1\end{array}$ & $\begin{array}{l}450 \pm 50 \\
18.5: 1\end{array}$ \\
\hline \multicolumn{5}{|l|}{ Buffer } \\
\hline Thickness, $\mu \mathrm{m}$ & $\begin{aligned} 40 & +15 \\
& -5\end{aligned}$ & $\begin{array}{l}50+15 \\
-10\end{array}$ & $\begin{aligned} 40 & +15 \\
& -5\end{aligned}$ & $\begin{aligned} 50 & +15 \\
& -10\end{aligned}$ \\
\hline Density, $\mathrm{g} / \mathrm{cm}^{3}$ & $1.3+0.1$ & $1.3+0.1$ & 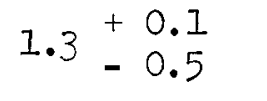 & $1.3+0.1$ \\
\hline $\begin{array}{l}\text { Isotropic PyC } \\
\text { thickness, } \mu \mathrm{m}\end{array}$ & $\begin{aligned} 60 & +15 \\
& -5\end{aligned}$ & $\begin{aligned} 85 & +15 \\
& -5\end{aligned}$ & $\begin{aligned} 45 & +15 \\
& -5\end{aligned}$ & $\begin{aligned} 60 & +15 \\
& -5\end{aligned}$ \\
\hline Density, $\mathrm{g} / \mathrm{cm}^{3}$ & $\begin{aligned} 1.80 & +0.15 \\
& -0.20\end{aligned}$ & $\begin{aligned} & 1.80+0.15 \\
&-0.20\end{aligned}$ & $\begin{array}{r}1.80+0.15 \\
-0.20\end{array}$ & $\begin{aligned} 1.80 & +0.15 \\
& -0.20\end{aligned}$ \\
\hline \multicolumn{5}{|l|}{$\mathrm{BAF}^{\mathrm{b}}$} \\
\hline$p \leq 1.95 \mathrm{~g} / \mathrm{cm}^{3}$ & $\leq 1.09$ & $\leq 1.09$ & $\leq 1.09$ & $\leq 1.09$ \\
\hline$\rho \leq 1.75 \mathrm{~g} / \mathrm{cm}^{3}$ & $\leq 1.12$ & $\leq 1.12$ & $\leq 1.12$ & $\leq 1.12$ \\
\hline $\begin{array}{l}\text { Total coating } \\
\text { thickness, } \mu \mathrm{m}\end{array}$ & $\begin{aligned} 100 & +20 \\
- & 10\end{aligned}$ & $\begin{aligned} 135 & +20 \\
- & 10\end{aligned}$ & $\begin{aligned} 85 & +20 \\
& -10\end{aligned}$ & $\begin{aligned} 110 & +20 \\
- & 10\end{aligned}$ \\
\hline
\end{tabular}

a Data obtained from ref. 1 .

$\mathrm{b}_{\mathrm{BAF}}=$ Bacon Anisotropy Factor; 1.0 denotes a completely isotropic coating. 
As noted in Table 2.I, the four types of driver fuel elements used. were made up from combinations of four types of fuel compacts. Initial heavy-metal loadings of each type of compact are given in Table 2.7.

Table 2.7. Nuclide compositions of the four types of fuel compacts of Peach Bottom Core 2

\begin{tabular}{lcccc}
\hline & \multicolumn{4}{c}{ Type of compact } \\
\cline { 2 - 5 } Nuclide & $\begin{array}{c}\mathrm{A}, \\
\text { Standard }\end{array}$ & $\begin{array}{c}\mathrm{B}, \\
\text { Heavy rhodium }\end{array}$ & Light rhodium & Heavy thorium \\
\hline \multirow{2}{*}{$232_{\text {Th }}$} & 45.8 & 45.8 & 45.8 & 86.6 \\
Uranium & 8.32 & 8.32 & 8.32 & 4.69 \\
Rhodium & 0 & 1.03 & 0.342 & 0 \\
\hline
\end{tabular}

The so-called "heavy thorium" compact was prepared from fuel particles containing a thorium:uranium ratio of 18.5:1. The other three types of compacts were prepared from particles having a thorium:uranium ratio of 5.5:I. The light-rhodium and the heavy-rhodium compacts were prepared by dispersing metallic rhodium powder in the matrix graphite. The standard compact contained no rhodium. One type of spine consisted of a solid graphite rod; a second type had a central axial cavity, 2.26 $\mathrm{cm}$ (0.89 in.) in diameter, that contained the burnable poison, zirconium diboride, dispersed in graphite pellets.

The fuel compacts consisted of hot-pressed, annular bodies containing BISO-coated particles in a carbonized pitch-graphite matrix. Except for the fuel particles, the raw materials and hot pressing procedure used to prepare Core 2 compacts were the same as those used to prepare Core I compacts. The dimensions of the compacts are shown in Fig. 2.5; their nuclide compositions are given in Table 2.7. The compacts were classified according to their composition as Type A (standard), Type B (heavy rhodium), Type C (light rhodium), and Type D (heavy thorium). The compositions of the different fuel elements in terms of nuclide content are presented in Table 2.1. The elements were classified as Type 1 (standard), Type 2 
(light rhodium), Type 3 (heavy rhodium), and Type 4 (heavy thorium), depending on the number and locations of the various types of compacts from which they were produced. Table 2.1 also gives the makeup of the elements in terms of types of compacts and spines and the locations of the different compacts within the element, along with the numbers of each type of element used in Core 2. In addition, it lists the nominal heavy-metal composition of each type of fuel element. Table 2.8 specifies the initial and end-of-life (EOL) heavy-metal contents of element E06-O1. A summary of the most important overall and internal physical characteristics of Peach Bottom Core 2 elements is given in Table 2.9.

Table 2.8. Heavy-metal contents of element E06-0I before and after irradiation ${ }^{a}$

\begin{tabular}{lcc}
\hline & \multicolumn{2}{c}{ Weight $(\mathrm{g})$} \\
\cline { 2 - 3 } Nuclide & Initially & On January 6, 1972 \\
\hline $232_{\mathrm{Th}}$ & 1373.8 & 1352.1 \\
$233_{\mathrm{Pa}}$ & 0.0 & 0.030 \\
$233_{\mathrm{U}}$ & 0.0 & 18.27 \\
$234_{\mathrm{U}}$ & 3.74 & 3.82 \\
$235_{\mathrm{U}}$ & 232.45 & 174.77 \\
$236_{\mathrm{U}}$ & 1.25 & 13.47 \\
$238_{\mathrm{U}}$ & 12.11 & 11.43 \\
\hline
\end{tabular}

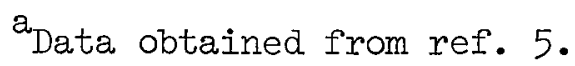

\subsection{Operating History - Power, Temperature, and Fluence}

The operation of EO6-OI was begun at startup of Core 2 on July 15, 1970, and terminated on January 7, 1972. An approximate power operating history is given in Table 2.10. From the fact that the full operating power of the reactor was $115.5 \mathrm{MW}(t)$, the data of this table indicate that element E06-01 experienced $384 \mathrm{EFPD}^{\prime}$ 's 
Table 2.9. Summary of fuel element parameters at beginning-of-life (Dimensions refer to ambient temperature)

Overall element:

Length, in.

Outside diameter, in.

Clearance between spacer rings, in.

(at operating temperature)

Helium permeability of sleeve, $\mathrm{cm}^{2} / \mathrm{sec}$

Tensile strength of sleeve, psi

$144.0+0.13$

$3.485 \mp 0.005$

0 to 0.010

$3 \times 10^{-3}$

2500

1.688

2.177

0.89

$30.0 \pm 0.03$

Length of each of three, in.

Compacts:

Outside diameter, in.

$2.743 \pm 0.003$

Inside diameter, in.

Length, in.

Compact volume, in. ${ }^{3}$

Cross-sectional area, in.
$1.750 \pm 0.005$

3.00

10.08

3.504

Purge:

Flow per element, Ib/hr

1.1

Percent flow between compacts and spines

$\sim 99$

Percent flow between compacts and sleeve

$\sim 1$

Cross-sectional area of gap between compacts and spines, in.2

0.228

Cross-sectional area of gap between compacts and sleeve, in.?

0.039

Total cross-sectiona'l area served by purge flow, in.? 
Table 2.10. Approximate power history of the

Peach Bottom Reactor during the operation of fuel element EO6-OI

\begin{tabular}{|c|c|}
\hline $\begin{array}{l}\text { Core power } \\
{[\mathrm{MW}(\mathrm{t})]}\end{array}$ & $\begin{array}{c}\text { Time at power } \\
\text { (days) }\end{array}$ \\
\hline 107.6 & 5 \\
\hline 107.6 & 25 \\
\hline 107.6 & 37 \\
\hline Shutdown & 4.5 \\
\hline 89.9 & 7.5 \\
\hline Shutdown & 5 \\
\hline 111.0 & 69 \\
\hline 111.0 & 69 \\
\hline 95.5 & 61 \\
\hline Shutdown & 80 \\
\hline 93.0 & 5 \\
\hline 93.0 & 25 \\
\hline 93.0 & 24 \\
\hline 93.0 & 10 \\
\hline 93.0 & 24 \\
\hline 93.0 & 24 \\
\hline Shutdown & 21 \\
\hline 104.5 & 40 \\
\hline 103.2 & 7 \\
\hline
\end{tabular}


Figure 2.8 presents the estimated trend of temperature with irradiation time at compact 9 for the fuel, sleeve, and coolant. ${ }^{5}$ End-of-life irradiation temperatures at the inner and outer surfaces of the compacts and sleeve and average thermal and fast neutron fluences experienced by the compacts, computed as a function of distance along the fueled region, 5 are shown in Fig. 2.9. As can be seen from these plots, the maximum compact temperature was expected approximately at compact 16. End-of-Iife temperatures at the inner diameter of the compacts ranged from about $878^{\circ} \mathrm{F}$ $\left(470^{\circ} \mathrm{C}\right.$ ) at the bottom of the core up to about $1897^{\circ} \mathrm{F}$ (1036 ${ }^{\circ} \mathrm{C}$ ) at compact 16 , and then decreased to about $1700^{\circ} \mathrm{F}\left(927^{\circ} \mathrm{C}\right)$ at the top of the core. The inner sleeve temperature, which was uniform over the central five or six compacts, ranged from a maximum of about $1418^{\circ} \mathrm{F}\left(770^{\circ} \mathrm{C}\right)$ at the top of the core to a minimum of $752^{\circ} \mathrm{F}\left(400^{\circ} \mathrm{C}\right)$ at the bottom of the core. The thermal fluence and fast fluences differed by about 10\%, with maximum values occurring near compact 13. Thermal-neutron fluences ranged from about $6 \times 10^{20}$ at the top and the bottom of the fuel to about $1.4 \times 10^{21}$ at compact 13 .

\section{EXAMIINATION PROCEDURES}

\section{I Visual and Photographic Examination}

The element was visually examined before and during dissection. Representative normal features and appearances were noted and photographed. AlI nonnormal features (e.g., cracks in compacts, graphite spallation, etc.) were photographically recorded.

\subsection{Examination of Thermocouples}

The thermocouples were tested for electrical continuity both before and after removal. Both thermocouples were clad in an inner and outer sheath. The tungsten-rhenium thermocouple was gamma scanned to obtain a relative distribution of neutron-induced activities which could serve as a measure of the relative distribution of neutron fluence over that region of the fuel element. 


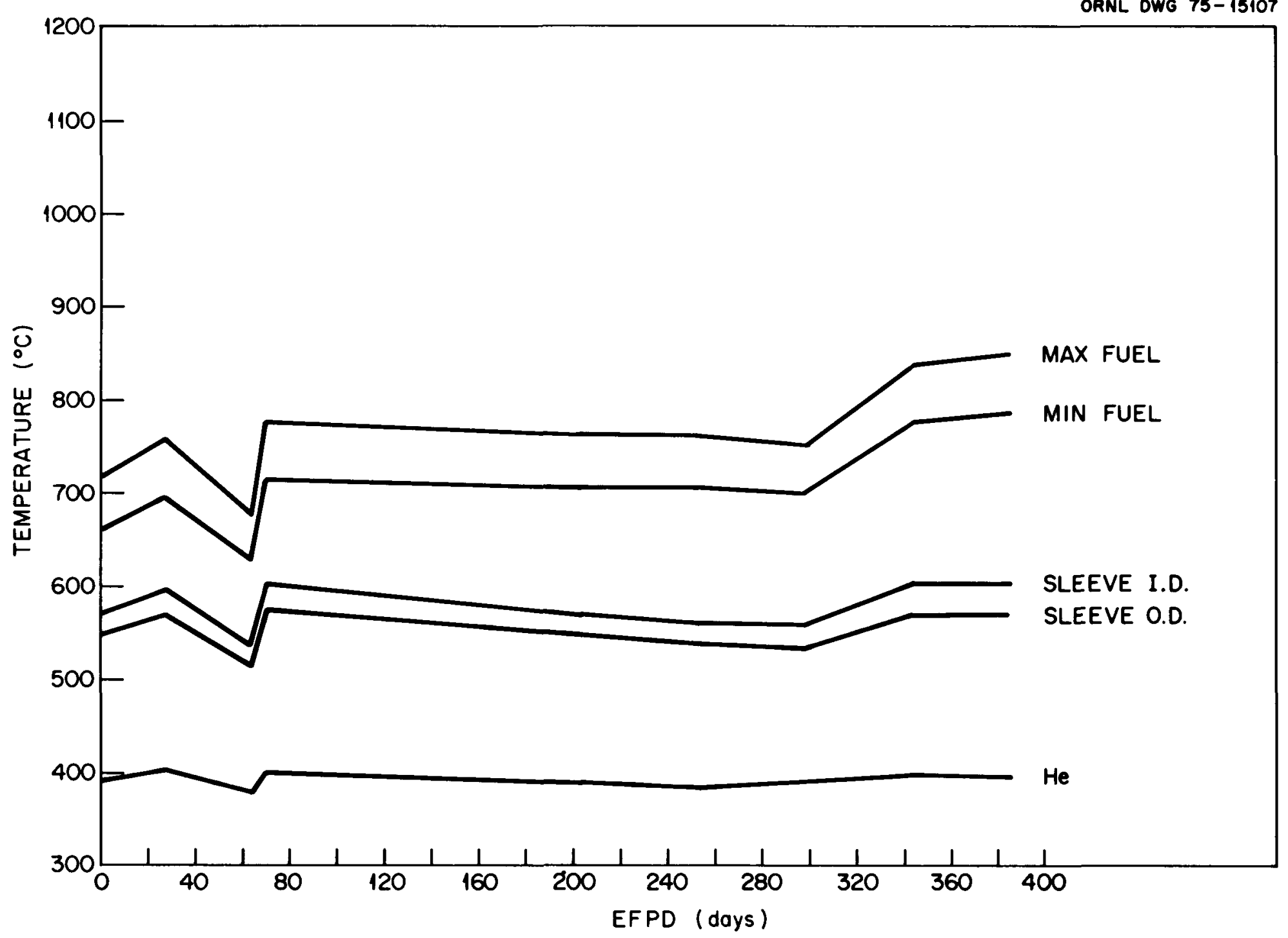

Fig. 2.8. Estimated temperatures at compact 9. 


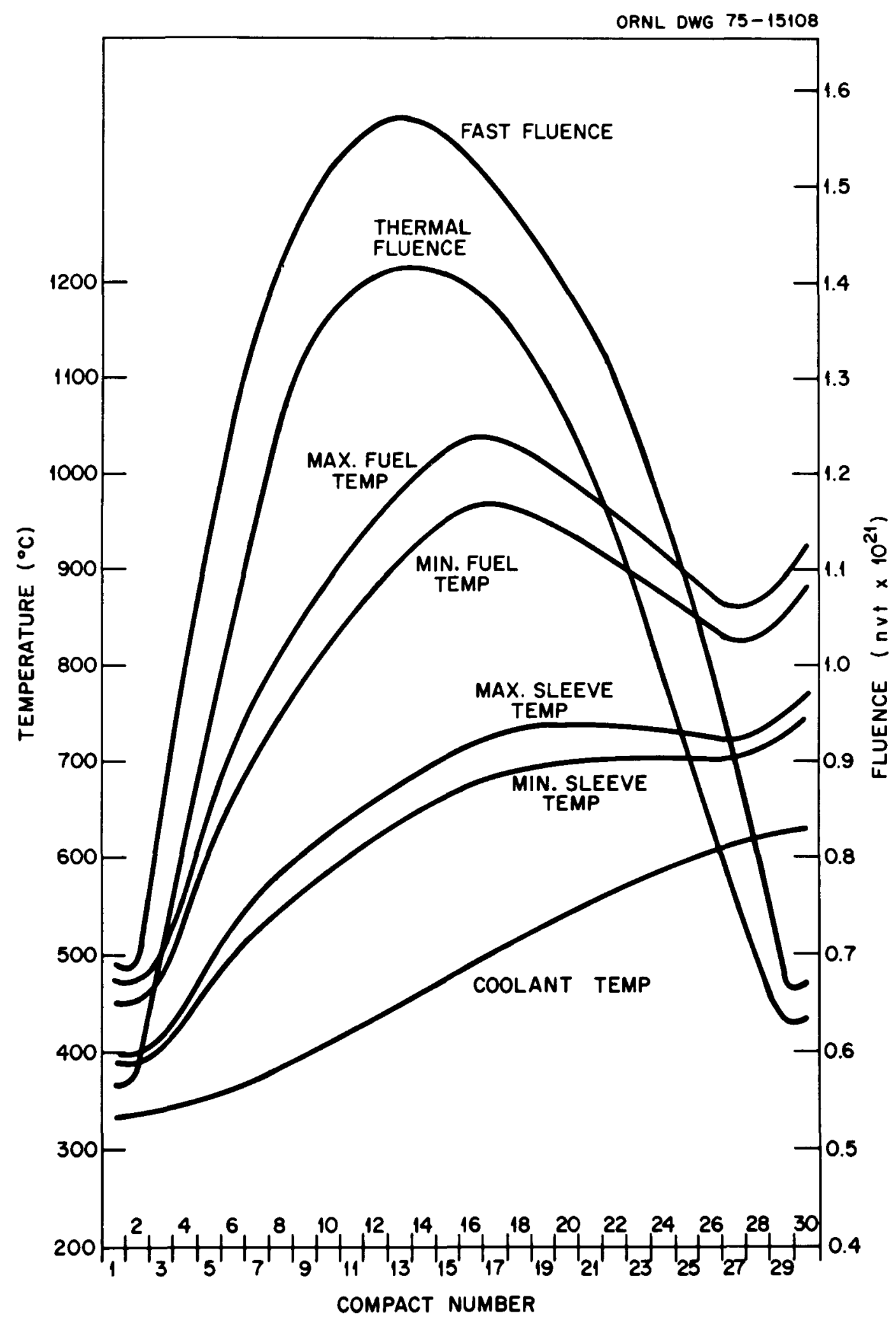

Fig. 2.9. Computed axial temperature and fluence profiles for E06-01 at end-of-life. (Data obtained from ref.6.) 


\subsection{Dissection of the Element}

The bottom reflector was removed by cutting through the element at a distance of $61.3 \mathrm{~cm}(24-1 / 8 \mathrm{in.})$ from the bottom of the element. Similarly, the top reflector was removed by cutting through the element at a distance $62.2 \mathrm{~cm}(24-1 / 2 \mathrm{in}$.) from the top of the element. These reflectors were placed in separate aluminum cans for gamma scanning, and their orientations within the cans were documented.

The spine pieces and fuel compacts were removed simultaneously by pushing on the bottom of the fuel with an aluminum rod. Separate containers were used for each spine piece and fuel compact; the orientations of the spines in their containers were documented. It was observed that a small amount of powder, which appeared to consist of graphite dust and broken fuel particles, preceded the removal of each fuel compact. This loose material was placed in the container for the compact.

The entire sleeve was placed in an aluminum container. The plastic sheath covering, in which the sleeve was kept during disassembly operations, was removed during loading into the container. The sleeve was then placed in a lead cask and transported to another building for gamma scanning and dissection for additional examination.

\subsection{Metrology of Fuel, Sleeve, Spine, and Top Reflector}

The following dimensional measurements were performed on element E06-01: The diameter of the top reflector was determined at three locations. The length, outer diameter, and wall thickness of compacts 3, 8, 13, 23, and 28 were measured using a dial-gauge comparator (see Fig. 3.1). Compact lengths were determined at four positions, each separated by $90^{\circ}$, on each of these six compacts. Outer diameter and wall thickness readings were taken in the middle and at both ends of the compact at two orientations separated by $90^{\circ}$. Micrometers were used to measure the diameters of those spines and sleeve pieces in which radial distributions of radionuclides were determined. 


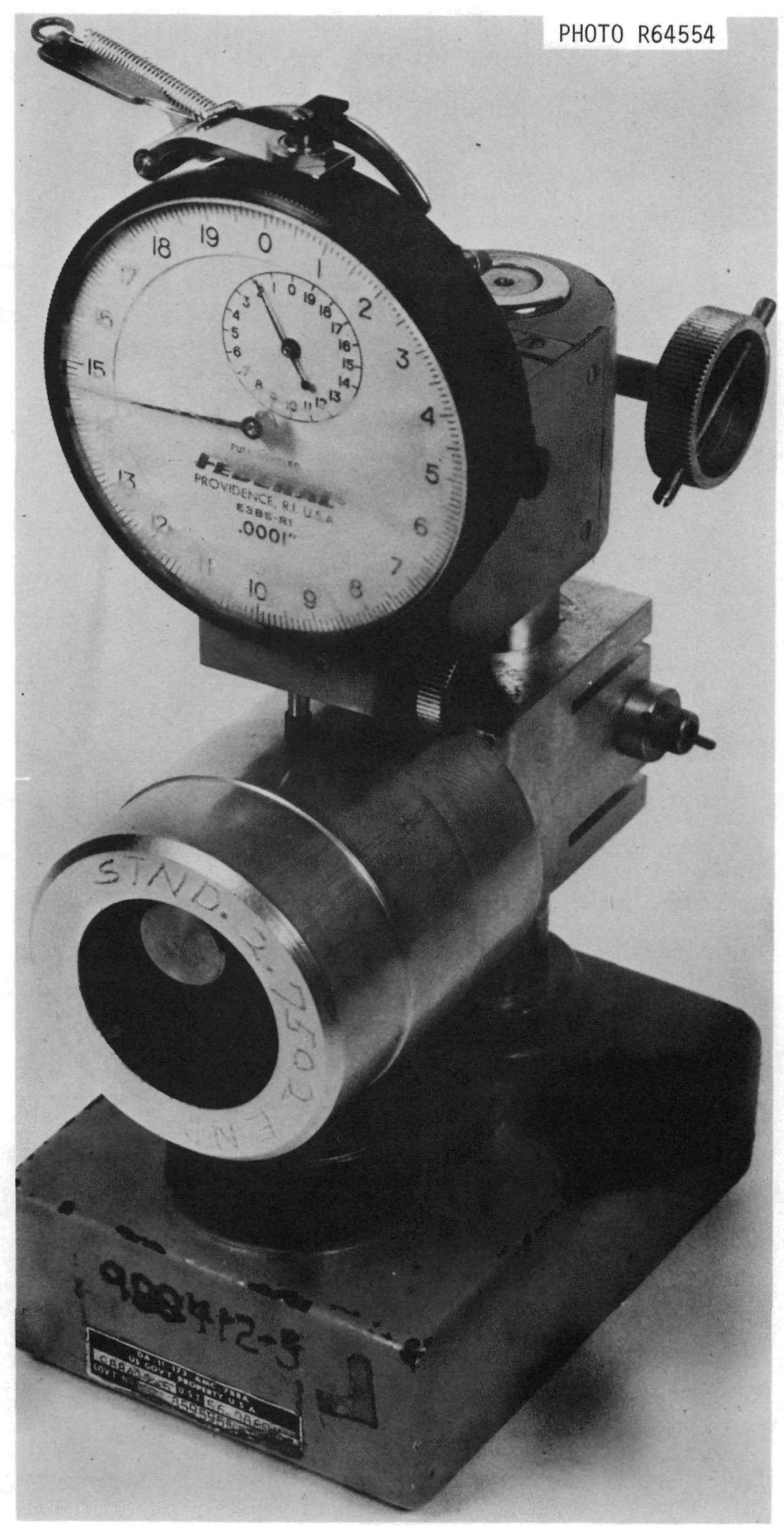

Fig. 3.1. Dial-gauge comparator for determining the dimensions of a compact. 


\subsection{Determination of Axial Distributions of Gamma-emitting Radionuclides}

\subsubsection{Top-reflector purge tube and porous plug}

The top reflector was cut into 12 cross-sectional pieces, and the graphite comprising the inner surface of the purge tube was removed by running a 11.1-mm (7/16-in.) drill through the tube of each piece. Since the diameter of the tube was $6.4 \mathrm{~mm}$ (1/4 in.), this procedure removed a thickness of $2.4 \mathrm{~mm}$ (3/32 in.) of graphite from the surface. The graphite removed from each piece was collected separately and measured by gamma spectroscopy to determine the gamma-emitting radionuclides. Beta-emitting radionuclides were not determined in these samples. The lengths and locations of each piece cut from the reflector, along with measured results, are given in Table 4.6 (see sect. 4.2).

The portion of the top reflector containing the porous plug was cut into six cross-sectional pieces, and each piece was analyzed by gamma spectroscopy to determine the concentrations of gamma emitters. Table 4.7 (see sect. 4.2) gives the location and length of each piece, as well as the axial distributions of fission products. No attempt was made to remove the structural graphite surrounding the plug.

\subsubsection{Fuel compacts}

The fuel compacts, each in a separate container, were transferred to a hot cell in which garma spectra could be obtained using a collimator assembly that penetrated a wall of the hot cell. The collimator consisted of a lead cylinder $43.2 \mathrm{~cm}$ (17 in.) long with a $0.32-\mathrm{cm}$ (I/8-in.) axial hole. Gamma spectra were acquired by allowing gamma rays from a restricted area on a compact to traverse the collimator tube and fall on a $\mathrm{Ge}(\mathrm{Li})$ detector outside the hot cell. Each compact was placed about 30.5 (12 in.) from the face of the collimator with the horizontal axis situated normal to the collimator's axis. The first compact was centered over the collimator by vertical and horizontal movements which served to define the boundaries of the compact. It was then moved to the center between these determined boundaries. Subsequent compacts were 
placed in the same position as the first. The size of the collimator bore was chosen to maximize the subtended area on the compacts $[\sim 1.3-\mathrm{cm}-$ diam area] within the count-rate limitations of the pulse-height analyzer system. No absorber was needed to reduce the count rates. The distance from the rear face of the collimator to the detector was about $5 \mathrm{ft}$. All of the compacts were counted during the last week of February 1973. Gamma spectra were stored on punched paper tape and processed at a later date after the counting efficiencies of the detector-collimator assembly had been determined.

\subsubsection{Sleeve, spine, and fission product trap}

The axial distributions of gamma emitters in the sleeve, spine, and fission product trap were determined via scanning measurements made by using a gamma-ray collimator which is described in sect. 3.10.2. Gammaray spectra of the sleeve and spine were acquired at locations that had been adjacent to the midpoints of fuel compacts. The collimators were formed using lead bricks with slits about $6 \mathrm{~mm}$ (1/4 in.) wide. The lengths of sleeve and spine subtended by the collimators were about $13 \mathrm{~mm}$ ( $1 / 2$ in.). In the case of the sleeve, the collimator was formed between two lead casks and the sleeve was moved by the collimator by pushing it from one cask to the other. Spine pieces were gamma scanned by moving them over a slit formed in a lead brick wall.

The axial distributions of gamma emitters in the fission product trap were determined in a manner similar to the method used for the spine. Gamma spectra were acquired at $2.5-\mathrm{cm}$ (1-in.) intervals using a collimator slit that subtended a length of $2.5 \mathrm{~cm}$ ( 1 in.) along the trap.

\subsection{Measurement of Radionuclides in Sections Cut from Sleeve and spine}

Thin cross-sectional pieces were cut from the sleeve and spines at positions adjacent to fuel compacts 2, 4, 7, 10, 15, 18, 22, and 26. These pieces were analyzed, first, by gamma spectroscopy for gamma emitters on an accurately calibrated $\mathrm{Ge}(\mathrm{Li}$ ) detector and, then, by radiochemical 
methods for ${ }^{90} \mathrm{Sr}$ and ${ }^{3} \mathrm{H}$. Results obtained for the gamma emitters were used to obtain counting efficiencies of the detector-collimator assemblies (see sect. 3.10).

The radiochemical procedure consisted of burning the graphite in a stream of water-saturated oxygen. The gaseous effluent was passed over heated copper oxide to ensure complete conversion to tritium oxide.

The tritiated water was collected in a liquid nitrogen trap, and the tritium concentrations were measured by liquid scintillation counting. The ash left from the graphite was dissolved, and ${ }^{90} \mathrm{Sr}$ was separated from other fission products by standard radiochemical methods. The ${ }^{90} \mathrm{Sr}$ was then determined by beta counting techniques.

\subsection{Measurement of Radial Distributions of Radionuclides} in Top Reflector, Sleeve, and Spine

Radial distributions of gamma-emitting radionuclides, ${ }^{90}{ }_{\mathrm{Sr}}$, and ${ }^{3} \mathrm{H}$ were measured at three axial locations in the sleeve and spine adjacent to fuel compacts 7, 16, and 26. Additionally, distributions of gamma emitters were determined at three locations in the top reflector (i.e., at 22,30 , and $38 \mathrm{~cm}$ from the top of the element). Tritium concentrations were measured in specimens taken from the $22-\mathrm{cm}$ location. The procedure used in all radial sampling was to mill a $13-\mathrm{mm}-$ long (1/2-in.long) graphite section with a lathe from the outside toward the center. Dust samples, collected in small plastic vials, were analyzed for gamma emitters, ${ }^{3} \mathrm{H}$, and $90_{\mathrm{Sr}}$.

\subsection{Metallographic and Microprobe Examination of Fuel Particles}

An estimate of the fuel particle failure fraction was made by metallographic examination. Two cross-sectional planes of compact 17 were polished, photographed, and counted for broken particles. A few particles were also subjected to microprobe examination in an attempt to detect cesium in the buffer zone. 


\subsection{FTMA ${ }^{*}$ Determinations}

FIMA determinations** on samples of fuel particles were made using a method that is similar to the one developed by Buzzelli and $\mathrm{Smith}^{6}$ and is based on the measurement of elemental zirconium, uranium, and thorium concentrations. In this method, the number of fissions that have occurred is computed from the observed zirconium content. Zirconium was chosen because it meets the requirements necessary for a good burnup monitor; namely, it

(1) does not migrate in fuel (i.e., it does not escape from the particles at the operating temperatures of HTGR's),

(2) has high and nearly equal fission yields from both $235_{U}$ and $233_{U}$,

(3) does not transmute significantly by neutron capture,

(4) is easily and accurately measured by standard analytical chemistry procedures, and

(5) does not suffer significantly from contamination problems (i.e., zirconium in borosilicate and quartzware).

The steps used to determine FIMA for E06-OI fuel were as follows: Three 3/8-in.-diam fuel specimens were core drilled from compacts 18 and 27 to give a total sample size of about $3 \mathrm{~g}$ per compact. The coredrilled specimens were deconsolidated by anodic oxidation in a nitric acid solution containing a small amount of perchloric acid. The particles acquired from each compact were placed in separate containers and mixed thoroughly. Three samples, each consisting of two particles, were selected from each of the two batches of particles so that a triplicate analysis could be made for each fuel compact.

Initially, we investigated the technique used by Buzzelli, in which particles are crushed and dissolved in nitric acid in special quartzware.

\footnotetext{
*FIMA = Eission of Initial Heavy Metal Atoms.

** Measurements were made by J. I. Botts, of the ORNL Analytical Chemistry Division.
} 
However, the analyses obtained with this technique were never satisfactory; the results for zirconium were thought to be too high, and the thorium values were apparently too low. A new dissolution procedure was then adopted whereby the particles were heated for 24 to $36 \mathrm{hr}$ in nitric acid in a high-pressure reaction chamber lined with Teflon. The reaction temperatures used were near $270^{\circ} \mathrm{C}$. After the particles had been dissolved, the solution volume was adjusted to $10 \mathrm{ml}$ and a small aliquot was taken for thorium and uranium determinations by isotope dilution mass spectrometery (IDMS). These determinations were made without chemical separations. The remainder of the solution was used to determine zirconium, thorium, and uranium by spectrophotometric methods. Zirconium was separated from uranium, thorium, and other fission products by absorption on Dowex IX8 anion exchange resin from a $12 \mathrm{M} H C I$ solution. Since thorium does not form an anionic chloride complex, it did not absorb and was thus eluted in this step. The zirconium was eluted with $6 \mathrm{M} \mathrm{HCl}$; the uranium, which remained on the resin, was subsequently eluted with $0.1 \mathrm{M} \mathrm{HCl}$. The solution containing the zirconium was then made $9 \underline{\mathrm{M}}$ in $\mathrm{HCl}$, and arsenazo III was added to form a zirconium-arsenazo III complex which may be measured spectrophotometrically at $665 \mathrm{~nm}$. Following this step, the solution containing the uranium was made $4 \underline{\mathrm{M}}$ in HCl and passed through a lead reductor to reduce the uranium to U(IV). The U(IV)-arsenazo III complex, which develops in 4 M HCl, was measured at $665 \mathrm{~nm}$.

\subsection{Gamma Spectroscopy}

\subsubsection{Equipment}

AlI garma spectra of EO6-OI components were acquired and analyzed on a Nuclear Data 4410 pulse-height analyzer system based on a Nuclear Data 812 computer with a 16K, 12-bit word memory. The organization and operation of this system have been discussed by Dyer and McDaniel. ${ }^{7}$ The detector used was a Nuclear Diode Ge(Li) type having a resolution of 2.3 $\mathrm{keV}$ and a counting efficiency of $4.6 \%$ of a 3 - by 3 -in. NaI detector.*

\footnotetext{
* These detector specifications pertain to the photopeak of the $1332-\mathrm{keV}$ Iine of $60_{\mathrm{Co}}$.
} 


\subsubsection{Counting procedures and counting efficiency calibrations}

Gamma spectra were acquired by either of two means: (1) with simple counting geometries in which small samples were placed at a fixed distance from a detector with no intervening absorbers, or (2) with gamma scanning measurements in which a collimator was used to localize the gamma-emitting region on a fuel-element component. Samples of fuel compacts, sleeve, spines, and upper reflector were removed by cutting or drilling and counted in simple geometry. Axial distributions of radionuclides in fuel compacts, sleeve, spines, and fission product trap were determined by gamma scanning with a collimator arrangement.

The counting efficiencies for simple counting geometries, defined as the ratio of counts measured to photons emitted, were measured in the conventional manner. Two types of standard sources were used: sources produced and sold by the U.S. National Bureau of Standards, the International Atomic Energy Agency, and Amersham Radiochemical Center; and secondary standards of ${ }^{137} \mathrm{Cs},{ }^{60} \mathrm{Co}$, and ${ }^{226} \mathrm{Ra}$. The primary standards consisted of the sources ${ }^{241} \mathrm{Am},{ }^{57} \mathrm{Co},{ }^{203} \mathrm{Hg},{ }^{139} \mathrm{Ce},{ }^{113} \mathrm{Sn},{ }^{109} \mathrm{Cd},{ }^{22} \mathrm{Na},{ }^{85} \mathrm{Sr},{ }^{137} \mathrm{Cs}$, ${ }^{54} \mathrm{Mn},{ }^{60} \mathrm{Co}$, and ${ }^{88} \mathrm{Y}$. Both the primary and the secondary standards closely approximated point sources and had windows (covers) that resulted in self-shielding factors of $4 \%$ or less. The primary standards ranged in activity levels from $I$ to $15 \mu \mathrm{Ci}$ and served to calibrate the detector distances up to about $50 \mathrm{~cm}$.

A set of secondary standards of ${ }^{137} \mathrm{Cs}$ and ${ }^{226} \mathrm{Ra}$, ranging from 10 to $300 \mu \mathrm{Ci}$, was prepared to calibrate efficiencies for source-to-detector distances up to about $300 \mathrm{~cm}$. The ${ }^{137} \mathrm{Cs}$ standards were prepared from a solution which had been previously standardized by comparison with a known quantity of a primary ${ }^{137} \mathrm{Cs}$ standard. The ${ }^{226} \mathrm{Ra}$ standards were prepared by wrapping small particles of $\mathrm{RaSO}_{4}$ in thin aluminum foil and then potting in epoxy resin. These sources were then calibrated relative to the primary and secondary ${ }^{137}$ Cs standards.

Two additional standards, consisting of about $12 \mathrm{mCi}$ of ${ }^{137} \mathrm{Cs}$ and ${ }^{60} \mathrm{Co}$ encapsulated in thin-walled stainless steel ampules, were standardized with a calibrated gamma ionization chamber. These were used to determine the counting efficiency for core-drilled specimens from E06-01 fuel compacts. 
For a particular gamma energy and a specific simple counting geometry, the counting efficiency, EF, is the proportionality constant relating the net count rate, counts/sec, in the photopeak and the photon emission rate, $\gamma / \mathrm{sec}$, of the source; that is,

$$
E F=\frac{(\text { count } / \mathrm{sec})}{(\gamma / \mathrm{sec})}
$$

A complete counting efficiency response vs energy can be obtained by measuring several standard sources (e.g., the set of primary standards listed above) with a wide range of gamma energies.

Counting efficiencies for all gamma-scanning measurements were derived by determining the photon emission rates per gram for each radionuclide from a small specimen cut from the fuel element. These rates were determined by comparison with a secondary standard employing simple geometry and were corrected for decay to the times that the gamma scanning measurements were made. EF values for the gamma scanning measurements were computed from the expression

$$
\mathrm{EF}=\frac{(\text { count } s / \mathrm{sec})}{(\gamma / \mathrm{g} \cdot \mathrm{sec})}
$$

Counting efficiencies were derived for the fission product trap by preparing a solution with a measured amount of ${ }^{140} \mathrm{La}$ in a plastic container having the same diameter as the trap. This standard was then counted under conditions that provided the same configuration of source, collimator, and detector as was used for the trap. Counting efficiencies were specified on a volume basis from the relation

$$
\mathrm{EF}=\frac{(\text { counts } / \mathrm{sec})}{\left(\gamma / \mathrm{cm}^{3} \cdot \mathrm{sec}\right)} \text {. }
$$

\subsubsection{Analyses of gamma spectra}

All data relative to gamma spectra were reduced to microcuries per gram of fuel element component (or per cubic centimeter for the case of the fission product trap) by the relation 


$$
\left(\frac{\mu \mathrm{Ci}}{g}\right)_{i j}=\frac{(\text { counts } / \mathrm{sec})_{i j} \cdot \mathrm{e}^{\lambda_{i} t}}{\mathrm{EF} \cdot \mathrm{B}_{i} \cdot \mathrm{F} \cdot 3 \cdot \mathrm{TE} 4},
$$

where $j$ denotes a particular gamma ray from nuclide $i$ that emits $B_{i}$ photons per disintegration. The quantity $e^{\lambda_{i} t}$ corrects the result for decay from the time of reactor shutdown to the time of the measurement. F is an empirically measured correction factor which takes into account coincident counting losses in the amplifier, and the numerical factor in the denominator converts counts per second to microcuries. The quantity $B_{i}$, usually called the gamma branching ratio, was taken from Dyer and Bate 8 for all radionuclides measured.

The computer programs used to acquire and analyze gamma spectra and convert the count-rate results to microcuries per unit weight of sample are described by Dyer and McDaniel. ${ }^{7}$ Briefly, the programs function as follows: A search is made to find the peaks and the channel in which a peak is centered. (the peak centroid). The net counts in the peak is then derived by using the difference in the gross counts, GC, in a region of channels enclosing the peak and the counts in a linear base line under the peak, $\mathrm{BL}$; that is, the

$$
\text { net count rate } / g=\frac{(G C-B L)}{T_{L} \cdot \operatorname{mass}} \text {, }
$$

where $\mathbb{T}_{L}$ is the live time (in seconds) of the counting period.

The energy, E, of the peak is computed from the linear relation

$$
\mathrm{E}(\mathrm{keV})=\mathrm{E}_{0}+\mathrm{DE} \cdot \mathrm{C},
$$

where $E_{\circ}$ is the energy intercept (energy of channel zero), DE is the slope in $\mathrm{keV}$ per channel, and $C$ is the peak centroid expressed as channels.

The value of $\mathrm{EF}$ is computed from the energy using an empirical relation of the form

$$
E F=\exp \left(C 1+C 2 \ln E+C 3 \ln ^{2} E+C 4 \ln ^{3} E\right),
$$

where the constants are determined using results from the measurements on radionuclide standard samples. The photon emission rate per unit sample 
weight for a particular photopeak is then obtained by dividing the observed count rate by the calculated efficiency.

The computer program used to acquire the spectra makes the above computations and produces a list of centroids, energies, count rates, and photon emission rates. The "count-rate table" is also punched on paper tape, which is then used by another program to identify the radionuclides responsible for the peaks. Radionuclides are identified by comparing the energies of peaks found in a spectrum with those in a nuclide library. When the energies match within a preset value of about $2 \mathrm{keV}$, results are computed in microcuries per unit sample mass and presented in tabular form.

3.10.4 Mutual interferences of the measurements of gamma rays

Gamma spectrometric analyses of some radionuclides in combination with others are made difficult (or impossible) due to overlapping photopeaks. The extent of such mutual interference depends on the difference between gamma-ray energies and the detector resolution, defined as the full width of a photopeak at one-half its maximum height (FWHM). If the intensities of two gamma rays are similar and their energies differ by more than approximately 3 FWHM, insignificant peak overlapping occurs. However, for energy differences less than 1 FWHM, photopeaks tend to merge into a single, broadened peak. Intermediate situations occur when peak energies differ between 1 and 3 FWHM. Although the photopeaks overlap in these cases, the presence of two peaks is easily detected and the areas of the individual peaks are readily measured.

In this work only two significant interferences were encountered, namely, an interference of ${ }^{137} \mathrm{Cs}$ by ${ }^{110 \mathrm{~m}_{\mathrm{Ag}}}$ and of ${ }^{95} \mathrm{Zr}$ by ${ }^{154} \mathrm{Eu}$. The most intense gamma ray of ${ }^{110 \mathrm{~m}} \mathrm{Ag}$ has an energy of $658 \mathrm{keV}$, which is about $4 \mathrm{keV}$ less than the single $662-\mathrm{keV}$ gamma ray of ${ }^{137} \mathrm{Cs}$. This difference is considerably larger than the FWHM (2.3 keV) of the detector used; thus, in most cases, the two photopeaks were sufficiently resolved to be measured. In a few gamma spectra of sleeve and spine sections, however, the two peaks were not resolved and $110 \mathrm{~m}$ Ag interfered with the measurements of ${ }^{137} \mathrm{Cs}$. 
(Cesium-137 does not interfere with the measurement of ${ }^{110 \mathrm{~m}} \mathrm{Ag}$ since ${ }^{110 \mathrm{~m}} \mathrm{Ag}$ has other gamma rays that are free of interference.) This interference was corrected by measuring both the total count rate of the overlapping peaks and the disintegration rate of ${ }^{110 \mathrm{~m}_{\mathrm{Ag}}}$ using its garma rays that were free of interferences. The count rate of the $658 \mathrm{keV}$ photopeak of $17 \mathrm{~m}_{\mathrm{Ag}}$ was then computed and subtracted from the total count rate of the overlapping peaks. The difference is the count rate due to ${ }^{137} \mathrm{Cs}$. The interference of the measurement of ${ }^{95} \mathrm{Zr}$ by ${ }^{154} \mathrm{Eu}$ occurs because ${ }^{154} \mathrm{Eu}$ emits ganma rays with energies almost identical to those of the two gamma rays of ${ }^{95} \mathrm{Zr}$ (724 and $\left.756 \mathrm{keV}\right)$. However, since ${ }^{154} \mathrm{Eu}$ has other interference-free gamma rays, corrections can be made in a manner similar

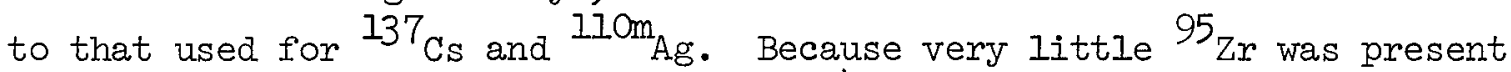
in the spine and sleeve of EO6-0I and ${ }^{154} \mathrm{Eu}$ was formed in the graphite by neutron capture reactions of the ${ }^{153_{\mathrm{Eu}}}$ impurity in the graphite, this interference was significant in most of the spectra of the spine and sleeve. Therefore, corrections were made for all spectra of the spine and sleeve. Because the amounts of ${ }^{110 \mathrm{~m}} \mathrm{Ag}$ and ${ }^{154} \mathrm{Eu}$ in the fuel were very low, no interferences occurred in the spectra of the fuel.

\section{RESUITS AND DISCUSSION}

\section{I External Examinations and Metrology}

No significant postirradiation abnormalities of the element were observed. Two marks that ran the entire length of the element were present on opposite sides of the element but appeared to be only on the surface. These marks, of unknown cause, are clearly shown in photographs of the top, midale, and bottom sections of the element in Figs. 4.1-4.3.

Results of dimensional measurements made on the fuel compacts as described in sect. 3.9 are presented in Tables 4.1-4.3. The inner diameters of the compacts (see Table 4.2) were obtained by subtracting the sum of the wall thicknesses measured on opposite sides of the compacts from the measured outer diameters given in the table. 


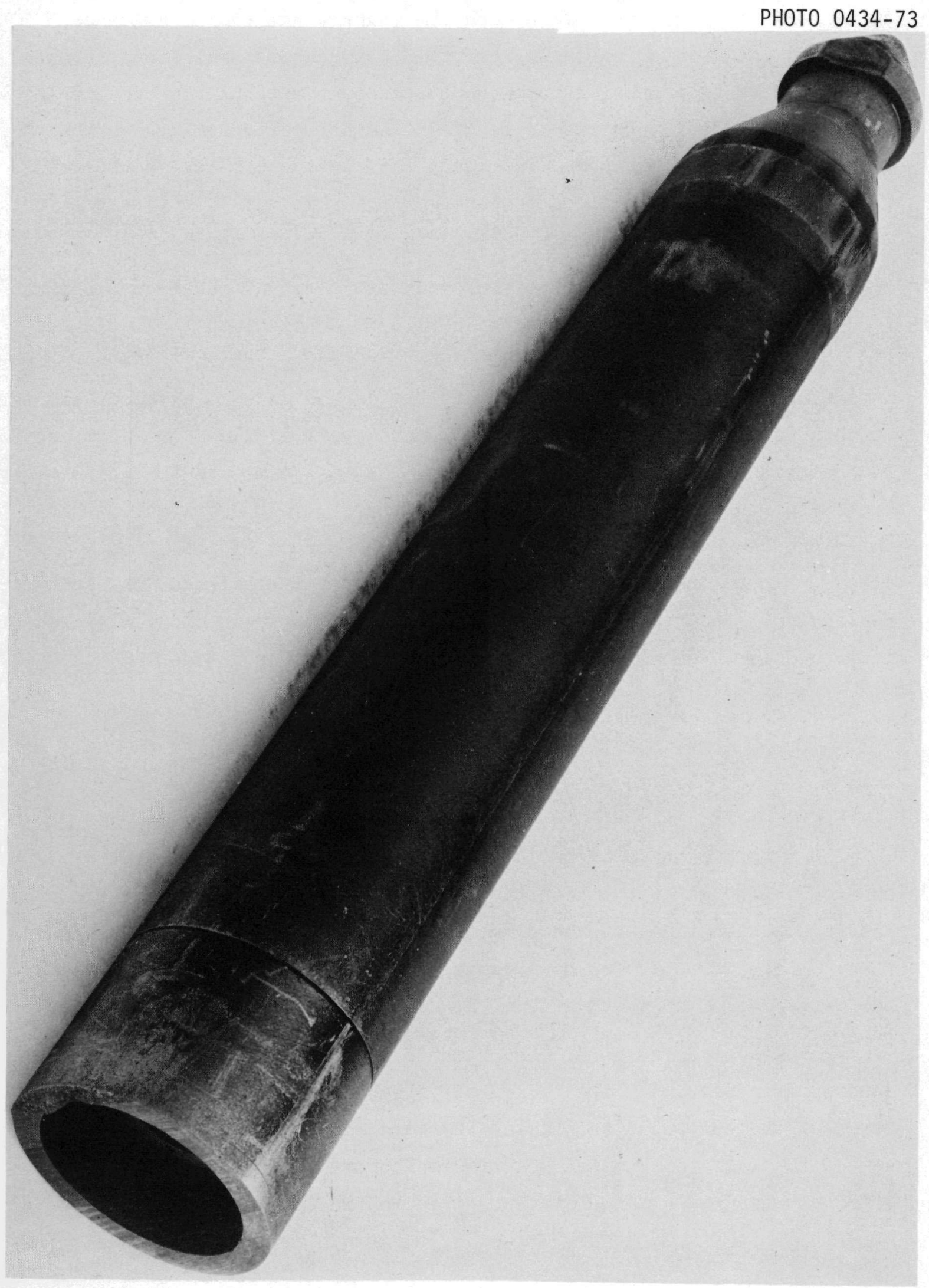

Fig. 4.1. External upper reflector region of element E06-01. 


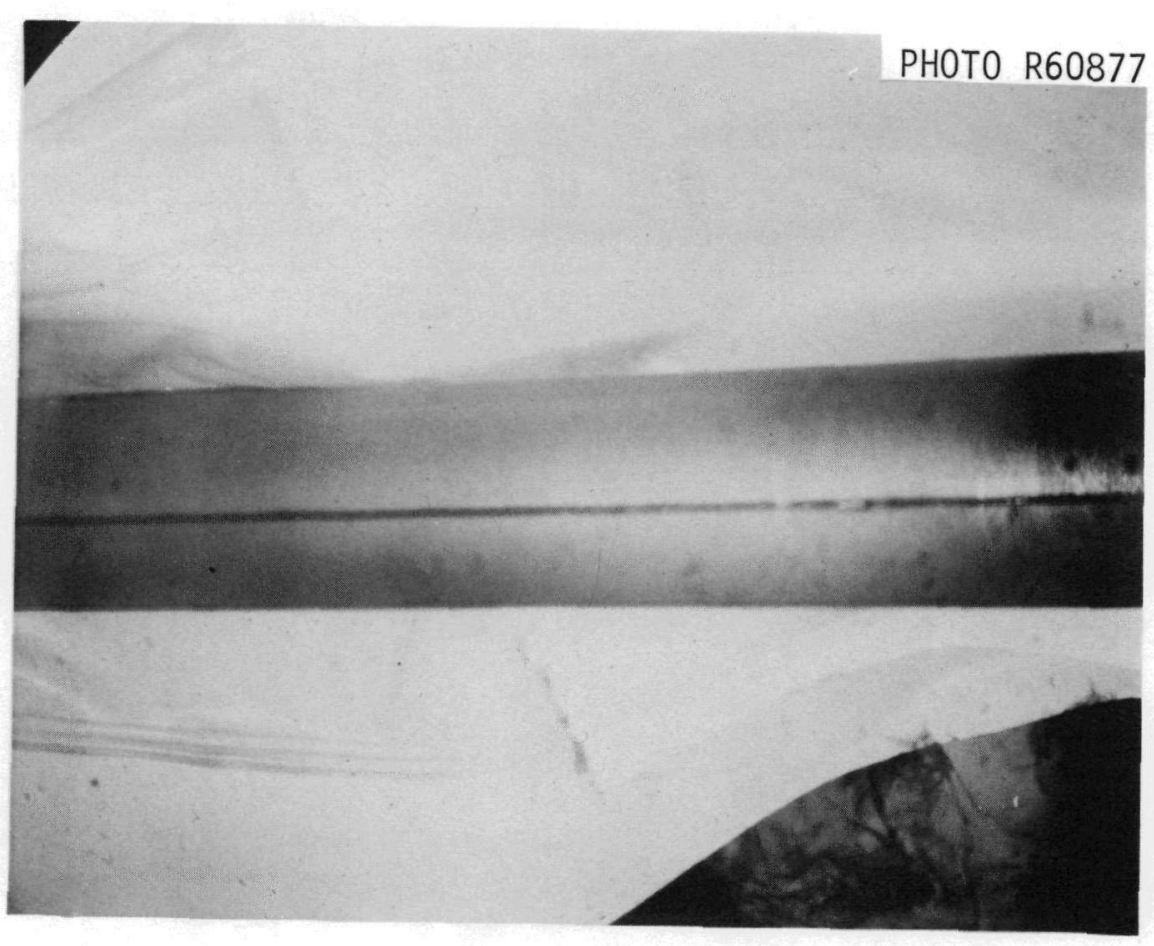

Fig. 4.2. Middle sleeve section of E06-01.

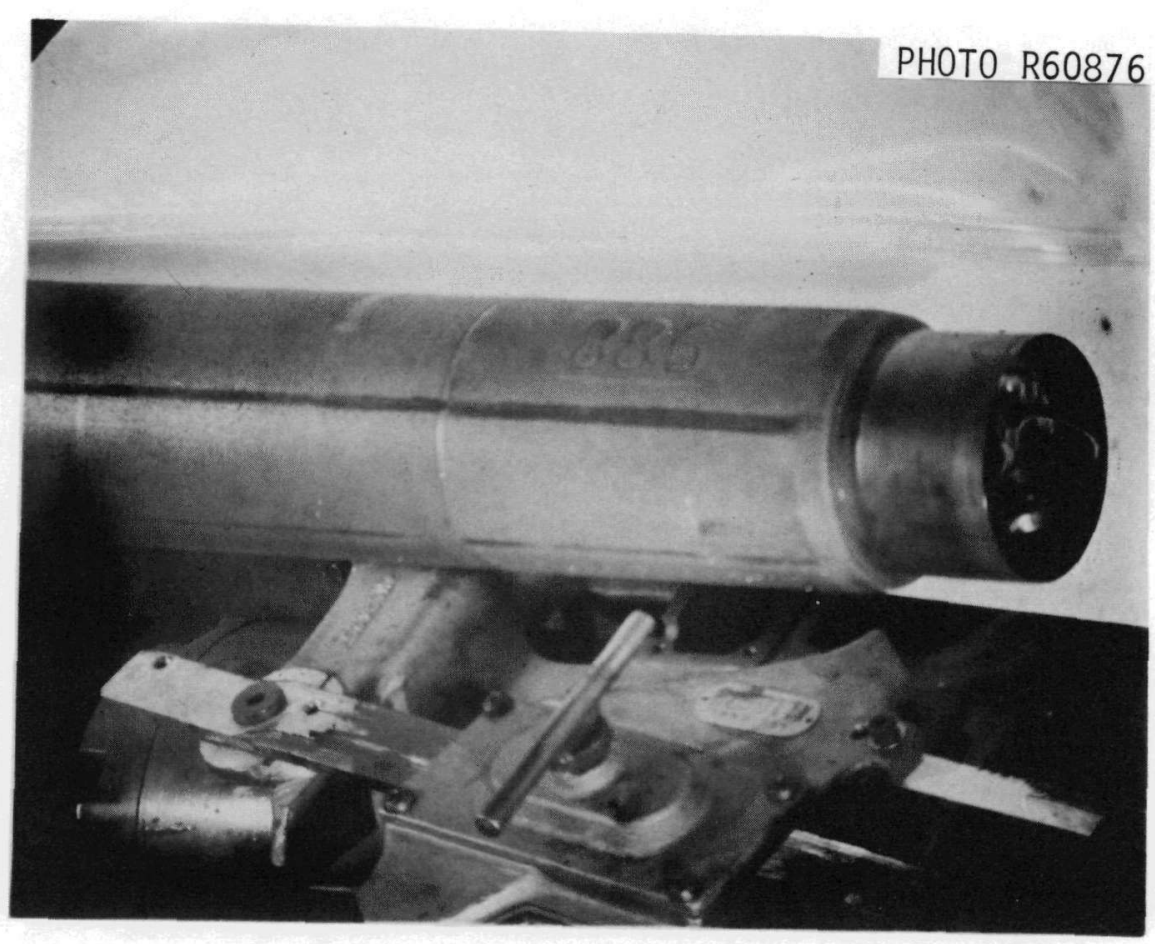

Fig. 4.3. Bottom section of EO6-OI. 
Table 4.1. Wall thicknesses of E06-01 fuel compacts

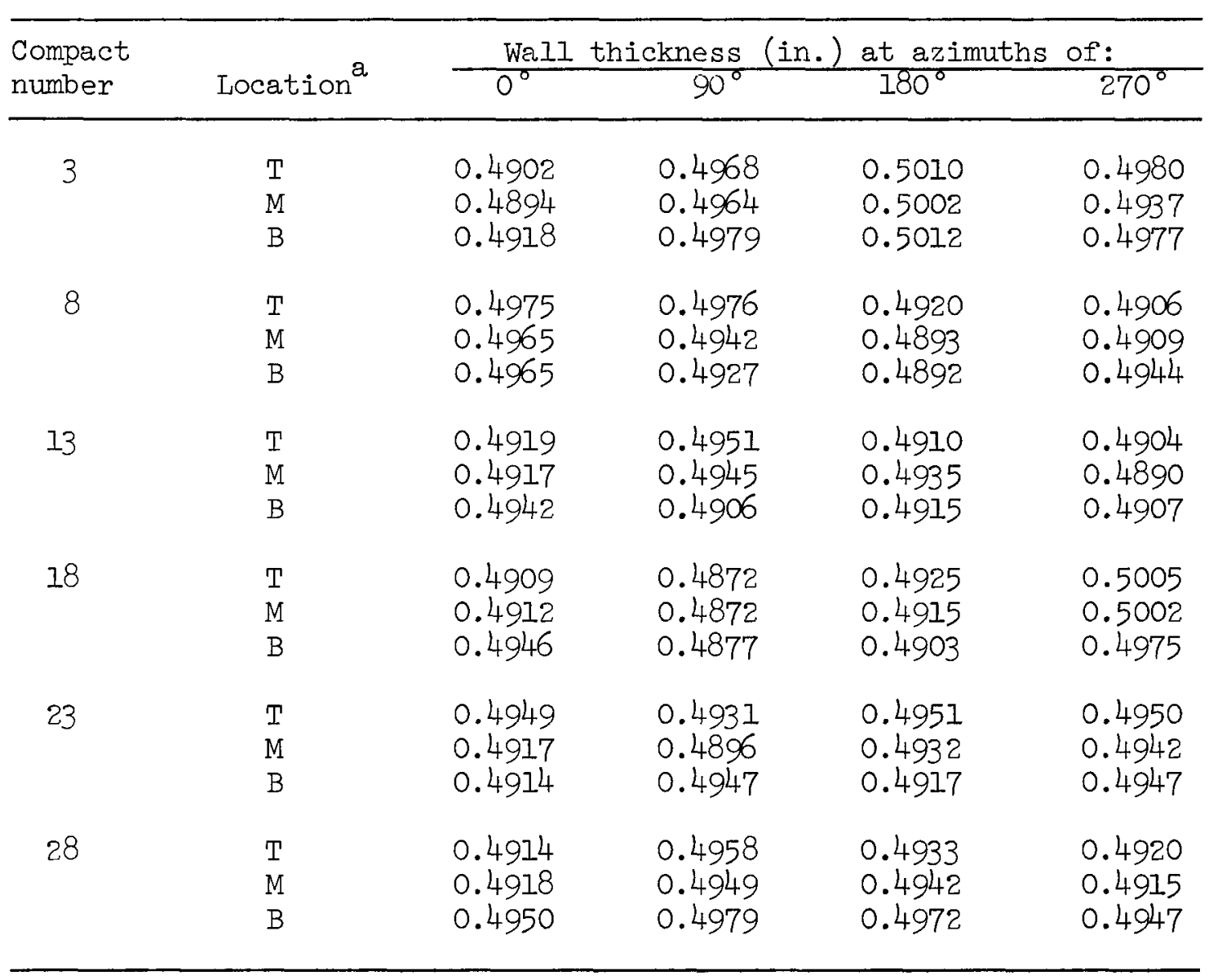

$\mathrm{a}_{\mathrm{T}}, \mathrm{M}$, and $\mathrm{B}$ denote the top, middle, and bottom, respectively, of the compact. 
Table 4.2. Outer and inner diameters of E06-01 fuel compacts

\begin{tabular}{|c|c|c|c|c|c|}
\hline \multirow[b]{3}{*}{$\begin{array}{l}\text { Compact } \\
\text { number }\end{array}$} & \multirow[b]{3}{*}{ Location $^{a}$} & \multicolumn{4}{|c|}{ Azimuth } \\
\hline & & \multicolumn{2}{|c|}{$0^{\circ}$} & \multicolumn{2}{|c|}{$90^{\circ}$} \\
\hline & & $\begin{array}{l}\mathrm{OD} \\
\text { (in.) }\end{array}$ & $\begin{array}{l}\text { ID } \\
\text { (in.) }\end{array}$ & $\begin{array}{l}O D \\
\text { (in.) }\end{array}$ & $\begin{array}{l}\text { ID } \\
\text { (in.) }\end{array}$ \\
\hline \multirow[t]{3}{*}{3} & $\mathrm{~T}$ & 2.7548 & 1.7636 & 2.7480 & 1.7532 \\
\hline & $\mathrm{M}$ & 2.7537 & 1.7641 & 2.7470 & 1.7569 \\
\hline & $B$ & 2.7557 & 1.7627 & 2.7487 & 1.7531 \\
\hline \multirow[t]{3}{*}{8} & $\mathrm{~T}$ & 2.7374 & 1.7479 & 2.7370 & 1.7488 \\
\hline & $M$ & 2.7362 & 1.7504 & 2.7340 & 1.7489 \\
\hline & B & 2.7374 & 1.7517 & 2.7332 & 1.7461 \\
\hline \multirow[t]{3}{*}{13} & $T$ & 2.7497 & 1,7668 & 2.7285 & 1.7430 \\
\hline & M & 2.7255 & 1.7403 & 2.7245 & 1.7410 \\
\hline & $B$ & 2.7272 & 1.7415 & 2.7255 & 1.7442 \\
\hline \multirow[t]{3}{*}{18} & $\mathrm{~T}$ & 2.7122 & 1.7288 & 2.7290 & 1.7413 \\
\hline & $\bar{M}$ & 2.7142 & 1.7315 & 2.7252 & 1.7378 \\
\hline & $B$ & 2.7162 & 1.7313 & 2.7264 & 1.7412 \\
\hline \multirow[t]{3}{*}{23} & $\mathrm{~T}$ & 2.7317 & 1.7417 & 2.7245 & 1.7364 \\
\hline & M & 2.7272 & 1.7423 & 2.7236 & 1.7398 \\
\hline & $B$ & 2.7302 & 1.7471 & 2.7262 & 1.7368 \\
\hline \multirow[t]{3}{*}{28} & $\mathrm{~T}$ & 2.7302 & 1.7455 & 2.7227 & 1.7349 \\
\hline & M & 2.7270 & 1.7410 & 2.7231 & 1.7367 \\
\hline & $B$ & 2.7498 & 1.7576 & 2.7307 & 1.7381 \\
\hline
\end{tabular}

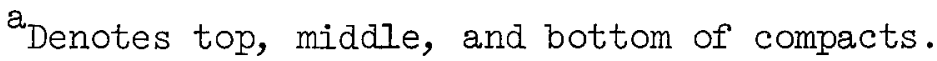

Table 4.3. Lengths of E06-01 fuel compacts

\begin{tabular}{cccccc}
\hline \multirow{2}{*}{$\begin{array}{l}\text { Compact } \\
\text { number }\end{array}$} & \multicolumn{4}{c}{ Length (in.) at azimuths of: } & \\
\cline { 2 - 5 } & $0^{\circ}$ & $90^{\circ}$ & $180^{\circ}$ & $270^{\circ}$ & Mean \\
\hline 3 & 3.0182 & 3.0228 & 3.0184 & 3.0174 & 3.0192 \\
8 & 3.0215 & 3.0222 & 3.0241 & 3.0255 & 3.0233 \\
13 & 2.9955 & 2.9921 & 2.9916 & 2.9912 & 2.9926 \\
18 & 3.0537 & 3.0517 & 3.0540 & 3.0550 & 3.0536 \\
23 & 2.9998 & 3.0043 & 2.9990 & 2.9903 & 2.9983 \\
28 & 2.9425 & 2.9341 & 2.9289 & 2.9409 & 2.9366 \\
& & & & Grand mean & 3.0039 \\
\hline
\end{tabular}


Because the gamma spectroscopic results were derived in terms of nuclide concentrations, it was necessary to determine the weights of several compacts before the fission product inventories in the fuel compacts could be calculated. For the same reason, it was necessary to determine the weights per unit length of the spines and sleeve. The results of these measurements are given in Table 4.4 .

Table 4.4. Weights of compacts and weights per unit length of sleeve and spines

\begin{tabular}{ccc}
\hline & & Weight $(\mathrm{g})$ \\
\hline \multirow{2}{*}{ Compact } & 7 & 342.3 \\
& 17 & 343.6 \\
& 20 & 337.6 \\
& & Mean \\
& 342.5
\end{tabular}

Weight per unit length (g/in.)

Sleeve 113.4 Spine 64

The soot that deposited on the top reflector (see Fig. 4.1) was analyzed for gamma and beta emitters. The data are reported in Table 4.5 .

4.2 Axial Distributions and Inventories of Radionuclides 4.2.1 Axial distributions of radionuclides in the purge inlet tube and porous plug

The axial distributions of radionuclides in the purge inlet tube and porous plug are given in Tables 4.6 and 4.7. The tabular data are expressed as microcuries per centimeter in both cases. The total inventories given in the tables were computed by summing the products of concentration and length of each measured section. 
Table 4.5. Concentrations of radionuclides in soot removed from the top reflector of element E06-01

\begin{tabular}{cc}
\hline Radionuclide & Concentration $(\mu \mathrm{Ci} / \mathrm{g} \mathrm{soot})^{2}$ \\
\hline $54_{\mathrm{Mn}}$ & 29.4 \\
$60 \mathrm{Co}$ & 53.1 \\
${ }^{95} \mathrm{Zr}$ & 2300. \\
$125 \mathrm{Sb}$ & 4.8 \\
$134 \mathrm{Cs}$ & 29.1 \\
$137 \mathrm{Cs}$ & 87.8 \\
$144 \mathrm{Ce}$ & 1000. \\
$182_{\mathrm{Ta}}$ & 50. \\
$89_{\mathrm{Sr}}$ & 2700. \\
90 & 25.4 \\
\hline
\end{tabular}

QValues corrected to January 6, 1972.

The distributions of the nuclides ${ }^{110 \mathrm{~m}} \mathrm{Ag},{ }^{134} \mathrm{Cs},{ }^{137} \mathrm{Cs}$, and ${ }^{144} \mathrm{Ce}$

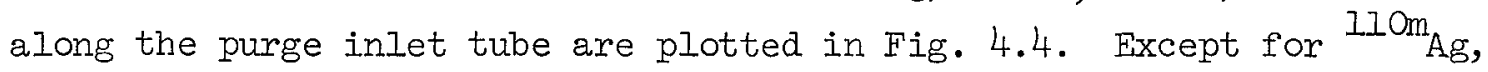
all distributions follow a similar pattern; that is, the activity decreases sharply from the top to near the central region of the purge inlet tube and then rapidly increases toward the exit end. Generally, the rate of increase toward the exit end was not quite as steep as the rate of decrease in the entrance end. Nearly all of the nuclides exhibit an even higher rate of increase in surface concentrations in the last 1 to $2 \mathrm{~cm}$ at the exit end. The distribution of ${ }^{110 \mathrm{~m}} \mathrm{Ag}$ does not have a minimum over the central region; instead, it increases over the entire length of the tube.

The mechanisms that govern the deposition of radionuclides in the tube are complex. The distributions depend on many factors, including the relative amounts of the radionuclides that exist as gases and dust-borne species, flow velocity, and the effects of boundary conditions near the ends of the tube. The Reynolds number for the helium flowing through the tube was about 600; thus the flow was laminar. The flow characteristics in the purge hole have not been analyzed to show the degree of efficiency 
Table 4.6. Axial distributions of radionuclides in the purge inlet tube in the top reflector

\begin{tabular}{|c|c|c|c|c|c|c|c|c|c|c|}
\hline \multirow{2}{*}{$\begin{array}{l}\text { Location } \\
\quad(\mathrm{cm})\end{array}$} & \multirow{2}{*}{$\begin{array}{l}\text { Section } \\
\text { length } \\
(\mathrm{cm})\end{array}$} & \multirow{2}{*}{$\operatorname{Mass}^{\mathrm{d}}$} & \multicolumn{8}{|c|}{ Nuclide content corrected to January $6,1972(\mu \mathrm{Ci} / \mathrm{cm} \times 100)$} \\
\hline & & & $54 \mathrm{Mn}$ & ${ }^{59} \mathrm{Fe}$ & ${ }^{60} \mathrm{Co}$ & ${ }^{110} \mathrm{Ag}$ & ${ }^{106} \mathrm{Ru}$ & $134 \mathrm{Cs}$ & $137_{\mathrm{Cs}}$ & ${ }^{144} \mathrm{Ce}$ \\
\hline 1.4 & 2.8 & 3.5 & 3.15 & 52.9 & 6.05 & 0.13 & 0.52 & 0.27 & 0.91 & 6.05 \\
\hline 5.2 & 4.8 & 6.2 & 0.97 & 21.9 & 2.85 & 0.14 & 0.17 & 0.11 & 0.33 & 1.09 \\
\hline 9.5 & 3.8 & $4 \cdot 9$ & 0.74 & 25.6 & 1.96 & 0.22 & 0.17 & 0.06 & 0.17 & 0.31 \\
\hline $13 \cdot 5$ & 4.2 & 5.5 & 0.67 & 13.1 & 0.92 & 0.34 & 0.12 & 0.06 & 0.16 & 0.45 \\
\hline 17.6 & 4.2 & 5.1 & 0.52 & 16.0 & 0.98 & 0.55 & 0.17 & 0.05 & 0.13 & 0.20 \\
\hline 21.8 & 4.1 & 5.2 & 0.49 & 12.8 & 0.00 & 0.81 & 0.17 & 0.08 & 0.17 & 0.13 \\
\hline 25.8 & 4.0 & 5.1 & 0.39 & 17.7 & 0.99 & 1.09 & 0.18 & 0.09 & 0.21 & 0.13 \\
\hline 29.8 & 4.0 & 5.2 & 0.43 & 25.9 & 1.23 & 1.52 & 0.31 & 0.12 & 0.24 & 0.14 \\
\hline 33.8 & 4.1 & 5.2 & 0.35 & 28.1 & 1.89 & 2.05 & 0.28 & 0.19 & 0.39 & 0.09 \\
\hline $37 \cdot 9$ & 4.2 & 5.2 & 0.38 & 42.8 & 2.04 & 2.52 & 0.33 & 0.20 & 0.35 & 0.11 \\
\hline 41.0 & 2.0 & 2.6 & 0.46 & 38.9 & 3.12 & 3.09 & 0.53 & 0.27 & 0.42 & 0.34 \\
\hline 42.9 & 1.8 & 2.3 & 2.85 & 82.1 & 8.02 & 4.19 & 0.85 & 0.41 & 0.79 & 1.20 \\
\hline \multicolumn{3}{|c|}{ Total inventory ${ }^{e}, \mu \mathrm{Ci} \times 100$} & 35.4 & 1210 & 91.3 & 51.7 & 11.8 & 6.0 & $13 \cdot 7$ & 30.9 \\
\hline
\end{tabular}

Data were obtained by cutting the top reflector into sections and drilling out the inner surface of the tube.

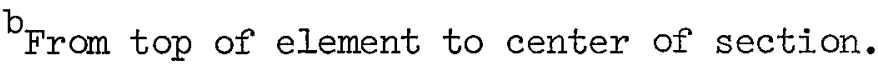

C Length of section.

Weight of graphite removed from inner surface of tube.

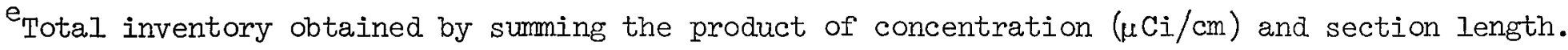


Table 4.7. Axial distributions of gamma emitters in the porous plug in element E06-01

\begin{tabular}{|c|c|c|c|c|c|c|c|}
\hline \multirow{2}{*}{$\begin{array}{l}\text { Distance } \\
\quad(\mathrm{cm})\end{array}$} & \multirow{2}{*}{$\begin{array}{l}\text { Section } \\
\text { length } \\
\quad(\mathrm{cm})\end{array}$} & \multicolumn{6}{|c|}{ Nuclide content corrected to January $6,1972(\mu \mathrm{Ci} / \mathrm{cm})$} \\
\hline & & $\sqrt{46 \mathrm{Sc}}$ & ${ }^{60} \mathrm{Co}$ & $110 \mathrm{~m}_{\mathrm{Ag}}$ & ${ }^{134} \mathrm{Cs}$ & $137_{\mathrm{Cs}}$ & ${ }^{154} \mathrm{Eu}$ \\
\hline 1.70 & $3 \cdot 3$ & 123 & 39.8 & 17.6 & 1.64 & 0.94 & 6.52 \\
\hline 4.40 & 2.2 & 253 & 72.0 & 15.1 & 5.59 & 3.09 & 16.4 \\
\hline 6.50 & 2.0 & 314 & 74.4 & & 5.00 & 1.20 & 20.6 \\
\hline 8.40 & 1.8 & 372 & 76.9 & & 5.89 & 1.61 & 22.3 \\
\hline 10.20 & 1.8 & 407 & 71.7 & & 6.61 & 1.17 & 27.0 \\
\hline \multirow[t]{2}{*}{12.30} & 2.4 & 421 & 48.0 & & 6.50 & 0.75 & 26.2 \\
\hline & Inventory, $\mu \mathrm{Ci}$ & 4002 & 821.2 & & 65.80 & 19.1 & 250.4 \\
\hline
\end{tabular}

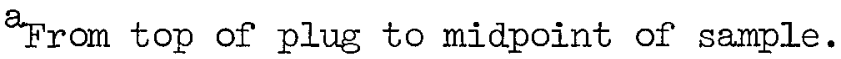




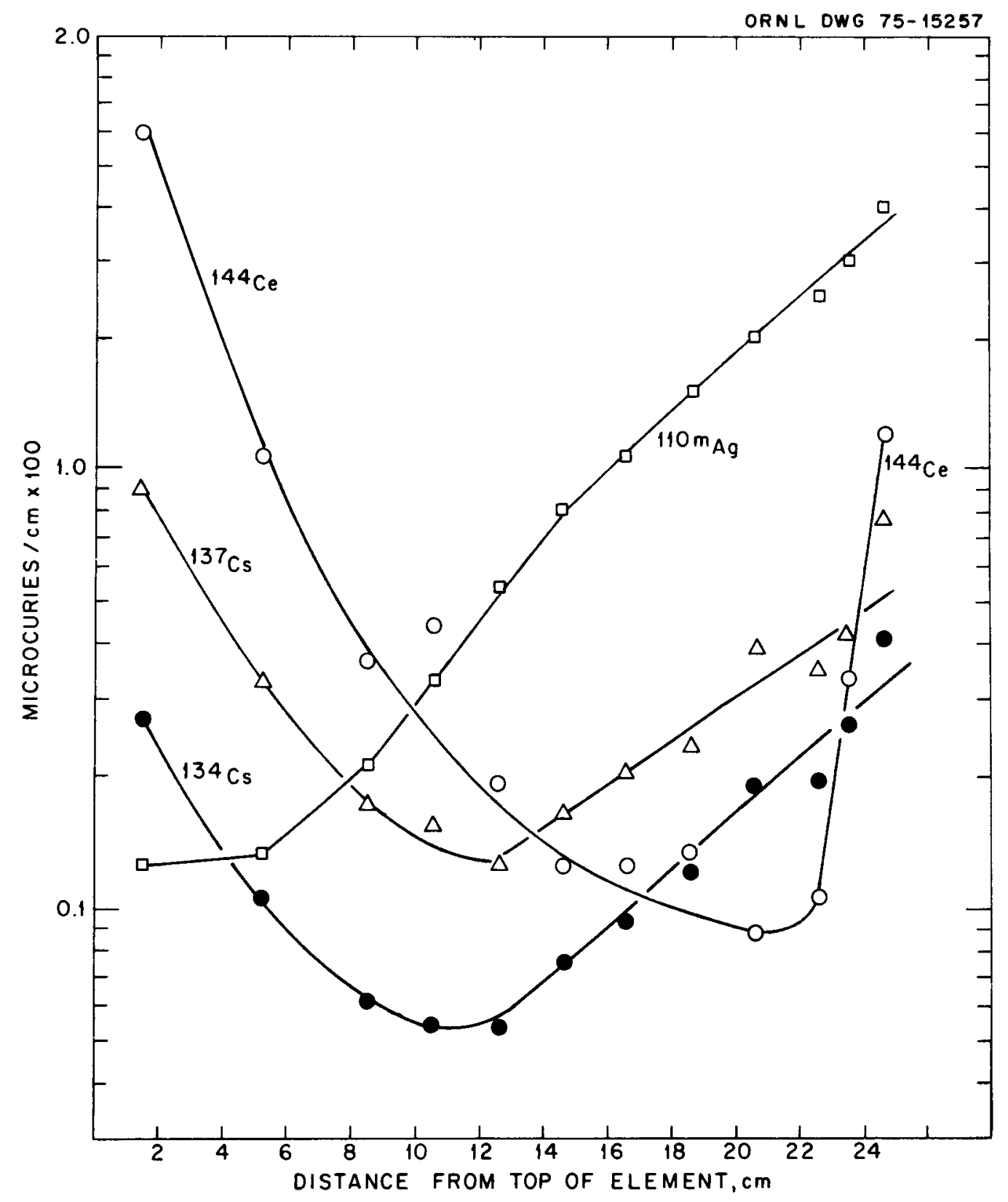

Fig. 4.4. Axial distributions of ${ }^{110 \mathrm{~m}} \mathrm{Ag},{ }^{134} \mathrm{Cs}, 137 \mathrm{Cs}$, and ${ }^{144} \mathrm{Ce}$ in purge inlet tube. 
at which the tube would collect gaseous or dust-borne species. The developing velocity profile near the inlet with relatively high mass transfer conditions may explain the decreasing surface concentration in the first several centimeters of the tube. At present, we have no explanation for the increase in surface concentrations in the latter half of the tube, particularly the steep increases shown for several of the radionuclides.

\subsubsection{Axial distributions in the fueled region}

Fuel compacts. The levels of ${ }^{95} \mathrm{Zr},{ }^{103} \mathrm{Ru},{ }^{106} \mathrm{Ru},{ }^{125} \mathrm{Sb},{ }^{134} \mathrm{Cs}$, $137 \mathrm{Cs},{ }^{144} \mathrm{Ce}$, and ${ }^{154} \mathrm{Eu}$ detected and measured in the fuel compacts are listed in Table 4.8 .

The results obtained from gamma scans of the fuel compacts, spine, and sleeve were normalized. to represent the amounts of radionuclides in 3-in. sections corresponding to the length of a fuel compact. These data were first derived as activities per gram and then normalized by using the weight units given in Table 4.4. Fractional releases of fission products per compact can thus be estimated from the data by dividing the sum of the spine and sleeve values by the totals given for the compacts, spine, and sleeve.

The amounts of radionuclides found in core-drilled specimens from three fuel compacts (compacts 8, 18, and 27) and in eight cross-sectional pieces cut from the spine pieces and sleeve (at compact positions 2, 3, 4, 7, 10, 14, 16, 22, and 26) are given in Tables 4.9, 4.10, and 4.11 respectively. Although these specimens were primarily used to derive counting efficiencies for the gamma scan measurements and to measure ${ }^{3} \mathrm{H}$ and $90 \mathrm{Sr}$ axial distributions in the spine and sleeve, the amounts of garma emitters measured were converted to curies per 3 in. of component so that these data might be compared directly with the gamma scan results.

Europium-155, which emits a 105-keV gamma ray, was also detected in the fuel. However, counting of the fuel particles on a Ge(Ii) $x$-ray detector showed that the $105-\mathrm{keV}$ photopeak is partly formed by uranium $\mathrm{x}$-rays which are presumably excited by beta particles and other radiations within 
Table 4.8. Inventory of gamma emitters in EO6-OI fuel compacts

(Data reported as curies per compact, corrected to January 6, 1972)

\begin{tabular}{|c|c|c|c|c|c|c|c|c|}
\hline \multirow{2}{*}{$\begin{array}{l}\text { Compact } \\
\text { number }\end{array}$} & \multicolumn{8}{|c|}{ Radionuclide } \\
\hline & $\overline{95} \mathrm{zr}$ & ${ }^{103} \mathrm{Ru}$ & ${ }^{106} \mathrm{Ru}$ & $125_{\mathrm{Sb}}$ & $134 \mathrm{Cs}$ & $137_{\mathrm{Cs}}$ & ${ }^{144} \mathrm{Ce}$ & ${ }^{154} \mathrm{Eu}$ \\
\hline 1 & 130 & & 5.89 & 0.22 & 1.61 & 4.49 & 72.5 & 0.03 \\
\hline 2 & 128 & 59 & 5.43 & 0.20 & 1.75 & 4.27 & 74.5 & 0.04 \\
\hline 3 & 126 & & 5.14 & 0.32 & 2.04 & 4.15 & 73.1 & 0.04 \\
\hline 4 & 153 & & 6.07 & 0.27 & 2.75 & 5.11 & 85.7 & 0.05 \\
\hline 5 & 173 & 80 & 6.71 & 0.27 & 3.47 & 5.77 & 95.4 & 0.07 \\
\hline 6 & 198 & 88 & 7.96 & 0.27 & 4.36 & 6.50 & 107.5 & 0.08 \\
\hline 7 & 197 & & 7.66 & 0.27 & 4.48 & 6.38 & 97.1 & 0.09 \\
\hline 8 & 201 & & 8.16 & 0.33 & 4.76 & 6.61 & 115.0 & 0.10 \\
\hline 9 & 248 & & 10.25 & 0.42 & 6.06 & 8.00 & 139.8 & 0.17 \\
\hline 10 & 224 & & 9.82 & 0.41 & 5.62 & $7 \cdot 35$ & 126.3 & 0.11 \\
\hline 11 & 228 & & 9.31 & 0.38 & 5.88 & 7.43 & 126.5 & 0.14 \\
\hline 12 & 122 & & 4.87 & 0.38 & 3.26 & 4.01 & 65.2 & 0.07 \\
\hline 13 & 253 & & 9.48 & 0.38 & 6.54 & 8.10 & 143.0 & 0.13 \\
\hline 15 & 243 & & 9.84 & 0.41 & 6.33 & 7.84 & 136.8 & 0.14 \\
\hline 15 & 218 & & 8.96 & 0.37 & 5.70 & 7.11 & 119.7 & 0.15 \\
\hline 16 & 228 & 95 & 8.80 & 0.39 & 5.85 & 7.22 & 128.7 & 0.15 \\
\hline 17 & 2.15 & & 8.34 & 0.34 & 5.61 & 6.95 & 119.4 & 0.14 \\
\hline 18 & 223 & 88 & 9.15 & 0.34 & 5.78 & 7.18 & 126.8 & 0.14 \\
\hline 19 & 214 & 106 & 9.00 & 0.38 & 5.58 & 7.04 & 114.3 & 0.11 \\
\hline 20 & 230 & 110 & 9.19 & 0.34 & 5.82 & 7.42 & 127.3 & 0.12 \\
\hline 21 & 207 & 86 & 8.52 & 0.35 & $5 \cdot 36$ & 6.92 & 118.1 & 0.12 \\
\hline 22 & 203 & & 8.52 & 0.30 & 5.09 & 6.77 & 114.9 & 0.09 \\
\hline 23 & 207 & 101 & 8.58 & 0.31 & 5.10 & 7.07 & 117.8 & 0.12 \\
\hline 24 & 185 & & 7.54 & 0.31 & 4.36 & 6.34 & 105.1 & 0.10 \\
\hline 25 & 175 & & 6.75 & 0.27 & $3 \cdot 92$ & 5.86 & 101.4 & 0.09 \\
\hline 26 & 167 & & 7.04 & 0.25 & 3.39 & 5.55 & 90.8 & 0.07 \\
\hline 27 & 158 & & 6.65 & 0.24 & 3.03 & 5.39 & 92.9 & 0.09 \\
\hline 28 & 140 & 71 & 6.11 & 0.24 & 2.39 & 4.77 & 82.6 & 0.09 \\
\hline 29 & 113 & & 4.51 & 0.22 & 1.70 & 3.83 & 62.0 & 0.04 \\
\hline 30 & 132 & & 5.60 & 0.21 & 1.63 & 4.53 & 79.2 & 0.04 \\
\hline Inventory, & & & & & & & & \\
\hline $\mathrm{Ci}$ & 5640 & & 230. & 9.4 & 129. & 186. & 3160. & 2.9 \\
\hline
\end{tabular}


Table 4.9. Radionuclides in core-drilled specimen of E06-01 fuel compacts (Data reported as curies per compact corrected to January 6, 1972)

\begin{tabular}{|c|c|c|c|c|c|c|c|c|c|}
\hline \multirow{2}{*}{$\begin{array}{l}\text { Compact } \\
\text { number }\end{array}$} & \multirow{2}{*}{$\begin{array}{l}\text { Specimen } \\
\text { number }\end{array}$} & \multicolumn{8}{|c|}{ Radionuclide } \\
\hline & & $\overline{95} \mathrm{Zr}$ & ${ }^{106} \mathrm{Ru}$ & ${ }^{125} \mathrm{Sb}$ & ${ }^{134} \mathrm{Cs}$ & $137 \mathrm{Cs}$ & ${ }^{144} \mathrm{Ce}$ & $154 \mathrm{Eu}$ & ${ }^{155_{\mathrm{Eu}}}$ \\
\hline 8 & 1 & 182 & 6.78 & 0.26 & 4.52 & 6.20 & 92 & 0.10 & 1.55 \\
\hline 8 & 2 & 181 & 8.39 & 0.35 & 4.80 & 6.61 & 109 & 0.10 & 1.52 \\
\hline 8 & 3 & 175 & 8.39 & 0.34 & 4.93 & 6.61 & 102 & 0.09 & 1.57 \\
\hline 18 & 1 & 194 & 9.49 & 0.41 & 5.96 & $7 \cdot 36$ & 116 & 0.11 & 1.68 \\
\hline 18 & 2 & 171 & 8.32 & 0.35 & 5.27 & 6.54 & 109 & 0.11 & 1.50 \\
\hline 18 & 3 & 202 & 9.28 & 0.39 & 5.82 & 7.23 & 123 & 0.14 & 1.59 \\
\hline 27 & 1 & 116 & 5.65 & 0.21 & 2.48 & 4.49 & 68 & 0.05 & 1.17 \\
\hline 27 & 2 & 130 & 6.51 & 0.24 & 2.88 & 5.14 & 81 & 0.05 & 1.09 \\
\hline 27 & 3 & 116 & 5.51 & 0.24 & 2.64 & 4.69 & 75 & 0.05 & 1.19 \\
\hline
\end{tabular}


Table 4.10. Inventories of radionuclides in sections cut from E06-01 spine ${ }^{a}$

[Data reported as (curies per 3 in. of spine) $x 10^{3}$, corrected to January 6, 1972]

\begin{tabular}{|c|c|c|c|c|c|c|c|c|c|c|c|c|}
\hline \multirow{2}{*}{$\begin{array}{l}\text { Compact } \\
\text { numberb }\end{array}$} & \multirow{2}{*}{$\begin{array}{l}\text { Specimen } \\
\text { mass } \\
(\mathrm{g})\end{array}$} & \multicolumn{11}{|c|}{ Radionuclide } \\
\hline & & ${ }^{46} \mathrm{Sc}$ & ${ }^{60} \mathrm{Co}$ & $9^{95}$ & ${ }^{106} \mathrm{Ru}$ & $110 \mathrm{~m}_{\mathrm{Ag}}$ & $134 \mathrm{Cs}$ & $137 \mathrm{Cs}$ & ${ }^{144} \mathrm{Ce}$ & ${ }^{154_{\mathrm{Eu}}}$ & $3_{H}$ & ${ }^{90} \mathrm{Sr}$ \\
\hline 2 & 3.75 & & 0.017 & & & 0.584 & 0.130 & 0.184 & 0.000 & & 0.105 & 0.040 \\
\hline 4 & 2.95 & & 0.022 & & & 0.812 & 0.170 & 0.234 & 0.470 & & 0.117 & 0.024 \\
\hline 7 & 4.31 & & 0.031 & & & 2.246 & 0.348 & 0.434 & 0.918 & & 0.294 & 0.041 \\
\hline 10 & 4.30 & & 0.077 & & & 0.396 & 0.411 & 0.465 & 1.334 & & 0.324 & 0.204 \\
\hline 14 & 4.15 & & 0.078 & & 0.23 & 0.390 & 0.332 & 0.378 & 1.956 & 0.003 & 0.342 & 0.288 \\
\hline 16 & 3.25 & & 0.178 & $3 \cdot 3$ & & 0.263 & 0.359 & 0.403 & 0.745 & 0.052 & 0.301 & 3.145 \\
\hline 22 & 2.66 & 2.48 & 0.242 & 25.7 & 0.11 & 0.000 & 0.553 & 0.470 & 1.096 & 0.321 & 0.213 & 4.415 \\
\hline 26 & 5.17 & 1.85 & 0.136 & 23.6 & 0.26 & 0.061 & 0.305 & 0.315 & 2.803 & 0.240 & 0.213 & 0.591 \\
\hline
\end{tabular}

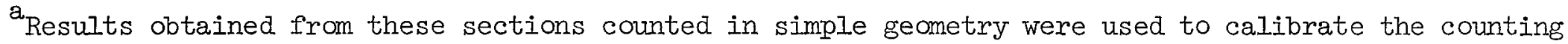
efficiency of the gamma scan.

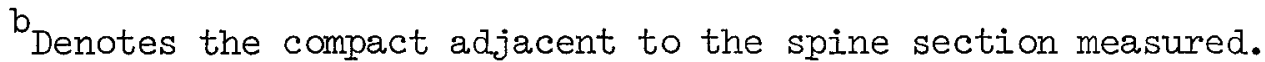


Table 4.11. Inventories of radionuclides in sections cut from E06-01 sleeve [Data reported as (curies per $3 \mathrm{in.}$ of sleeve) $\times 10^{3}$, corrected to January 6, 1972]

\begin{tabular}{|c|c|c|c|c|c|c|c|c|c|c|c|c|}
\hline \multirow{2}{*}{$\begin{array}{l}\text { Compact } \\
\text { numberb }\end{array}$} & \multicolumn{2}{|c|}{ Specimen } & \multicolumn{10}{|c|}{ Radionuclide } \\
\hline & $\begin{array}{l}\text { Length } \\
(\mathrm{cm})\end{array}$ & $\begin{array}{r}\text { Mass } \\
(\mathrm{g})\end{array}$ & $\sqrt{46} \mathrm{Sc}$ & ${ }^{54} \mathrm{Mn}$ & $60_{\mathrm{Co}}$ & ${ }^{106} \mathrm{Ru}$ & $110 m_{A g}$ & ${ }^{134} \mathrm{Cs}$ & $137_{\mathrm{Cs}}$ & $155_{\mathrm{Eu}}$ & $3_{\mathrm{H}}$ & $90 \mathrm{Sr}$ \\
\hline 2 & 0.440 & 9.800 & 1.290 & 0.018 & 0.209 & 0.010 & 0.000 & 0.110 & 0.240 & 0.109 & 2.020 & 0.065 \\
\hline 3 & 0.420 & 10.000 & 1.990 & 0.034 & 0.306 & 0.030 & 0.000 & 0.196 & 0.312 & 0.166 & 2.360 & 0.047 \\
\hline 7 & 0.440 & 8.300 & 2.980 & 0.029 & 0.412 & 0.060 & 0.000 & 0.384 & 0.493 & 0.217 & $3 \cdot 380$ & 0.067 \\
\hline 10 & 0.510 & 17.460 & 3.010 & 0.000 & 0.514 & 0.127 & 5.680 & 1.095 & 1.340 & 0.182 & 5.410 & 0.325 \\
\hline 14 & 0.350 & 8.050 & 3.050 & 0.047 & 0.493 & 0.864 & 4.050 & 0.956 & 1.157 & 0.211 & 8.400 & 0.222 \\
\hline 18 & 0.460 & 11.400 & 2.590 & 0.000 & 0.469 & 0.109 & 4.410 & 1.112 & 1.330 & 0.241 & 3.840 & 1.040 \\
\hline 22 & 0.430 & 9.550 & 2.320 & 0.000 & 0.466 & 0.041 & 2.600 & 0.687 & 0.891 & 0.114 & 2.030 & 2.040 \\
\hline 26 & 0.540 & 19.400 & 0.250 & 0.000 & 0.265 & 0.186 & 1.300 & 0.425 & 0.691 & 0.144 & 1.920 & 0.326 \\
\hline
\end{tabular}

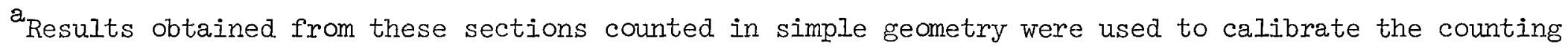
efficiency of the gamma scan.

$\mathrm{b}_{\text {Numbers }}$ denote compact number adjacent to section measured. 
the fuel particle kernel. Therefore, it was not possible to measure the ${ }^{155} \mathrm{Eu}$ nondestmuctively with a Ge(Li) gamma-ray detector.

The axial distributions of ${ }^{106} \mathrm{Ru},{ }^{134} \mathrm{Cs},{ }^{13} 7_{\mathrm{Cs}},{ }^{125} \mathrm{Sb}$, and ${ }^{154} \mathrm{Eu}$ in the fuel as measured by gamma scanning are shown in Figs. 4.5 and 4.6, where the concentrations (given in Table 4.8) relative to the concentration of ${ }^{95} \mathrm{Zr}$ in each compact are plotted vs compact number.

Zirconium-95 is used here as a migration monitor since it is known to be one of the least mobile of the gamma-emitting fission products. Therefore, the horizontal aspect of the concentration ratios of ${ }^{106} \mathrm{Ru}$, ${ }^{134} \mathrm{Cs},{ }^{137} \mathrm{Cs},{ }^{125} \mathrm{Sb},{ }^{144} \mathrm{Ce}$, and ${ }^{154} \mathrm{Eu}$ relative to $95 \mathrm{Zr}$ indicates that no gross movement of these nuclides took place in element E06-0I. $106 \frac{\text { Axial distributions in spine. }}{110 \mathrm{~m}} \mathrm{Ag},{ }^{134} \mathrm{Cs}, 137 \mathrm{Cs},{ }^{144} \mathrm{Ce}$, and ${ }^{154} \mathrm{Eu}$ were detected and their contents measured in the spine and sleeve; these data are presented in Tables 4.10-4.13. The beta emitters $3_{\mathrm{H}}$ and $90 \mathrm{Sr}$ were measured by radiochemical analysis only in the cross-sectional pieces cut from the spine and sleeve. The gamma emitters were measured by axially scanning the sleeve and spine and by gamma spectroscopy of cross-sectional pieces cut from each component. Ruthenium-106, a beta emitter, was determined by counting the gamma rays from its $30-$ sec half-life daughter, ${ }^{106} \mathrm{Rh}$. Zirconium-95 concentrations were determined after accounting for the interference from the ${ }^{154} \mathrm{Eu}$ photopeak (see sect. 3.10.3). In so doing, it was found that ${ }^{95} \mathrm{Zr}$ appeared to be present at only a few locations in the spine as indicated from both the gamma scan and measurements of the cut specimens.

The axial distributions of ${ }^{134} \mathrm{Cs}$ and ${ }^{137} \mathrm{Cs}$ in the spine are shown in Fig. 4.7, where the concentration values of Table 4.12, given in terms of millicuries per $3 \mathrm{in}$. of spine, are plotted vs the adjacent compact number. The concentration profiles roughly follow those found in the fuel. The data show considerable scatter from one compact position to the next in the central fuel element region (see Fig. 4.7). The pronounced peaks at compact locations 10 and 20 may be related to the interface between the three spine pieces that existed at these two locations. The added 


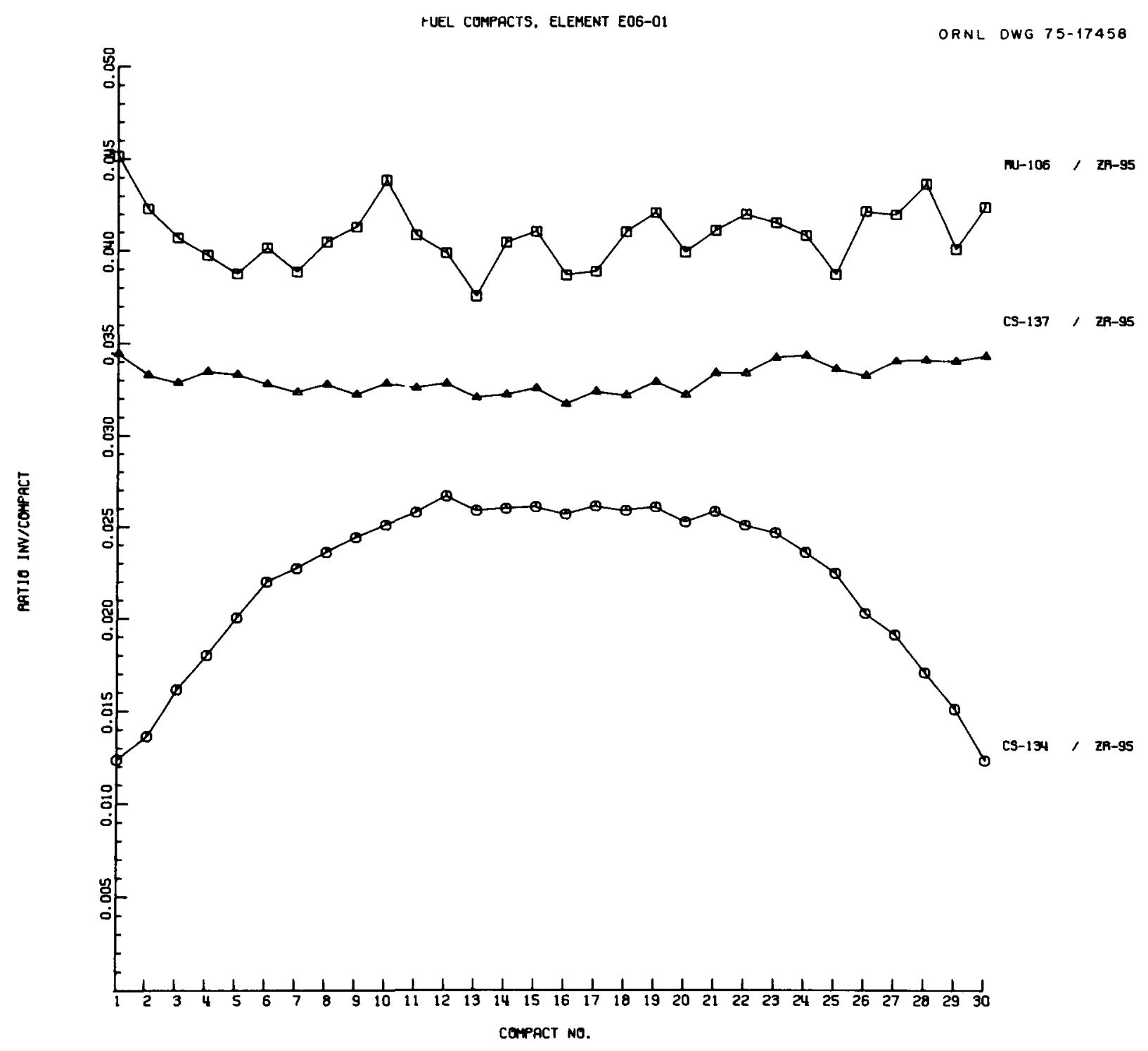

\footnotetext{
Fig. 4.5. Axial distributions of ${ }^{106} \mathrm{Ru},{ }^{134} \mathrm{Cs}$, and ${ }^{137} \mathrm{Cs}$ relative to $95 \mathrm{Zr}$ in fuel compacts.
} 
FuEL COMPACTS. ELEMENT E06-01

ORNL DWG 75-17462

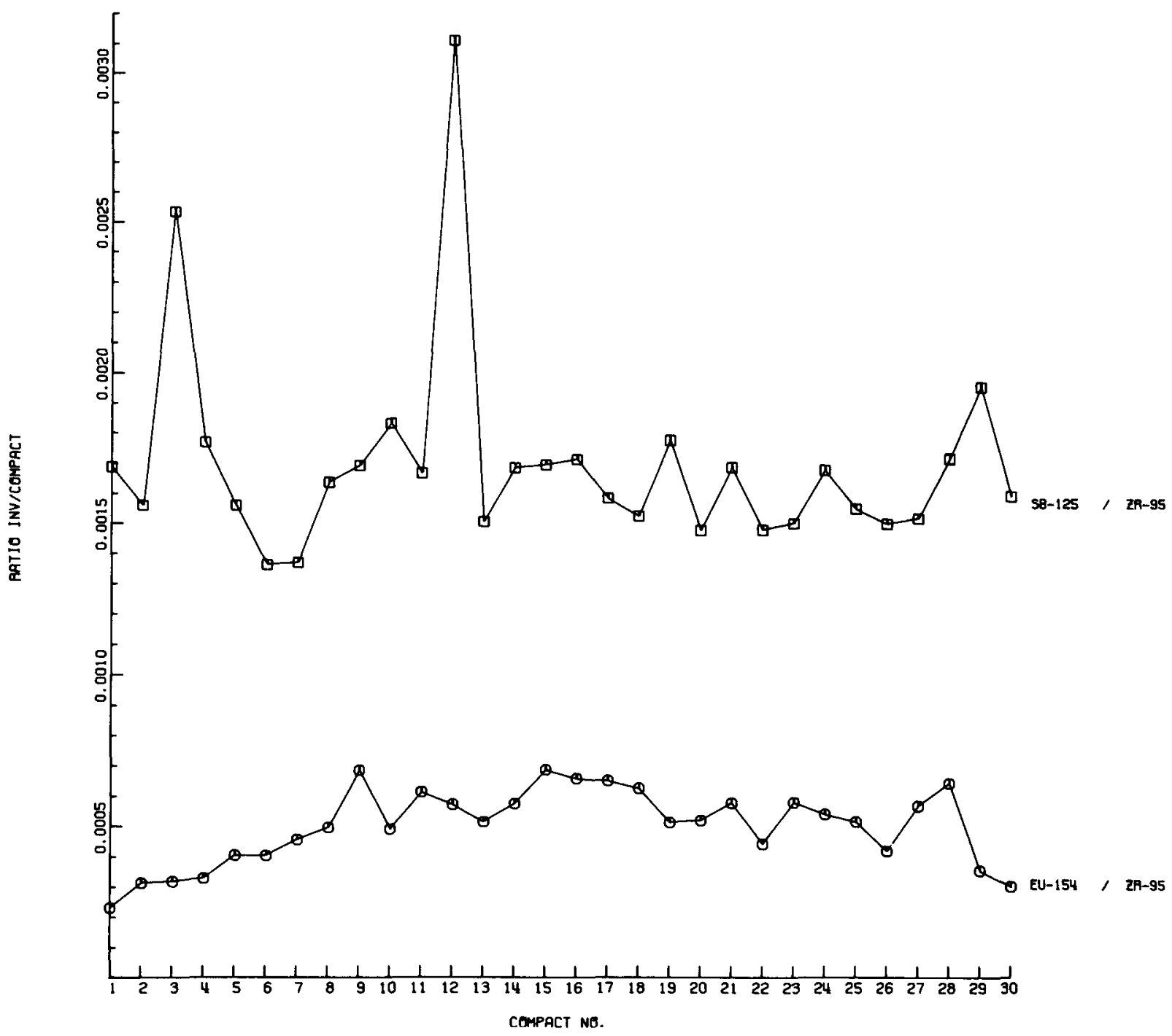

Fig. 4.6. Axial distributions of ${ }^{125} \mathrm{Sb}$ and ${ }^{154} \mathrm{Eu}$ relative to ${ }^{95} \mathrm{Zr}$ in fuel compacts. 
Table 4.12. Axial distributions of gamma emitters in E06-01 spine

[Data reported as (curies per 3 in. of spine) $\times 10^{3}$, corrected to January 6, 1972]

\begin{tabular}{|c|c|c|c|c|c|c|c|c|c|}
\hline \multirow{2}{*}{$\begin{array}{l}\text { Compact } \\
\text { number }\end{array}$} & \multicolumn{9}{|c|}{ Gamma emitter } \\
\hline & ${ }^{46} \mathrm{Sc}$ & ${ }^{60} \mathrm{Co}$ & $95 \mathrm{Zr}$ & ${ }^{106} \mathrm{Ru}$ & $110 \mathrm{~m}_{\mathrm{Ag}}$ & ${ }^{134} \mathrm{Cs}$ & $137_{\mathrm{Cs}}$ & ${ }^{144} \mathrm{Ce}$ & $\overline{154_{\mathrm{Eu}}}$ \\
\hline 1 & & 0.000 & & 0.142 & 0.07 & 0.094 & 0.204 & 1.34 & \\
\hline 2 & & 0.020 & & 0.000 & 0.61 & 0.138 & 0.211 & & \\
\hline 3 & & 0.023 & & 0.257 & 1.78 & 0.209 & 0.282 & & \\
\hline 4 & & 0.023 & & 0.403 & 2.65 & $0.24 \overline{4}$ & 0.326 & & \\
\hline 5 & & 0.032 & & 0.515 & 2.66 & 0.307 & 0.415 & & \\
\hline 6 & & 0.031 & & 0.420 & 2.11 & 0.326 & 0.413 & & \\
\hline 7 & & 0.033 & & 0.326 & 1.63 & 0.342 & 0.430 & & \\
\hline 8 & & 0.035 & & 0.315 & 0.67 & 0.357 & 0.436 & & \\
\hline 9 & & 0.040 & & 0.171 & 0.42 & 0.392 & 0.478 & & \\
\hline 10 & & 0.071 & & 0.749 & 0.57 & 0.739 & 0.943 & 9.17 & \\
\hline 11 & & 0.033 & & 0.211 & 0.87 & 0.524 & 0.628 & 2.01 & \\
\hline 12 & & 0.060 & & 0.171 & 0.57 & 0.649 & 0.753 & & \\
\hline 13 & & 0.080 & & 0.167 & 0.38 & 0.428 & 0.493 & 1.47 & \\
\hline 14 & & 0.099 & & 0.275 & 0.73 & 0.369 & 0.432 & & \\
\hline 15 & & 0.175 & & 0.188 & 0.75 & 0.386 & 0.447 & 1.79 & 1.46 \\
\hline 16 & & 0.112 & & 0.174 & 0.33 & 0.351 & 0.399 & & 0.02 \\
\hline 17 & & 0.131 & & 0.000 & 0.14 & 0.334 & 0.371 & & 0.03 \\
\hline 18 & & 0.238 & 3.0 & 0.149 & 0.09 & 0.403 & 0.505 & & 0.08 \\
\hline 19 & & 0.179 & & 0.194 & & 0.340 & 0.424 & 2.24 & 0.04 \\
\hline 20 & & 0.349 & 5.0 & 1.943 & & 0.862 & 1.125 & 24.36 & 0.10 \\
\hline 21 & & 0.645 & 3.5 & 0.171 & & 0.451 & 0.342 & & 0.31 \\
\hline 22 & & 0.346 & & 0.136 & & 0.480 & 0.386 & & 0.29 \\
\hline 23 & 1.8 & 0.280 & & 0.148 & & 0.438 & 0.376 & 1.55 & 0.29 \\
\hline 24 & & 0.010 & & 0.000 & & 0.023 & 0.022 & & 0.01 \\
\hline 25 & 1.9 & 0.140 & 3.0 & 0.230 & & 0.361 & 0.340 & 0.63 & 0.25 \\
\hline 26 & 1.9 & 0.131 & 5.0 & 0.269 & & 0.311 & 0.338 & 2.45 & 0.24 \\
\hline 27 & 1.5 & 0.106 & 6.0 & 0.319 & & 0.257 & 0.288 & 3.93 & 0.21 \\
\hline 28 & 1.5 & 0.132 & 4.0 & 0.269 & & 0.192 & 0.236 & 3.07 & 0.19 \\
\hline 29 & 1.2 & 0.079 & 2.0 & 0.173 & 0.03 & 0.140 & 0.113 & 1.28 & 0.17 \\
\hline 30 & 1.1 & 0.086 & & 0.088 & & 0.109 & 0.044 & & 0.16 \\
\hline Inventor & , $\mathrm{Ci} \times 10^{3}$ & 3.72 & & 8.57 & & 10.6 & 12.2 & & \\
\hline
\end{tabular}

\footnotetext{
Denotes the compact adjacent to spine section measured.
} 
Table 4.13. Axial distributions of gamma emitters in E06-01 sleeve

[Data reported as (curies per 3 in. of sleeve) $\times 10^{3}$, corrected to January 6, 1972]

\begin{tabular}{|c|c|c|c|c|c|c|c|c|c|}
\hline \multirow{2}{*}{$\begin{array}{l}\text { Compact } \\
\text { number }\end{array}$} & \multicolumn{9}{|c|}{ Gamma emitter } \\
\hline & $\sqrt[49 \mathrm{Sc}]{ }$ & ${ }^{60} \mathrm{Co}$ & $95_{\mathrm{Zr}}$ & ${ }^{106} \mathrm{Ru}$ & $110 \mathrm{~m}_{\mathrm{Ag}}$ & $134 \mathrm{Cs}$ & $137_{\mathrm{Cs}}$ & ${ }^{144} \mathrm{Ce}$ & $154 \mathrm{Eu}$ \\
\hline$I$ & 1.16 & 0.16 & 6.40 & 0.37 & 0.00 & 0.12 & 0.32 & 6.84 & 0.10 \\
\hline 2 & 0.99 & 0.19 & 6.40 & 0.40 & 0.00 & 0.15 & 0.34 & 5.88 & 0.10 \\
\hline 3 & 1.36 & 0.21 & 6.10 & 0.40 & 0.00 & 0.16 & 0.36 & 4.73 & 0.10 \\
\hline 4 & 1.53 & 0.24 & 8.50 & 0.50 & 0.00 & 0.24 & 0.48 & 8.88 & 0.13 \\
\hline 5 & 1.74 & 0.26 & 10.70 & 0.67 & 0.21 & 0.44 & 0.82 & 9.36 & 0.15 \\
\hline 6 & 1.77 & 0.28 & 7.00 & 0.55 & 0.00 & 0.44 & 0.76 & 6.80 & 0.14 \\
\hline 7 & 1.77 & 0.32 & 9.30 & 0.58 & 2.24 & 0.60 & 0.90 & 9.56 & 0.16 \\
\hline 8 & 2.00 & 0.36 & 7.90 & 0.00 & 0.65 & 0.81 & 1.11 & 9.90 & 0.14 \\
\hline 9 & 2.07 & 0.37 & 7.50 & 0.00 & 4.15 & 0.94 & 1.20 & 9.87 & 0.13 \\
\hline 10 & 2.11 & 0.41 & 9.80 & 0.00 & 5.24 & 1.08 & 1.37 & 10.41 & 0.15 \\
\hline 11 & 2.24 & 0.39 & 8.60 & 0.00 & 3.06 & 1.37 & 1.67 & 10.75 & 0.17 \\
\hline 12 & 2.18 & 0.41 & 9.00 & 0.70 & 2.45 & 1.26 & 1.54 & 12.76 & 0.16 \\
\hline 13 & 2.04 & 0.37 & 8.90 & 0.00 & 4.05 & 1.15 & 1.50 & 8.33 & 0.16 \\
\hline 14 & 2.14 & 0.40 & 10.60 & 0.86 & 3.47 & 1.09 & 1.42 & 11.50 & 0.15 \\
\hline 15 & 2.24 & 0.37 & 8.60 & 0.73 & 2.65 & 1.07 & 1.31 & 10.20 & 0.14 \\
\hline 16 & 2.00 & 0.37 & 9.20 & 0.00 & $3 \cdot 33$ & 1.10 & 1.37 & 8.30 & 0.17 \\
\hline 17 & 2.00 & 0.52 & 12.40 & 1.28 & 2.86 & 1.61 & 2.03 & 17.10 & 0.19 \\
\hline 18 & 1.97 & 0.42 & 10.20 & 1.24 & 2.96 & 1.10 & 1.33 & 10.20 & 0.19 \\
\hline 19 & 1.84 & 0.41 & 8.70 & 0.68 & 2.11 & 0.90 & 1.19 & 9.70 & 0.15 \\
\hline 20 & 2.62 & 0.53 & 7.30 & 0.00 & 2.42 & 1.33 & 1.84 & 10.20 & 0.18 \\
\hline 21 & 2.76 & 0.52 & 4.80 & 0.00 & 2.14 & 1.00 & 1.42 & 10.20 & 0.21 \\
\hline 22 & 7.52 & 0.48 & 9.40 & 0.00 & 2.31 & 1.05 & 1.49 & 11.90 & 0.20 \\
\hline 23 & 1.77 & 0.40 & 10.00 & 0.00 & 1.84 & 0.95 & 1.48 & 11.70 & 0.19 \\
\hline 24 & 1.63 & 0.31 & 11.00 & 0.00 & 1.97 & 0.87 & 1.43 & 10.20 & 0.11 \\
\hline 25 & 1.22 & 0.29 & 7.00 & 0.00 & 1.60 & 0.67 & 1.22 & 8.50 & 0.10 \\
\hline 26 & $3 \cdot 50$ & 0.33 & 8.00 & 0.00 & 1.22 & 0.54 & 1.00 & 6.80 & 0.14 \\
\hline 27 & 1.33 & 0.29 & 8.00 & 0.00 & 0.99 & 0.49 & 1.01 & 4.60 & 0.07 \\
\hline 28 & 1.43 & 0.27 & 7.00 & 0.00 & 0.71 & 0.41 & 0.93 & 3.40 & 0.07 \\
\hline 29 & 1.36 & 0.28 & 45.00 & 1.46 & 0.00 & 0.96 & 1.59 & 104.00 & 0.07 \\
\hline 30 & 1.36 & 0.18 & 0.00 & 0.00 & 0.00 & 0.18 & 0.36 & 0.00 & 0.07 \\
\hline Inventory, & & & & & & & & & \\
\hline $\mathrm{Ci} \times 10^{\circ}$ & 61.6 & 10.2 & 283. & 10.4 & 54.6 & 24.1 & 34.8 & 356. & 4.20 \\
\hline
\end{tabular}

Microcurie/gram results determined by gamma scanning were normalized to Ci per 3 in. of sleeve

based on a measured value of $113.4 \mathrm{~g}$ per inch of sleeve.

Numbers denote compact number adjacent to measured sleeve section. 
SPINE GRRPHITE, ELEMENT E06-01

ORNL OWG 75-17461

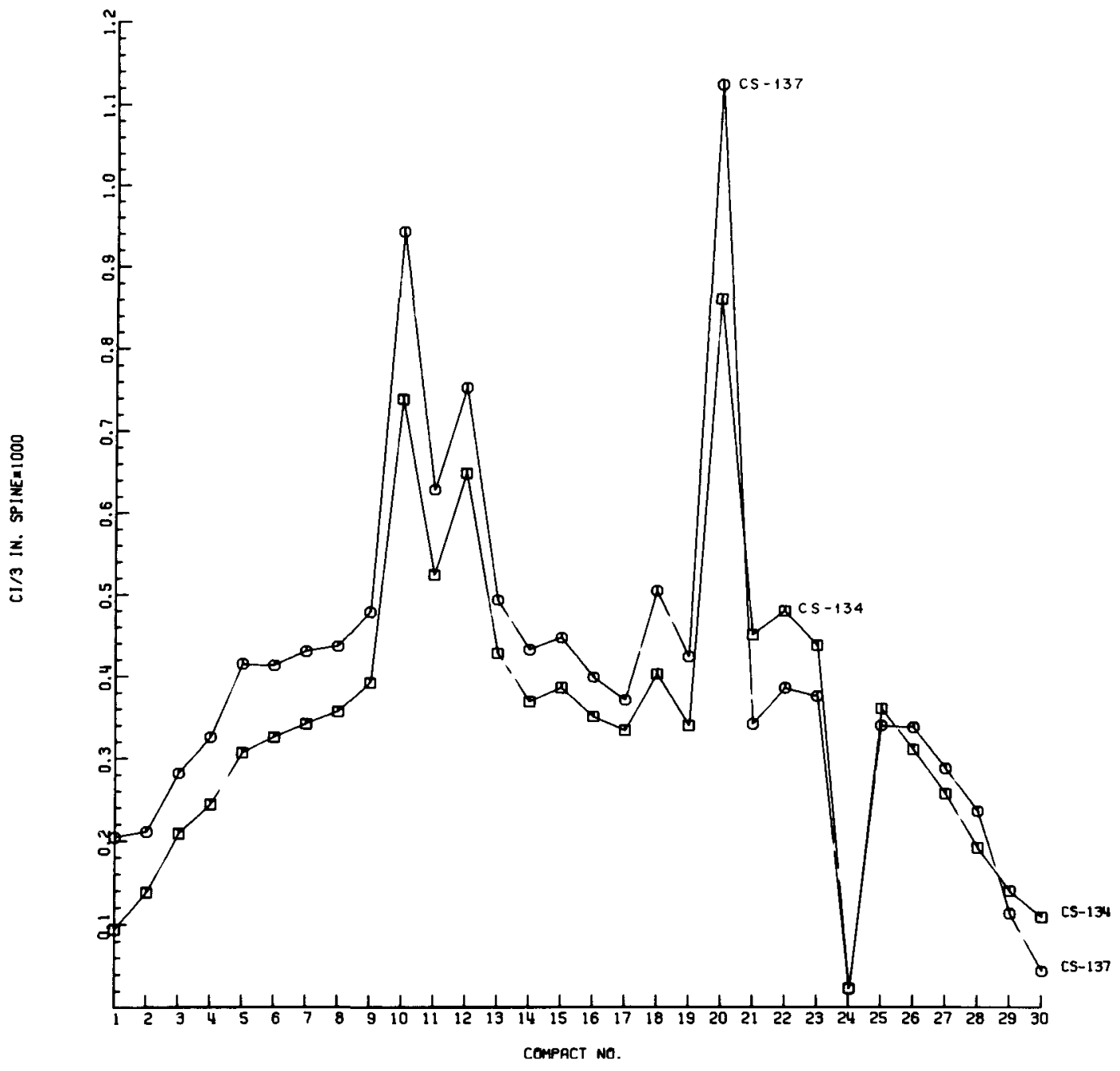

Fig. 4.7. Axial distributions of ${ }^{134} \mathrm{Cs}$ and ${ }^{137} \mathrm{Cs}$ in E06-0I spine. 
surface contributed by the ends of the spine piece evidently presented additional sites for cesium adsorption. However, concentration peaks at these two locations did not occur for any other radionuclide measured.

Axial distributions of ${ }^{106} \mathrm{Ru}$, shown in Fig. 4.8, exhibited a broad dip in concentration over the central region and pronounced maxima at locations 5, 20, and 27. Although $110 \mathrm{~m}_{\mathrm{Ag}}$ was not detected in the highertemperature region of the top spine, it was found in relatively large amounts in the bottom spine. This behavior indicates a high mobility of silver in the high-temperature regions relative to the low-temperature zones.

The distributions of ${ }^{3} \mathrm{H}$ and $90_{\mathrm{Sr}}$ in the spine are shown in Fig. 4.9. Since measurement of these nuclides was limited to the cross-sectional pieces, the distributions are known only in very rough outline. However, it appears that the ${ }^{3} \mathrm{H}$ concentrations approximately follow the neutron fluence experienced by the element, as shown in Fig. 2.9. The ${ }^{90} \mathrm{Sr}$ concentrations were relatively high in the highest-temperature regions but very low elsewhere.

The ${ }^{46} \mathrm{Sc},{ }^{60} \mathrm{Co}$, and ${ }^{154} \mathrm{Eu}$, which were present at very low levels, generally appeared in measurable amounts only in the top spine piece. Except for the possibility that some ${ }^{154} \mathrm{Eu}$ may have been present on the spine as fuel contamination, these radionuclides can be accounted for via neutron capture reactions by trace contamination of their stable precursors in the spine.

Axial distributions in sleeve. Figure 4.10 shows that the distributions of ${ }^{134} \mathrm{Cs}$ and ${ }^{137} \mathrm{Cs}$ in the sleeve are somewhat similar to those in the spine (see Fig. 4.7 for comparison).

The axial distribution of ${ }^{110 \mathrm{~m}} \mathrm{Ag}$ in the sleeve is shown in Fig. 4.11. Although the data show a great deal of scatter, the distribution appears to be similar to that found in the spine. As can be seen, the concentration rapidly increases down the element to the vicinity of compact position 10 and then very rapidly decreases throughout the remainder of the element. This break point in the distribution is closer to the top of the element than in the case of the spine. 


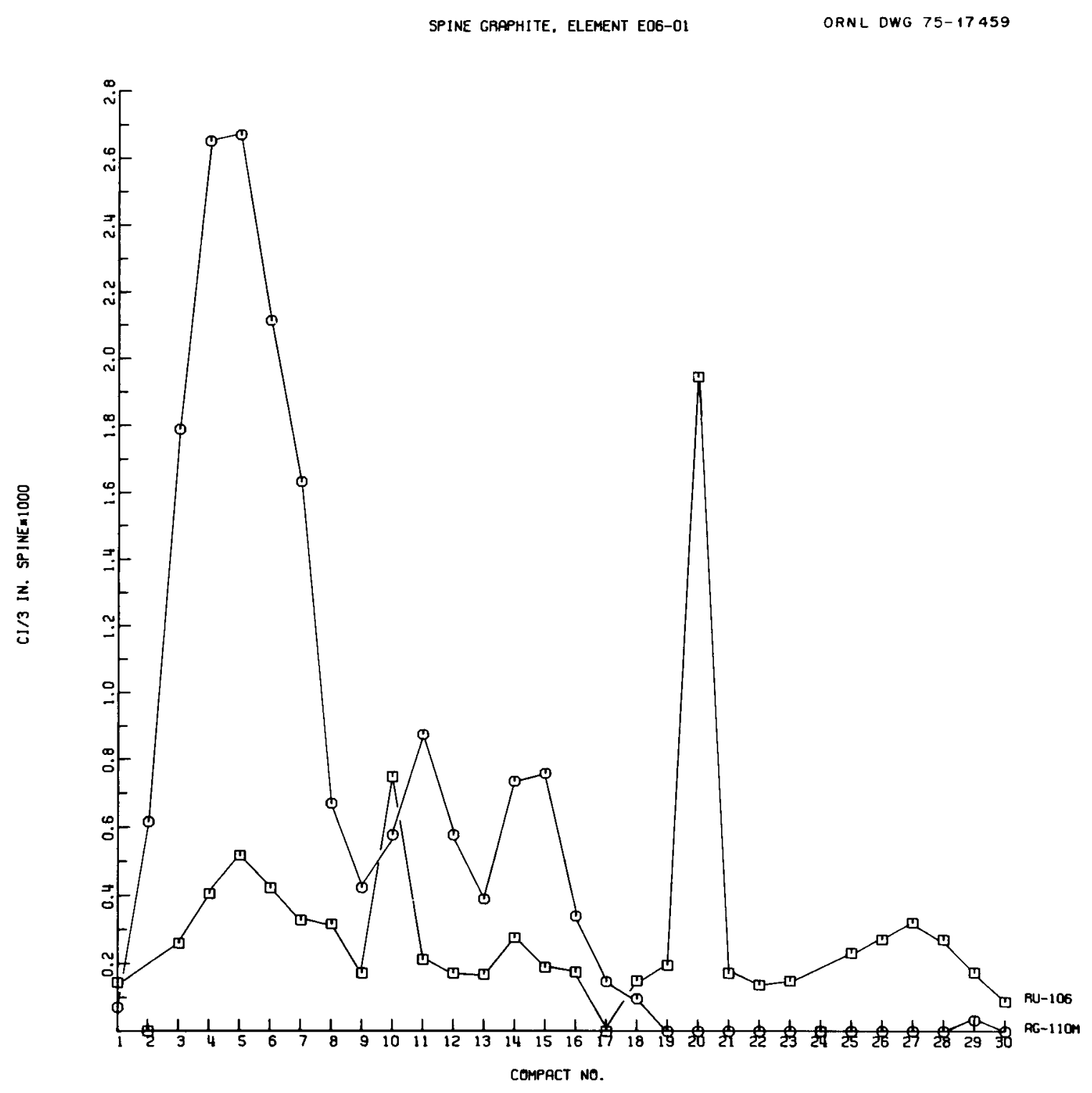

Fig. 4.8. Axial distributions of ${ }^{106} \mathrm{Ru}$ and ${ }^{110 \mathrm{~m}} \mathrm{Ag}$ in E06-01 spine. 


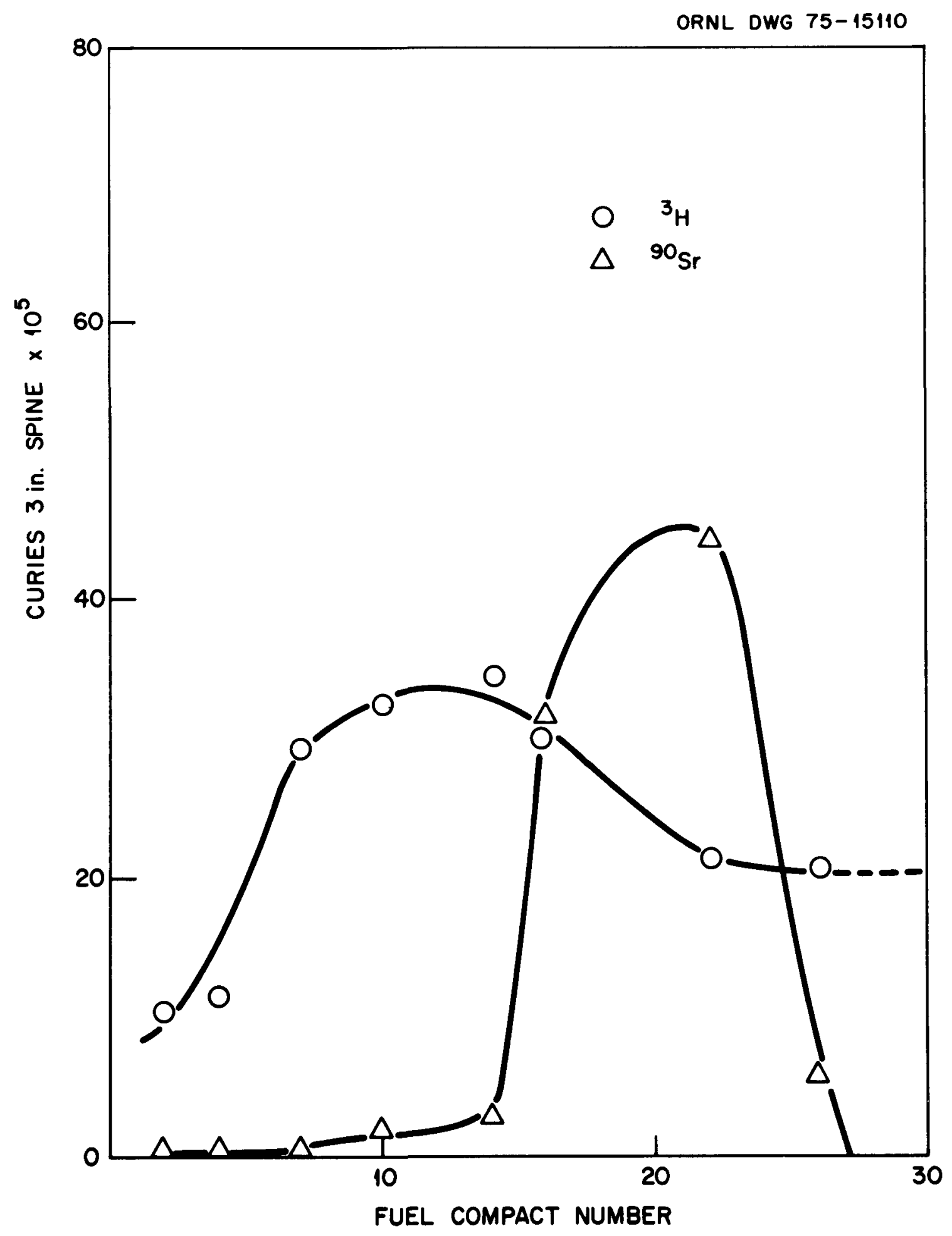

Fig. 4.9. Axial distributions of ${ }^{3} \mathrm{H}$ and ${ }^{90} \mathrm{Sr}$ in EO6-OI spine, corrected to January 6, 1972. 
SLEEve 'Graphite, element E06-01

ORNL OWG 75-17457

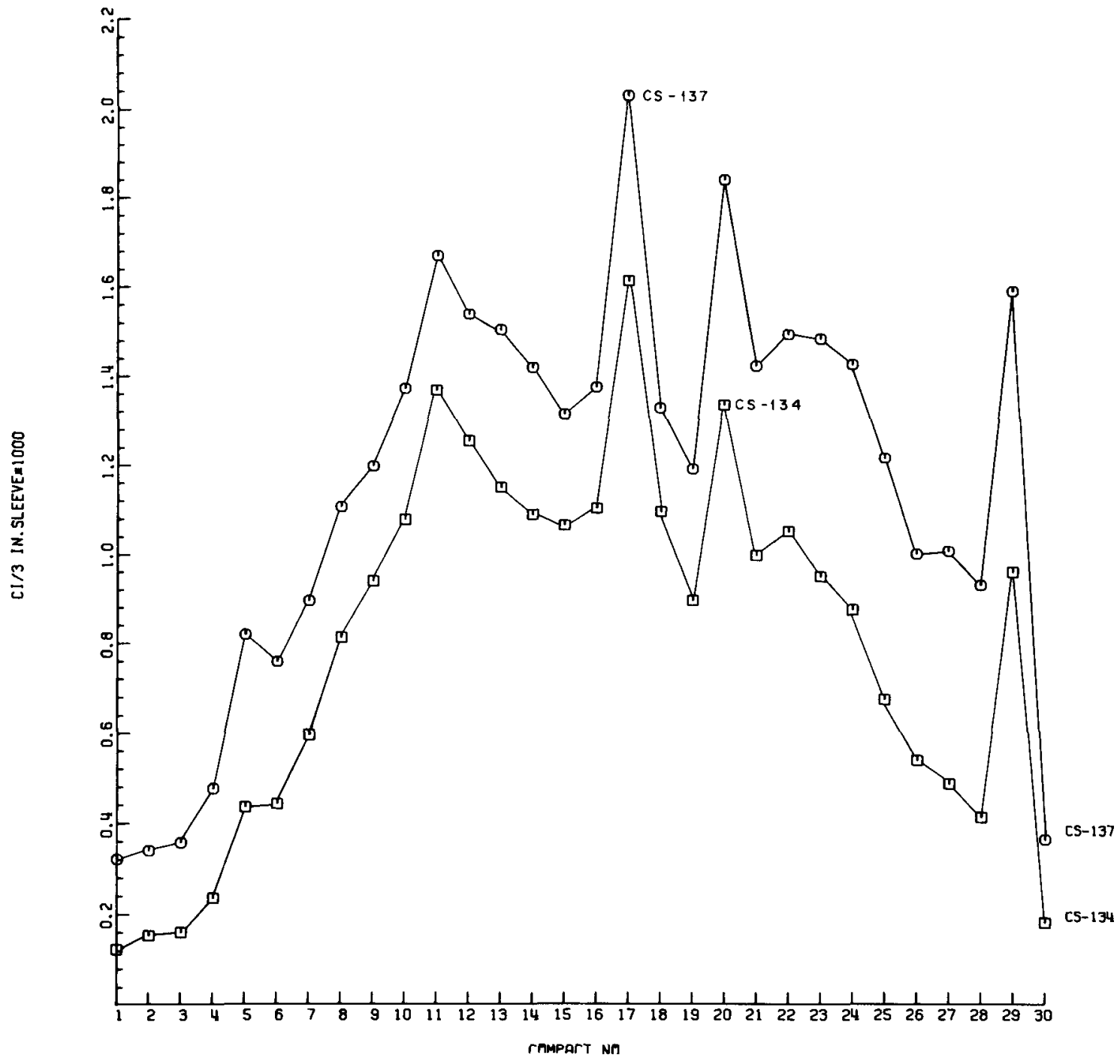

Fig. 4.10. Axial distributions of ${ }^{134} \mathrm{Cs}$ and ${ }^{137} \mathrm{Cs}$ in E06-01 sleeve. 


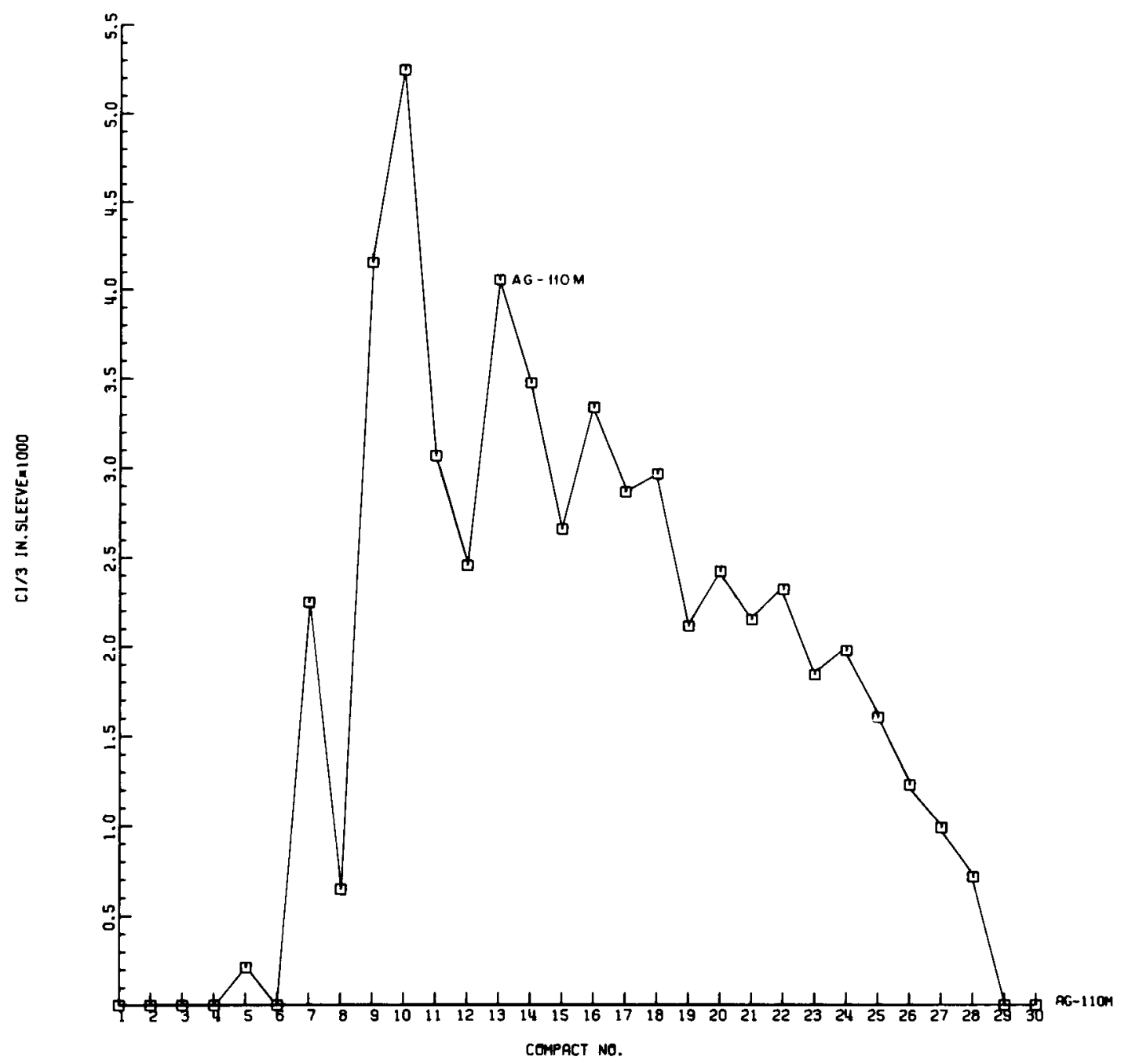

Fig. 4.11. Axial distributions of ${ }^{110 \mathrm{~m}} \mathrm{Ag}$ in E06-01 sleeve, corrected to January 6, 1972. 
Fission product trap. The radionuclides ${ }^{60} \mathrm{Co},{ }^{65} \mathrm{Zn},{ }^{106} \mathrm{Ru},{ }^{134} \mathrm{Cs}$, $137 \mathrm{Cs}$, and ${ }^{144} \mathrm{Ce}$ were found in the fission product trap. Concentrations as a function of axial location in the trap are given in Table 4.14. It is interesting to note that, a.Ithough ${ }^{1.10 \mathrm{~m}} \mathrm{Ag}$ is mobile in the fuel, none of this radionuclide was found in the trap. (The charcoal in the trap was not analyzed for beta emitters.) As shown in Fig. 4.12, the concentrations of ${ }^{134} \mathrm{Cs}$, ${ }^{137} \mathrm{Cs}$, and ${ }^{144} \mathrm{Ce}$ quickly reached a maximum in the first 3 in. of the trap and then abruptly decreased. The concentrations of ${ }^{137} \mathrm{Cs}$ and ${ }^{144} \mathrm{Ce}$ were low and nearly uniform throughout the last $5 \mathrm{in}$. of the trap. Both of these radionuclides may be deposited by transfer from the fuel as metallic species and by decay of their gaseous precursors in passing through the trap. Cesium-134 may occur in the trap as a result of four mechanisms: (1) transfer of metallic ${ }^{134} \mathrm{Cs}$ from the fuel, (2) neutron activation of $133 \mathrm{Cs}$ that is transferred as metallic cesium, (3) neutron activation of ${ }^{133} \mathrm{Cs}$ that is deposited in the trap by the decay of $133 \mathrm{Xe}$, and (4) neutron activation of ${ }^{133} \mathrm{Cs}$ that is initially present in the charcoal as an impurity. It seems likely, however, that the relatively large amount of ${ }^{134} \mathrm{Cs}$ present near the front of the trap is due to deposition of metallic ${ }^{134} \mathrm{Cs}$.

Table 4.14. Axial distributions of radionculides in E06-01. fission product trap

[Data reported as microcuries per inch of trap, corrected to January 6, 1972]

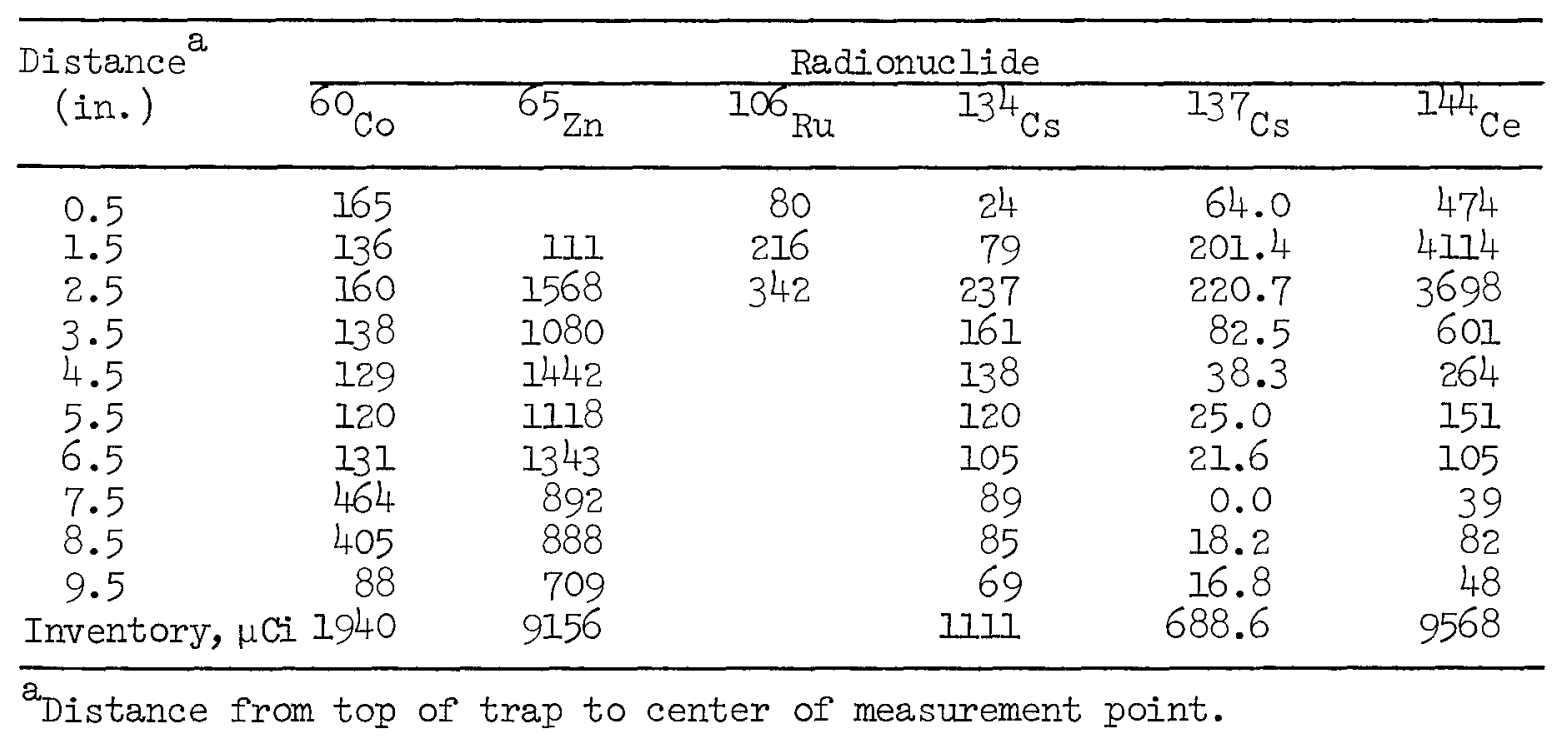




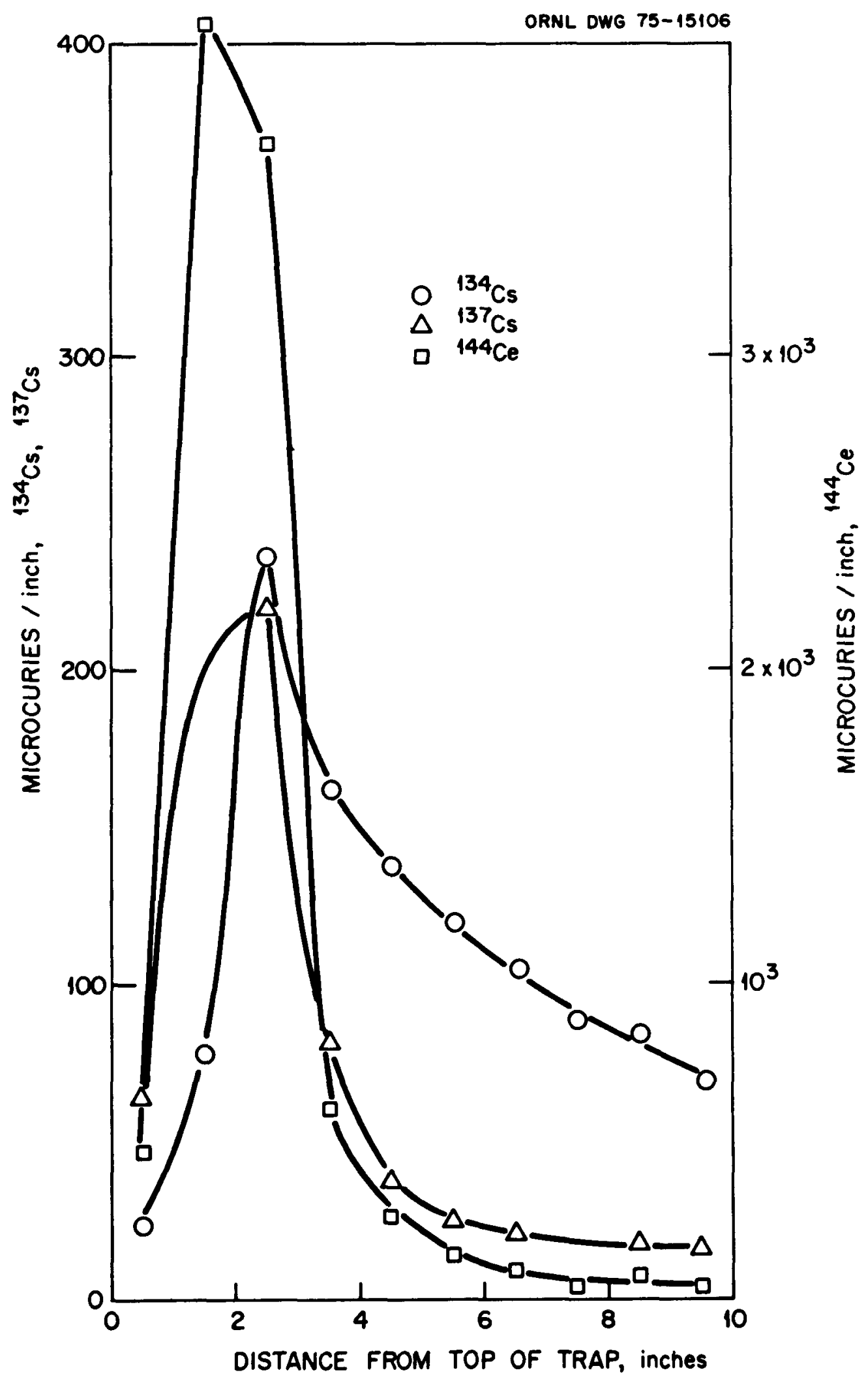

Fig. 4.12. Axial distributions of ${ }^{134} \mathrm{Cs},{ }^{137} \mathrm{Cs}$, and ${ }^{144} \mathrm{Ce}$ in fission product trap. 


\subsection{Radial Distributions of Radionuclides}

\subsubsection{Top reflector}

The radial distributions of radionuclides in the top reflector were measured at locations 22, 30, and $38 \mathrm{~cm}$ from the top of the element. Four radial cuts were made to a depth of about $1.8 \mathrm{~cm}$ to roughly define the radial distributions; the width of each cut was $1 / 2$ in. Tritium was measured in those samples taken from the $22 \mathrm{~mm}$ position. The only gamma emitters found in the top reflector were ${ }^{60} \mathrm{Co}, 13{ }^{4} \mathrm{Cs}$, and ${ }^{137} \mathrm{Cs}$. The results are presented in Table 4.15 .

Table 4.15. Radial distributions of radionculides found in the top reflector

(Data reported in microcuries per gram)

\begin{tabular}{cccccc}
\hline $\operatorname{Radius}_{(\mathrm{cm})}{ }^{2}$ & Thickness $^{b}$ & \multicolumn{3}{c}{ Radionuclide } \\
\cline { 3 - 5 } & $(\mathrm{cm})$ & $3_{\mathrm{H}}$ & ${ }^{60} \mathrm{Co}$ & ${ }^{134} \mathrm{Cs}$ & ${ }^{137} \mathrm{Cs}$
\end{tabular}

\begin{tabular}{|c|c|c|c|c|c|}
\hline \multicolumn{6}{|c|}{$22 \mathrm{~cm}$ from top of element } \\
\hline $\begin{array}{l}4.3752 \\
4.2227 \\
3.8672 \\
3.1052\end{array}$ & $\begin{array}{l}0.1016 \\
0.2032 \\
0.508 \\
1.016\end{array}$ & $\begin{array}{l}1.3 \\
0.2 \\
0.7 \\
0.4\end{array}$ & $\begin{array}{l}0.13 \\
0.002 \\
0.0009 \\
0.14\end{array}$ & $\begin{array}{l}0.0083 \\
0.00035 \\
0.00011 \\
0.009\end{array}$ & $\begin{array}{l}0.0067 \\
0.0012 \\
0.00019 \\
0.0086\end{array}$ \\
\hline \multicolumn{6}{|c|}{$30 \mathrm{~cm}$ from top of element } \\
\hline $\begin{array}{l}4.3752 \\
4.2227 \\
3.8672 \\
3.1052\end{array}$ & $\begin{array}{l}0.1016 \\
0.2032 \\
0.508 \\
1.016\end{array}$ & $\begin{array}{l}N^{c} \\
N^{c} \\
N^{C} \\
N^{c}\end{array}$ & $\begin{array}{l}0.11 \\
0.079 \\
0.0033 \\
0.0019\end{array}$ & $\begin{array}{l}0.0012 \\
0.00078 \\
0.00035 \\
0.0025\end{array}$ & $\begin{array}{l}0.0060 \\
0.0037 \\
0.00021 \\
0.011\end{array}$ \\
\hline \multicolumn{6}{|c|}{$38 \mathrm{~cm}$ from top of element } \\
\hline $\begin{array}{l}4.3752 \\
4.2227 \\
3.8672 \\
3.1052\end{array}$ & $\begin{array}{l}0.1016 \\
0.2032 \\
0.508 \\
1.016\end{array}$ & $\begin{array}{l}N^{C} \\
N_{C}^{C} \\
N^{c} \\
N^{c}\end{array}$ & $\begin{array}{l}0.28 \\
0.0037 \\
0.0028 \\
0.29\end{array}$ & $\begin{array}{l}0.0014 \\
0.00059 \\
0.00028 \\
0.0026\end{array}$ & $\begin{array}{l}0.0036 \\
0.0014 \\
0.00052 \\
0.0055\end{array}$ \\
\hline
\end{tabular}

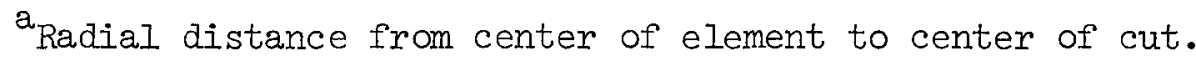

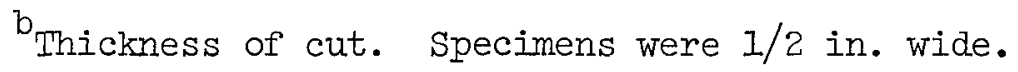

$c_{N}$ denotes that no measurement was made. 


\subsubsection{Spine}

The radial distributions of radionuclides in the spine were measured at locations adjacent to compacts 7, 16, and 26. Samples were taken on a lathe (as described in Sect. 3.7) on 1/2-in.-wide specimens cut from the indicated locations. Six cuts were made at compact positions 7 and 26 ; seven cuts were made at position 16 . The observed concentrations, in microcuries per gram, are presented in Tables 4.16-4.18.

The radionuclides ${ }^{3} \mathrm{H},{ }^{60} \mathrm{Co},{ }^{134} \mathrm{Cs}$, and ${ }^{137} \mathrm{Cs}$ were found to be radially distributed throughout the spine; however, ${ }^{95} \mathrm{Zr},{ }^{106} \mathrm{Ru},{ }^{144} \mathrm{Ce}$, and ${ }^{154} \mathrm{Eu}$ were present essentially on the surface. Silver-110m was found only to a depth of about $1 / 2 \mathrm{~cm}$ at compact positions 16 and 26 but was distributed throughout the spine opposite compact 7 . It is important to note that milling of the spine was done from the outside inward, which is in the direction of decreasing radionuclide concentrations. The marked decrease in activity indicates that, at least in some instances, the much loweractivity, inner samples may have been contaminated with the higher-activity, outer material. Therefore, intersample contamination may have caused biased results in the radial distributions and could be responsible for such observations as an increase of ${ }^{110 \mathrm{~m}_{\mathrm{Ag}}}$ near the center of the spine opposite compact 7 .

The radial distributions of ${ }^{134} \mathrm{Cs}$ and ${ }^{137} \mathrm{Cs}$ are shown in Figs. 4.13 and 4.14 respectively. As can be seen, the distributions at compact locations 7 and 16 are similar, whereas the distribution opposite compact 26 does not decrease as much as at the other two locations. This effect is particularly evident for ${ }^{134} \mathrm{Cs}$. As noted above, one must consider the possibility that intersample contamination could have caused significant errors in the method employed for taking the radial samples. Improved methods for acquiring radial samples from the spine are being devised for use on subsequent PIE's.

\section{$4.3 \cdot 3$ Sleeve}

The radial distributions of radionuclides found in the sleeve opposite compact locations 7, 16, and 26 are presented in Tables 4.19-4.21. The 
Table 4.16. Radial distributions of radionuclides in EO6-O1 spine at compact 7 (Data reported as microcuries/gram, corrected to January 6, 1972)

\begin{tabular}{|c|c|c|c|c|c|c|c|c|}
\hline \multirow{2}{*}{$\underset{(\mathrm{cm})}{\operatorname{Radius}}$} & \multirow{2}{*}{$\begin{array}{l}\text { Thickness } \\
\text { (cm) }\end{array}$} & \multicolumn{7}{|c|}{ Radionuclide } \\
\hline & & $\overline{6 \mathrm{O}_{\mathrm{CO}}}$ & ${ }^{106} \mathrm{Ru}$ & $110 \mathrm{~m}_{\mathrm{Ag}}$ & $134 \mathrm{Cs}$ & $137 \mathrm{Cs}$ & ${ }^{144} \mathrm{Ce}$ & $3_{\mathrm{H}}$ \\
\hline 2.013 & 0.159 & 0.236 & 17.7 & 84.5 & 10.9 & 12.9 & 12.3 & 3.06 \\
\hline 1.807 & 0.254 & 0.135 & 0.48 & 2.76 & 1.59 & 1.85 & 1.51 & 1.63 \\
\hline 1.521 & 0.318 & 0.125 & 0.61 & 3.86 & 0.66 & 0.75 & 1.25 & 1.07 \\
\hline 1.204 & 0.318 & 0.121 & & 0.00 & 0.070 & 0.07 & 0.00 & 1.07 \\
\hline 0.886 & 0.318 & 0.118 & & 0.07 & 0.029 & 0.03 & 0.00 & 1.06 \\
\hline 0.364 & 0.727 & 0.125 & & 0.71 & 0.097 & 0.11 & 0.41 & 0.90 \\
\hline
\end{tabular}

${ }_{b}^{a}$ Radius of center of milled section from center of spine.

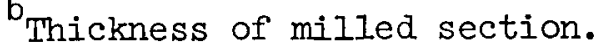

Table 4.17. Radial distributions of radionuclides in E06-01 spine at compact 16

(Data reported as microcuries/gram, corrected to January 6, 1972)]

\begin{tabular}{|c|c|c|c|c|c|c|c|c|c|}
\hline \multirow{2}{*}{${ }_{(\mathrm{cm})}^{\text {Radius }}{ }^{\mathrm{a}}$} & \multirow{2}{*}{$\begin{array}{c}\text { Thickness } \\
(\mathrm{cm})\end{array}$} & \multicolumn{8}{|c|}{ Radionuclide } \\
\hline & & $60_{\mathrm{Co}}$ & ${ }^{106} \mathrm{Ru}$ & $110 \mathrm{~m}_{\mathrm{Ag}}$ & $134 \mathrm{Cs}$ & $137_{\mathrm{Cs}}$ & ${ }^{144} \mathrm{Ce}$ & $154_{\mathrm{Eu}}$ & $3_{H}$ \\
\hline 2.017 & 0.159 & 3.71 & 5.90 & 14.4 & 6.66 & 7.88 & 34.30 & 1.43 & 2.91 \\
\hline 1.811 & 0.254 & 0.34 & 0.71 & 3.38 & 1.93 & 2.18 & 2.91 & 0.091 & 1.80 \\
\hline 1.525 & 0.318 & 0.077 & 0.00 & 0.34 & 0.342 & 0.342 & 0.00 & 0.00 & 1.44 \\
\hline 1.207 & 0.318 & 0.083 & 0.00 & 0.0 & 0.093 & 0.086 & 0.00 & 0.00 & 1.16 \\
\hline 0.890 & 0.318 & 0.088 & 0.00 & 0.0 & 0.032 & 0.031 & 0.00 & 0.00 & 0.87 \\
\hline 0.572 & 0.318 & 0.165 & 0.00 & 0.0 & 0.162 & 0.214 & 0.00 & 0.00 & 1.11 \\
\hline 0.207 & 0.414 & 0.142 & 0.00 & 0.0 & 0.036 & 0.039 & 0.00 & 0.00 & 1.17 \\
\hline
\end{tabular}

${ }_{b}$ Radius of center of milled section from center of spine.

Thickness of milled section. 
Table 4.18. Radial distributions of radionuclides in E06-01 spine at compact 26 (Data reported as microcuries/gram, corrected to January 6, 1972)

\begin{tabular}{|c|c|c|c|c|c|c|c|c|c|}
\hline \multirow{2}{*}{$\begin{array}{l}\text { Radius }^{a} \\
(\mathrm{~cm})\end{array}$} & \multirow{2}{*}{$\begin{array}{l}\text { Thickness } \\
\text { (cm) }\end{array}$} & \multicolumn{8}{|c|}{ Radionuclide } \\
\hline & & ${ }^{60} \mathrm{Co}$ & $106 \mathrm{Ru}$ & IIOM $_{\mathrm{Ag}}$ & ${ }^{134} \mathrm{Cs}$ & $137_{\mathrm{Cs}}$ & ${ }^{144} \mathrm{Ce}$ & $154_{\mathrm{Eu}}$ & $3_{\mathrm{H}}$ \\
\hline 1.930 & 0.235 & 1.55 & 5.64 & 0.75 & 4.09 & 5.72 & 66.03 & 0.00 & 1.44 \\
\hline 1.730 & 0.178 & 3.25 & 0.00 & 1.95 & 5.21 & 4.72 & 0.00 & 0.00 & 1.00 \\
\hline 1.490 & 0.318 & 0.58 & 0.00 & 0.19 & 0.96 & 0.26 & 0.00 & 0.00 & 0.70 \\
\hline 1.170 & 0.318 & 0.29 & 0.00 & 0.00 & 0.72 & 0.27 & 0.00 & 0.00 & 0.63 \\
\hline 0.851 & 0.318 & 0.15 & 0.0 & 0.0 & 0.62 & 0.12 & 0.00 & 1.15 & 0.51 \\
\hline 0.346 & 0.692 & 0.13 & 0.0 & 0.0 & 0.72 & 0.24 & 0.00 & 1.16 & 0.42 \\
\hline
\end{tabular}

${ }^{a}$ Radius of center of milled section from center of spine.

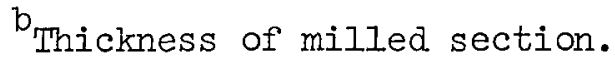




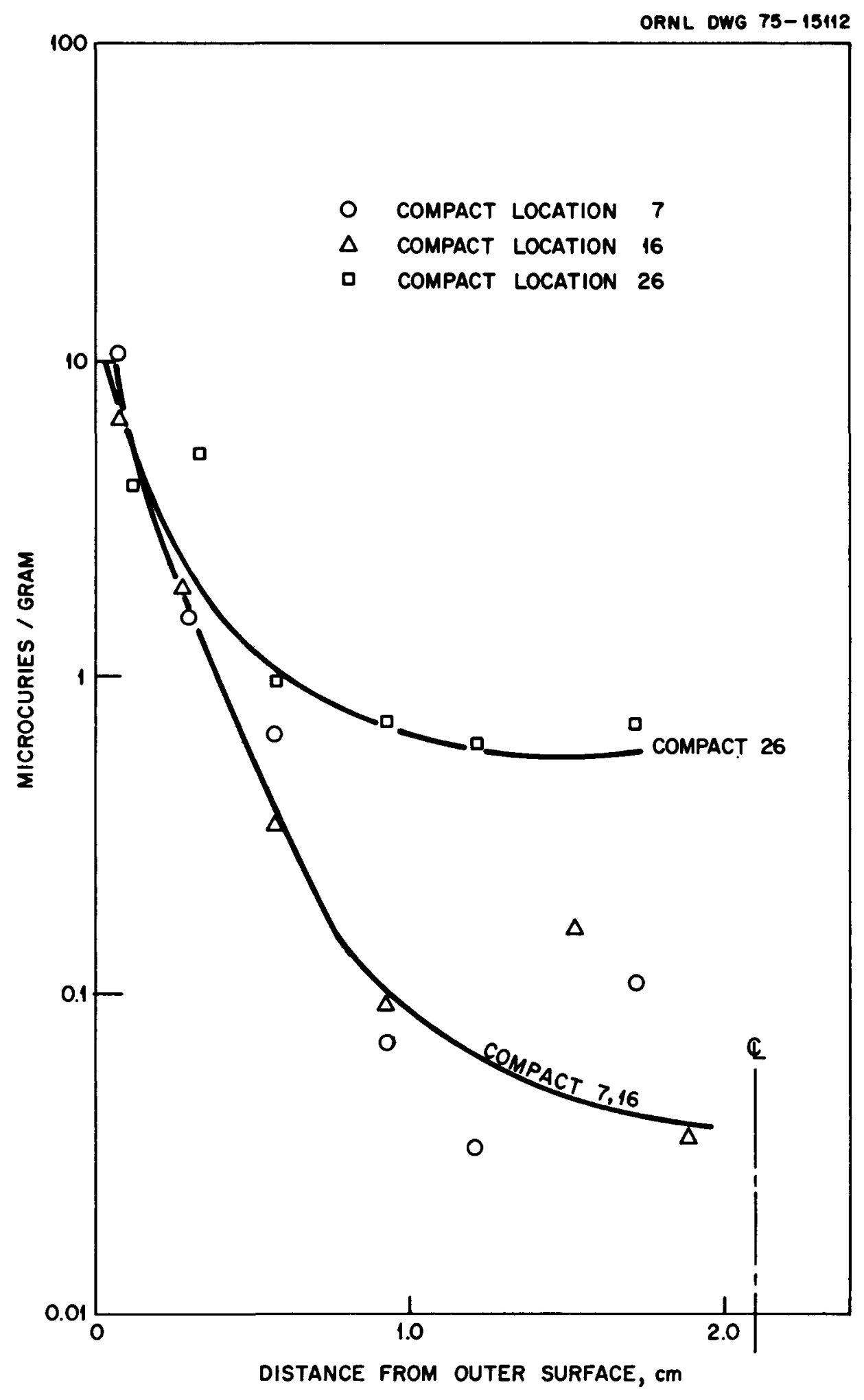

Fig. 4.13. Radial distributions of ${ }^{134} \mathrm{Cs}$ in EO6-OI spine. 


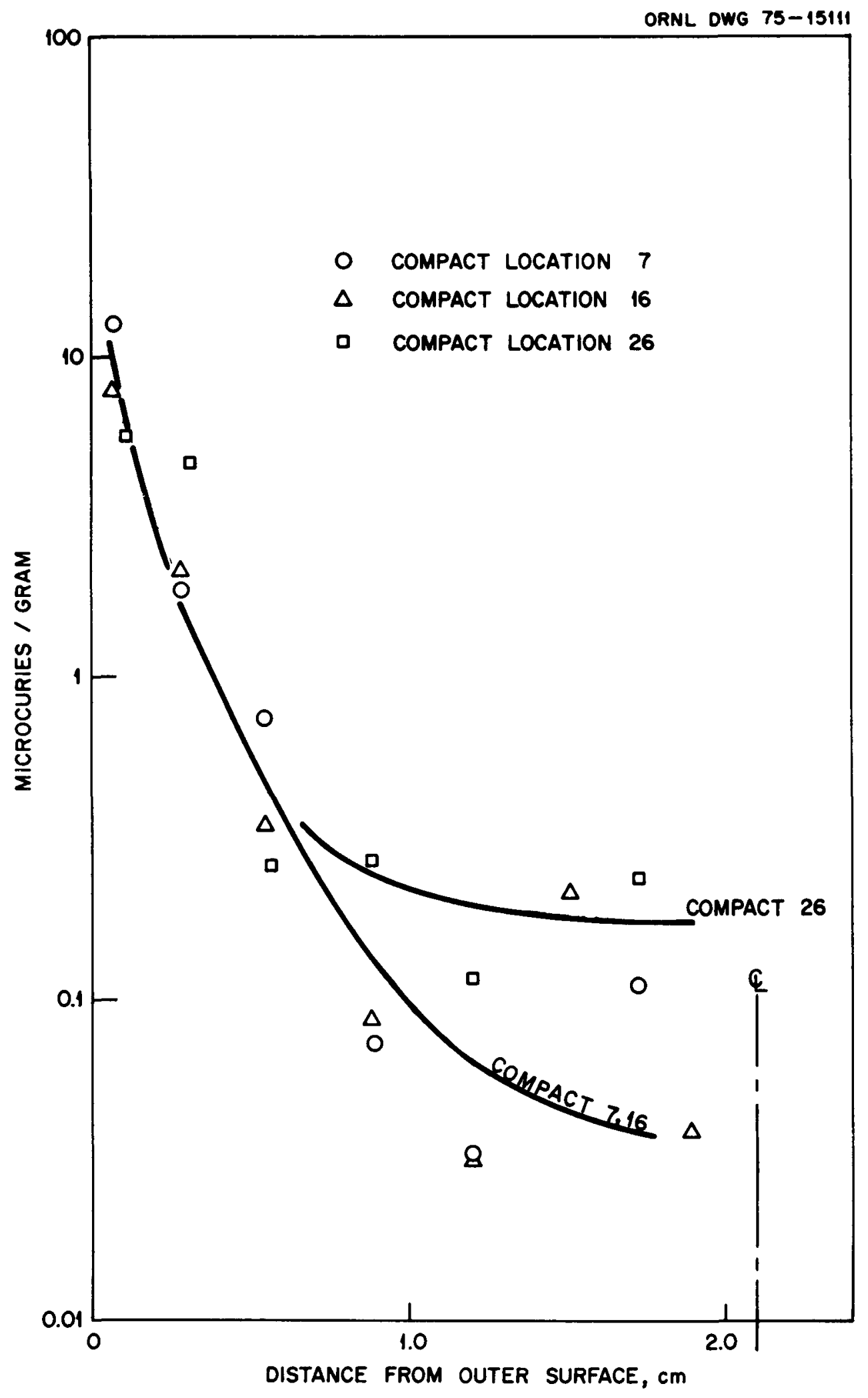

Fig. 4.14. Radial distributions of ${ }^{137} \mathrm{Cs}$ in E06-01 spine. 
Table 4.19. Radial distributions of radionuclides in EO6-Ol sleeve at compact 7 (Data reported as microcuries/gram, corrected to January 6, 1972)

\begin{tabular}{|c|c|c|c|c|c|c|c|c|}
\hline \multirow{2}{*}{$\begin{array}{c}\overline{\text { Radius }}{ }^{a} \\
(\mathrm{~cm})\end{array}$} & \multirow{2}{*}{$\begin{array}{l}\text { Thickness } \\
\quad(\mathrm{cm})\end{array}$} & \multicolumn{7}{|c|}{ Radionuclide } \\
\hline & & ${ }^{6 \mathrm{O}_{\mathrm{CO}}}$ & $110 \mathrm{~m}_{\mathrm{Ag}}$ & $134 \mathrm{Cs}$ & $137_{\mathrm{Cs}}$ & ${ }^{144} \mathrm{Ce}$ & $154 \mathrm{Eu}$ & $3_{\mathrm{H}}$ \\
\hline 4.391 & 0.064 & 1.99 & 0.26 & 0.064 & 0.057 & 0.498 & 0.613 & 10 \\
\hline 4.328 & 0.064 & 0.759 & 0.0 & 0.014 & 0.020 & 0.000 & 0.614 & 8.32 \\
\hline 4.245 & 0.102 & 0.762 & 0.0 & 0.016 & 0.019 & 0.053 & 0.569 & 6.44 \\
\hline 4.144 & 0.102 & 0.859 & 0.0 & 0.020 & 0.030 & 0.142 & 0.582 & 6.72 \\
\hline 4.042 & 0.102 & 0.902 & 0.0 & 0.049 & 0.055 & 0.082 & 0.523 & 6.84 \\
\hline 3.940 & 0.102 & 0.886 & 0.0 & 0.112 & 0.131 & 0.000 & 0.531 & 6.68 \\
\hline 3.839 & 0.102 & 0.816 & 0.0 & 0.280 & 0.309 & 0.143 & 0.531 & 5.04 \\
\hline 3.737 & 0.102 & 0.739 & 0.0 & 0.652 & 0.745 & 0.000 & 0.496 & 10.5 \\
\hline 3.636 & 0.102 & 0.767 & 0.0 & 1.73 & 2.69 & 0.319 & 0.443 & 28.7 \\
\hline 3.539 & 0.092 & 2.71 & 44.5 & 13.6 & 16.72 & 41.1 & 0.372 & 45.6 \\
\hline
\end{tabular}

${ }^{a}$ Radius from center of element.

Thickness of sample milled from sleeve. 
Table 4.20. Radial distributions of radionuclides in E06-01 sleeve at compact 16 (Data reported as microcuries/gram, corrected to January 6, 1972)

\begin{tabular}{|c|c|c|c|c|c|c|c|c|}
\hline \multirow{2}{*}{${ }_{(\mathrm{cm})}^{\text {Radius }^{2}}$} & \multirow{2}{*}{$\begin{array}{l}\text { Thickness } \\
(\mathrm{cm})\end{array}$} & \multicolumn{7}{|c|}{ Radionuclide } \\
\hline & & $\overline{{ }^{60} \mathrm{Co}}$ & $110 \mathrm{~m}_{\mathrm{Ag}}$ & $134 \mathrm{Cs}$ & $137 \mathrm{Cs}$ & ${ }^{144} \mathrm{Ce}$ & $154_{\mathrm{Eu}}$ & $3_{H}$ \\
\hline 4.394 & 0.064 & 2.24 & 0.19 & 0.068 & 0.109 & 0.267 & 0.713 & 28.5 \\
\hline 4.330 & 0.064 & 0.987 & 0.0 & 0.069 & 0.068 & 0.0 & 0.691 & 25.0 \\
\hline 4.248 & 0.102 & 0.903 & 0.0 & 0.121 & 0.108 & 0.103 & 0.652 & 19.5 \\
\hline 4.146 & 0.102 & 1.05 & 0.0 & 0.193 & 0.189 & 0.088 & 0.619 & 17.2 \\
\hline 4.045 & 0.102 & 1.14 & 0.0 & 0.360 & 0.341 & 0.079 & 0.603 & 15.5 \\
\hline 3.943 & 0.102 & 1.19 & 0.0 & 0.726 & 0.713 & 0.119 & 0.604 & 16.9 \\
\hline 3.842 & 0.102 & 1.08 & 0.0 & 1.57 & 1.65 & 0.0 & 0.584 & 15.7 \\
\hline 3.740 & 0.102 & 1.01 & 0.0 & 3.39 & 3.70 & 0.0 & 0.544 & 10.3 \\
\hline 3.591 & 0.196 & 2.42 & 85.3 & 15.9 & 19.9 & 17.3 & 0.619 & 11.3 \\
\hline
\end{tabular}

${ }^{a}$ Radius from center of element

$\mathrm{b}_{\text {Thickness of sample milled from sleeve. }}$ 
Table 4.21. Radial distributions of radionuclides in E06-01 sleeve at compact 26 (Data reported as microcuries/gram, corrected to January 6, 1972)

\begin{tabular}{|c|c|c|c|c|c|c|c|c|}
\hline \multirow{2}{*}{$\underset{(\mathrm{cm})}{\operatorname{Radius}}$} & \multirow{2}{*}{$\begin{array}{l}\text { Thickness } \\
(\mathrm{cm})\end{array}$} & \multicolumn{7}{|c|}{ Radionuclide } \\
\hline & & $60_{\mathrm{CO}}$ & $110 m_{A g}$ & ${ }^{134} \mathrm{Cs}$ & $137_{\mathrm{CS}}$ & ${ }^{14} \mathrm{Ce}$ & ${ }^{154_{\mathrm{Eu}}}$ & $3_{\mathrm{H}}$ \\
\hline 4.392 & 0.064 & 1.57 & 0.0 & 0.025 & 0.034 & 0.0 & 0.596 & 9.48 \\
\hline 4.329 & 0.064 & 0.786 & 0.0 & 0.039 & 0.055 & 0.0 & 0.577 & 7.72 \\
\hline 4.246 & 0.102 & 0.777 & 0.0 & 0.076 & 0.096 & 0.0 & 0.541 & 5.71 \\
\hline 4.145 & 0.102 & 0.882 & 0.0 & 0.118 & 0.160 & 0.0 & 0.531 & 5.65 \\
\hline 4.043 & 0.102 & 0.958 & 0.0 & 0.184 & 0.255 & 0.0 & 0.531 & 4.16 \\
\hline 3.942 & 0.102 & 1.02 & 0.0 & 0.317 & 0.429 & 0.0 & 0.508 & 3.52 \\
\hline 3.840 & 0.102 & 0.939 & 0.0 & 0.526 & 0.739 & 0.0 & 0.499 & 3.89 \\
\hline 3.738 & 0.102 & 0.824 & 0.0 & 0.800 & 1.16 & 0.0 & 0.495 & 4.31 \\
\hline 3.637 & 0.102 & 0.875 & 0.0 & 0.831 & 1.19 & 0.2 & 0.490 & 4.41 \\
\hline 0.540 & 0.092 & 1.51 & 65. & 1.1 .2 & 18.5 & 86.7 & 0.421 & 6.02 \\
\hline
\end{tabular}

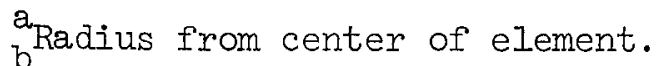

Thickness of sample milled from sleeve. 
sampling procedure is described in sect. 3.7; ten samples were taken at compact 16 .

The radionuclides ${ }^{3} \mathrm{H},{ }^{60} \mathrm{Co},{ }^{134} \mathrm{Cs},{ }^{137} \mathrm{Cs}$, and ${ }^{154} \mathrm{Eu}$ were distributed. throughout the sleeve radius, while ${ }^{11.0 m} \mathrm{Ag}$ was found primarily on the inner surface. Cerium-144, which presented an intermediate situation, was found mainly on the surface of the inner sleeve; much smaller levels were distributed radially. It should be noted that the radial milling was done from the less-radioactive, outer surface to the more-radioactive, inner surface; thus intersample contamination was much less likely for the sleeve than for the spine.

The radial distributions of ${ }^{134} \mathrm{Cs}$ and ${ }^{137} \mathrm{Cs}$ in the sleeve are shown in Fig. 4.15. The ${ }^{137} \mathrm{Cs}$ nuclide is a direct fission product which decays from a xenon precursor having a half-life of $3.8 \mathrm{~min}$; ${ }^{134} \mathrm{Cs}$, on the other hand, develops by neutron absorption in ${ }^{13} \mathrm{Cs}$ following the decay of 133 Xe (half-life, 5.3 days). Hence the similarity of distributions of the two radionuclides of cesium indicates that xenon precursor transport is insignificant in the determination of cesium distributions. The concentrations of both radionuclides at compact positions 16 and 26 are higher at larger penetrations than at compact position 7 , reflecting the effect of higher temperatures in the middle and top of the fueled region.

\subsection{Burnup Results}

As described in Sect. 3.9, FIMA determinations were made for particles from fuel compacts 18 and 27. The thorium and uranium contents in a few samples were measured by both spectrophotometry and IDMS (see Table 4.22).

FIMA is calculated according to:

$$
\text { FIMA }=\frac{\text { number of fissions }}{\text { Th atoms }+ \text { U atoms }+ \text { number of fissions }},
$$

where the denominator is equal to the initial number of heavy-metal atoms. Since the number of fissions can be computed by dividing the number of atoms of zirconium by its fission yield, $Y=0.31$, we can write: 


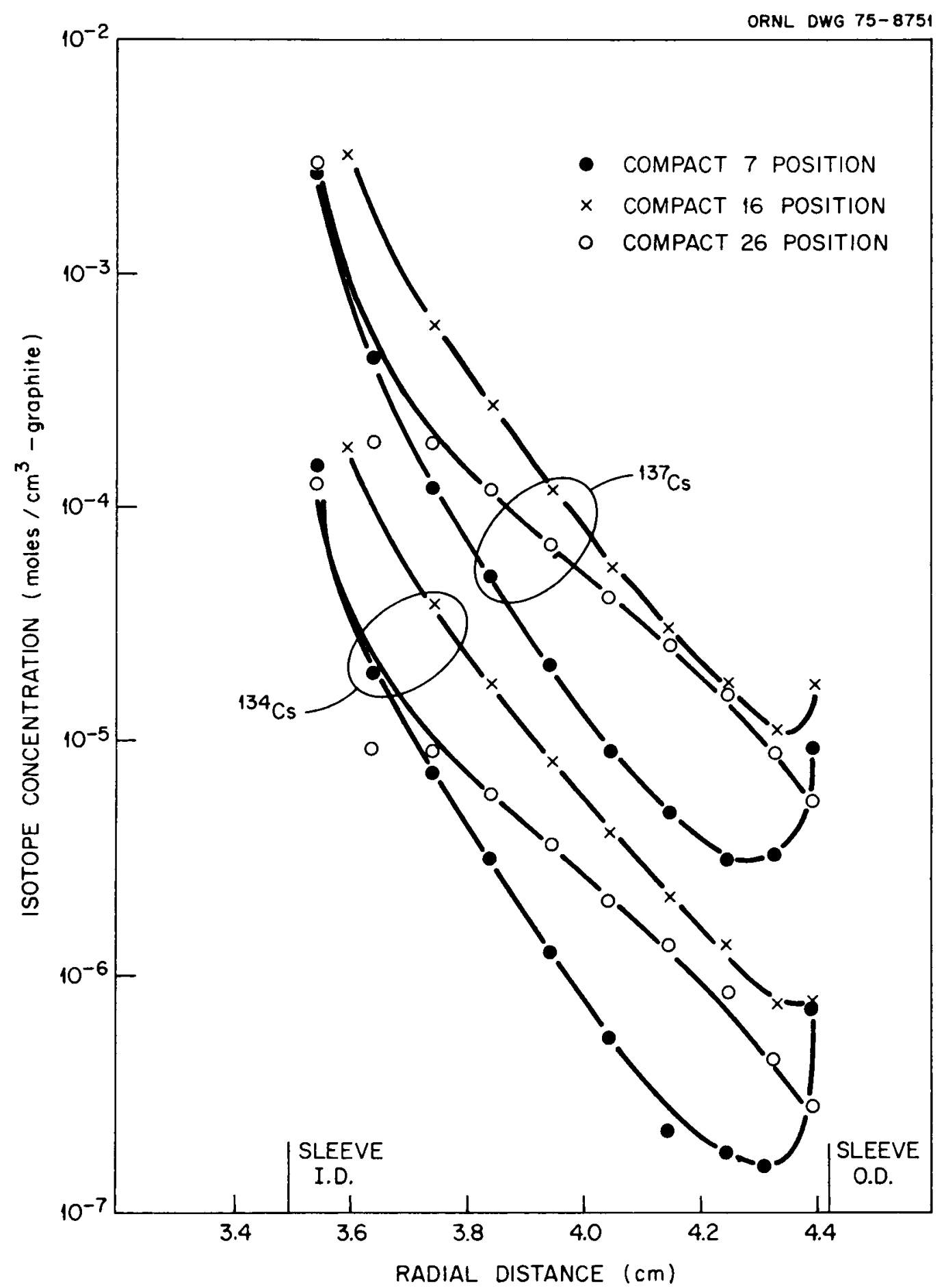

Fig. 4.15. Radial distributions of ${ }^{134} \mathrm{Cs}$ and ${ }^{137} \mathrm{Cs}$ in E06-01 sleeve. 
Table 4.22. Burnup (FTMA) and Th/U atom ratios for element E06-01

\begin{tabular}{|c|c|c|c|c|c|c|c|c|c|c|}
\hline \multirow{2}{*}{$\begin{array}{l}\text { Compact } \\
\text { number }\end{array}$} & \multirow{2}{*}{$\begin{array}{l}\text { Sample } \\
\text { number }\end{array}$} & \multicolumn{3}{|c|}{ Total found $(\mu g)$} & \multicolumn{3}{|c|}{ Th/U atom ratio } & \multicolumn{3}{|c|}{ Percent FIMA } \\
\hline & & Th & $\mathrm{U}$ & $\overline{Z x}$ & Spectrophotometry $\bar{b}$ & $I D M S^{C}$ & $\overline{G A U G E^{\mathrm{d}}}$ & $\mathrm{Zr}^{\mathrm{e}}$ & GAUGE $^{\mathrm{d}}$ & $137_{\mathrm{Cs}^{\mathrm{f}}}$ \\
\hline \multirow[t]{4}{*}{18} & 1 & 147 & 21.0 & 0.79 & 7.09 & & & 3.7 & & \\
\hline & 2 & $\begin{array}{l}180 \\
180^{c}\end{array}$ & $29.1^{c}$ & 0.95 & & 6.27 & & 3.6 & & \\
\hline & 3 & $\begin{array}{l}183 \\
186^{c}\end{array}$ & $29.9^{c}$ & 1.04 & & 6.30 & & 3.8 & & \\
\hline & & & & & & & Mean & 3.7 & $3 \cdot 5$ & 4.2 \\
\hline \multirow[t]{4}{*}{27} & 1 & 157 & 23.7 & 0.81 & 6.71 & & & 3.5 & & \\
\hline & 2 & $159^{112}$ & $25.9^{c}$ & 0.89 & & 6.22 & & 3.8 & & \\
\hline & 3 & $197^{c}$ & $32.6^{c}$ & 1.00 & & 6.12 & & 3.5 & & \\
\hline & & & & & & & Mean & 3.6 & 2.1 & 3.1 \\
\hline \multicolumn{2}{|c|}{ Total element } & & & & & & 6.1 & & 3.0 & 3.6 \\
\hline
\end{tabular}

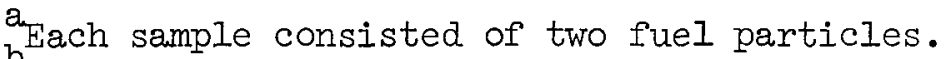

${ }^{b}$ Atom ratios were computed using 235.03 for an end-of-life atomic weight of uranium.

IDMS = isotope dilution mass spectrometry.

Taken from McCord (ref. 5).

FIMA computed using 235.03 and 91.22 for the end-of-life atomic weights of uranium and zirconium, respectively, where available.

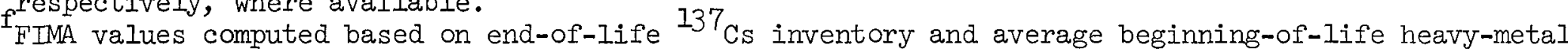
inventory. 


$$
\text { FIMA }=\frac{Z r \text { atoms } / Y}{\text { Th atoms }+U \text { atoms }+\frac{Z r \text { atoms }}{Y}} .
$$

The results (as percent FIMA) found by both methods are summarized in Table 4.22. Average values found were 3.7 and $3.6 \%$ for compacts 18 and 27 respectively. The Th/U atom ratios are also summarized in Table 4.22 .

It should be noted that the Th/U ratio obtained by the spectrophotometric method for the first sample of both compacts is about $10 \%$ higher than that determined by IDMS for the other samples. Unfortunately, the uranium contents of samples 2 and 3 of each compact were not measured spectrophotometrically; thus it was impossible to obtain a good comparison of results from the two methods. FIMA values derived from results of the two methods were in fairly good agreement.

Two additional and independent estimates of FIMA were also made. For the first estimate, the EOL inventories of heavy-metal atoms in each compact and in the whole element were computed by McCord, ${ }^{5}$ using the GAC neutronic code GAUGE. The difference between beginning-of-life (BOI) and EOL inventories of heavy metals is equal to the number of fissions and was used by McCord to compute FIMA values of 3.49 and $2.10 \%$ for compacts 18 and 27 respectively. The average $T h / U$ atom ratio for the whole element calculated from the computed EOL heavy-metal inventories is 6.10. For the second estimate, the measured EOL inventory of ${ }^{13} 7_{\mathrm{Cs}}$ was used to compute FIMA values of 4.2 and $3.1 \%$ for compacts 18 and 27 using data in Table 4.9. That ${ }^{137} \mathrm{Cs}$ is a valid fuel-burnup monitor for E06-0I is seen from the following arguments:

(1) The half-life of $137_{\mathrm{CS}}$ is sufficiently long (30 years) to integrate the fission rate over the 384 days of operation.

(2) Very little ${ }^{137} C_{\text {s }}$ was found in the nonfuel components of the element, indicating little escape of cesium from the fuel.

(3) As shown by Turner et al., ${ }^{3}$ very little of the ${ }^{137}$ Xe $\left({ }^{137}\right.$ Cs precursor) escaped from Core 2 fuel elements. 


\subsection{Comparison of Measured and Calculated Fission} Product Inventories

Early in the examination of EO6-OI, Tobias ${ }^{9}$ reported a comparison of fission product inventories computed using the ORIGEN code with measured values obtained in the PIE. For convenience of reference, this comparison is presented in Table 4.23. As can be seen, the differences between calculated and measured inventories are fairly small, ranging from less than $1 \%$ for ${ }^{144} \mathrm{Ce}$ to $32 \%$ for ${ }^{125} \mathrm{Sb}$. It is interesting to note that, whereas the calculated amount of ${ }^{137} \mathrm{Cs}$ is $9.7 \%$ lower than that measured, the calculated inventory of ${ }^{134} \mathrm{Cs}$ is $25 \%$ higher than the experimental value. This result may be due to the much more complex mode of formation of ${ }^{134} \mathrm{Cs}$, namely:

$$
{ }^{235} \mathrm{U} \stackrel{\mathrm{n} . \mathrm{f} .}{\longrightarrow}{ }^{133} \mathrm{Cs} \stackrel{\mathrm{n}, \gamma}{\longrightarrow}{ }^{134} \mathrm{Cs} \text {. }
$$

This signifies the need for more accurately known irradiation conditions before the ${ }^{134} \mathrm{Cs}$ can be computed accurately.

\subsection{Summary of Radionuclide Inventories in Graphite Components}

The total inventories of radionuclides in the graphite components of E06-01, given in Tables 4.6, 4.7, 4.12, 4.13, and 4.14, are summarized in Table 4.24. In the last column, comparison is made with the total measured inventories in the 30 fuel compacts, as given in Table 4.8. As can be seen, the largest relative measured radionuclide level in the graphite parts of the fuel element is that for ${ }^{154} \mathrm{Eu}$, where $0.27 \%$ of the fuel inventory was found in the graphite. Most likely, this does not represent transport from the fuel but, rather, formation by neutron absorption in ${ }^{153} \mathrm{Eu}$ present as a trace element in graphite.

Except for the spurious ${ }^{154} \mathrm{Eu}$ levels, Table 4.24 indicates that cesium, as expected, is the most mobile fission product; it appears in the graphite to a level of $0.026 \%$ of the fuel inventory. The largest level of activity in the graphite portions of EO6-OI is seen to be that for ${ }^{144} \mathrm{Ce}$ (the second most mobile fission product), which exhibits a measured leakage of about $0.013 \%$ from the fuel to the graphite. 
Table 4.23. Comparison of computed and measured fission product inventories in E06-01 fuel

\begin{tabular}{|c|c|c|c|}
\hline \multirow{2}{*}{$\begin{array}{l}\text { Fission } \\
\text { product }\end{array}$} & \multicolumn{2}{|c|}{ Inventory ( $\mathrm{Ci})$} & \multirow{2}{*}{$\begin{array}{c}\text { Percent } \\
\text { Difference }\end{array}$} \\
\hline & Calculated ${ }^{2}$ & Measured & \\
\hline${ }^{85} \mathrm{Kr}$ & 264 & $N^{d}$ & \\
\hline${ }^{89} \mathrm{Sr}$ & 429 & $N^{\mathrm{d}}$ & \\
\hline $90_{\mathrm{Sr}}$ & 166 & $N^{d}$ & \\
\hline${ }^{95} \mathrm{Zr}$ & 5180 & 5640 & -8.2 \\
\hline${ }^{103} \mathrm{Ru}$ & 2660 & & \\
\hline${ }^{106} \mathrm{Ru}$ & 196 & 230 & -15 \\
\hline $110 \mathrm{~m}_{\mathrm{Ag}}$ & 0.224 & $\mathrm{~N}^{\mathrm{d}}$ & \\
\hline${ }^{I I I} \mathrm{Ag}$ & 24.7 & $N^{d}$ & \\
\hline $125_{\mathrm{Sb}}$ & 6.4 & 9.4 & -32 \\
\hline $127 \mathrm{~m}_{\mathrm{Te}}$ & 29.9 & $N^{a}$ & \\
\hline${ }^{129} \mathrm{Te}$ & 1110. & $\mathrm{~N}^{\mathrm{d}}$ & \\
\hline $129_{\text {I }}$ & $5 . \mathrm{OE}-5$ & $\mathrm{~N}^{\mathrm{d}}$ & \\
\hline $13 I_{I}$ & 3340 & $N^{d}$ & \\
\hline${ }^{134} \mathrm{Cs}$ & 161 & 129 & 25 . \\
\hline $137 \mathrm{Cs}$ & 168 & 186 & -9.7 \\
\hline $14 \mathrm{O}_{\mathrm{Ba}}$ & 6950 & $N^{a}$ & \\
\hline${ }^{144} \mathrm{Ce}$ & 3180 & 3160 & 0.6 \\
\hline $152_{\mathrm{Eu}}$ & 0.019 & $N^{d}$ & \\
\hline $154 \mathrm{Eu}$ & $3 \cdot 3$ & 2.9 & 14. \\
\hline${ }^{155} \mathrm{Eu}$ & 3.94 & $N^{d}$ & \\
\hline
\end{tabular}

${ }_{b}^{a}$ Calculated by Tobias (see ref. 9).

Taken from Table 4.8 .

$c_{\%}$ Difference $=100\left(\frac{\text { calculated activity }}{\text { measured activity }}-1\right)$.

$\mathrm{d}_{\mathrm{N}}$ denotes either that no attempt was made to measure the nuclide or that its gamma rays were not detected. 
Table 4.24. Inventories of radionuclides in graphite components of element E06-01 ${ }^{\mathrm{a}}$

\begin{tabular}{|c|c|c|c|c|c|c|}
\hline \multirow[b]{2}{*}{ Radionuclide } & \multicolumn{5}{|c|}{ Inventory in component (mCi) } & \multirow[b]{2}{*}{$\begin{array}{c}\text { Percent of total fuel } \\
\text { inventory }\end{array}$} \\
\hline & $\begin{array}{c}\text { Top } \\
\text { reflector }\end{array}$ & Spine & Sleeve & $\begin{array}{l}\text { Bottom } \\
\text { reflector }\end{array}$ & Total & \\
\hline${ }^{46} \mathrm{Sc}$ & 4 & 11.1 & 62 & $\mathrm{~N}$ & 77 & \\
\hline${ }^{46} \mathrm{Co}$ & 0.8 & 3.7 & 10 & 1.9 & 16 & \\
\hline $95 \mathrm{zr}$ & $\mathrm{N}$ & 32. & 283 & N & 315 & 0.0056 \\
\hline${ }^{106} \mathrm{Ru}$ & $1.2 \mathrm{E}-4$ & 8.6 & 10 & 0.6 & 19 & 0.0083 \\
\hline $110 \mathrm{~m} A g$ & 0.09 & 17 & 55 & $\mathrm{~N}$ & 72 & 32.1 \\
\hline${ }^{134} \mathrm{Cs}$ & 0.06 & 10 & 24 & 1.1 & 35 & 0.027 \\
\hline${ }^{137} \mathrm{Cs}$ & 0.02 & 12 & 35 & 0.69 & 48 & 0.026 \\
\hline $144 \mathrm{Ce}$ & $3 E-4$ & 56 & 356 & 9.6 & 422 & 0.013 \\
\hline${ }^{154} \mathrm{Eu}$ & 0.25 & 3.8 & 4.2 & $\mathbb{N}$ & 8 & 0.27 \\
\hline $54 \mathrm{Mn}$ & $3.5 \mathrm{E}-4$ & $\mathbb{N}$ & $\mathbb{N}$ & $\mathrm{N}$ & $3.5 \mathrm{E}-4$ & \\
\hline $59_{\mathrm{Fe}}$ & 0.012 & $\mathbb{N}$ & $\mathrm{N}$ & $\mathbb{N}$ & 0.012 & \\
\hline${ }^{65} \mathrm{Zn}$ & $\mathrm{N}$ & $\mathbb{N}$ & $\mathrm{N}$ & 9.2 & 9.2 & \\
\hline $3_{\mathrm{H}}$ & I & 7.2 & 109 & $\mathrm{~N}$ & 116 & \\
\hline $90_{\mathrm{Sr}}$ & $I$ & 4.3 & 16 & $\mathrm{~N}$ & 20 & \\
\hline
\end{tabular}

${ }^{a}$ An entry of $\mathbb{N}$ instead of a numerical value in the table denotes either that no attempt was made to measure the radionuclides or that it was not detected by gamma spectroscopy. An entry of I denotes insufficient data to determine inventory.

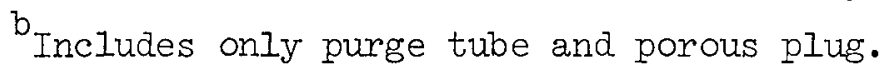

Includes only fission product trap. 


\subsection{Results of Metallographic Examinations}

Two cross-sectional planes in compact 17 were polished and photographed, and the exposed particles were examined for cracks that had developed in the coating as a result of irradiation. 10 Cracks that decreased in width away from the fuel kernel were assumed to be irradiation induced; other cracks were assumed to result from the fuel fabrication. Of a total of 350 particles examined, 11 (3.1\%) irradiation-induced coating failures were observed. It is interesting to note that, if the coating failure fraction in the whole element were $3.1 \%$, the total amount of ${ }^{137} \mathrm{Cs}$ in cracked particles would exceed $5 \mathrm{Ci}$. Since the nonfuel components of the element contained only $0.048 \mathrm{Ci}$ of $137 \mathrm{Cs}$ (see Table 4.24), evidently very little of the cesium migrated from the fuel compacts.

Photographs of a polished plane section of the fuel, matrix, and several particles are shown in Figs. 4.16-4.25. The polished plane section through compact 17, shown magnified about 18 times in Fig. 4.16, exhibits intact particles, particles whose kernels have fallen out (particles with dark centers) and spaces (dark areas) where whole particles have been lost from the matrix. Most of the photographs confirm that the matrix was in a good, undamaged condition; this is especially noted in Fig. 4.17, where the magnification is about 250x.

Fuel particles with intact coatings are shown in Figs. 4.18 and 4.19; however, in the latter case, a pronounced shrinkage from the matrix is evident. Figures 4.19-4.24 exhibit fuel particles with various degrees of coating failures. A cracked kernel, as well as a crack in the pyrocarbon (PyC) layer is seen in Fig. 4.20. Figure 4.22 illustrates a radiation-induced crack in the PyC layer under two magnifications. A cracked buffer layer and a damaged PyC coating are seen in Fig. 4.23. Two additional cases of PyC-failed fuel particles are shown in Fig. 4.24. Figure 4.25 illustrates an unusual shrinkage of the buffer layer away from the inner surface of the Pyc coating. 
PHOTO R63518

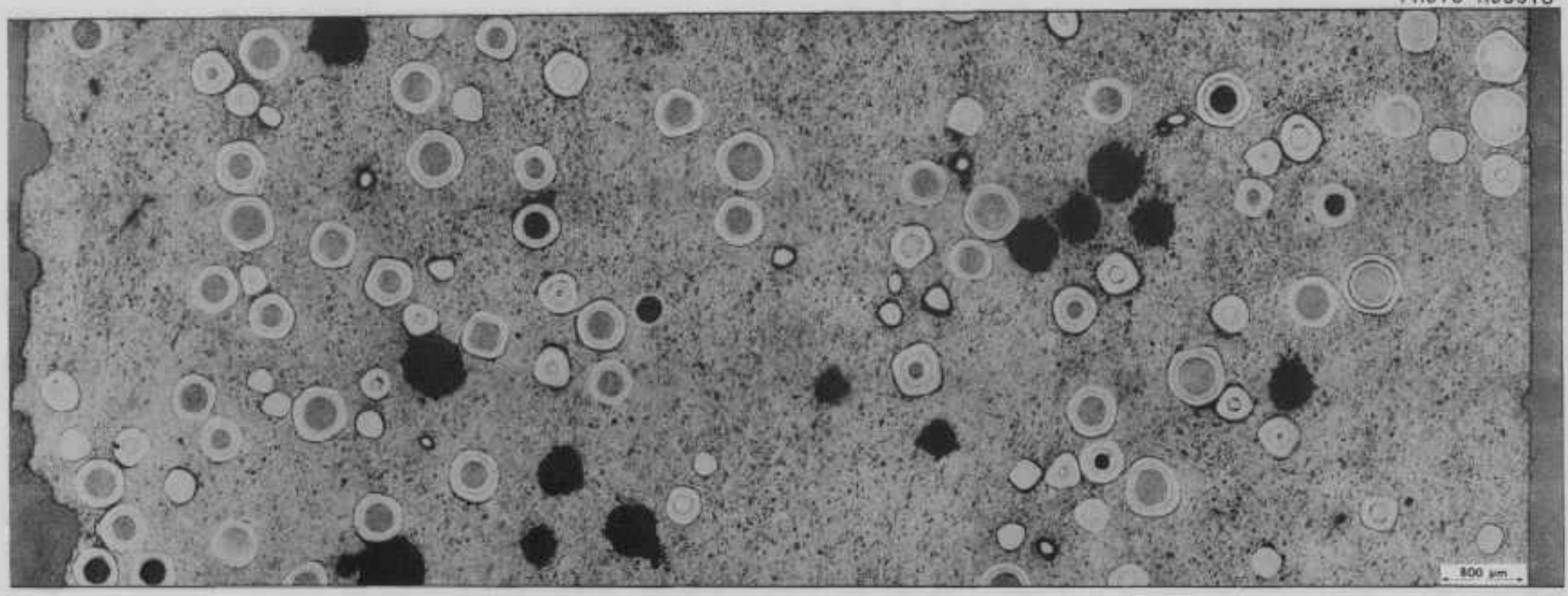

Fis. 4.16. Polished section soross compact 17, showing inner (left) and outer (right) diameters. Nagnification $18 x$. 

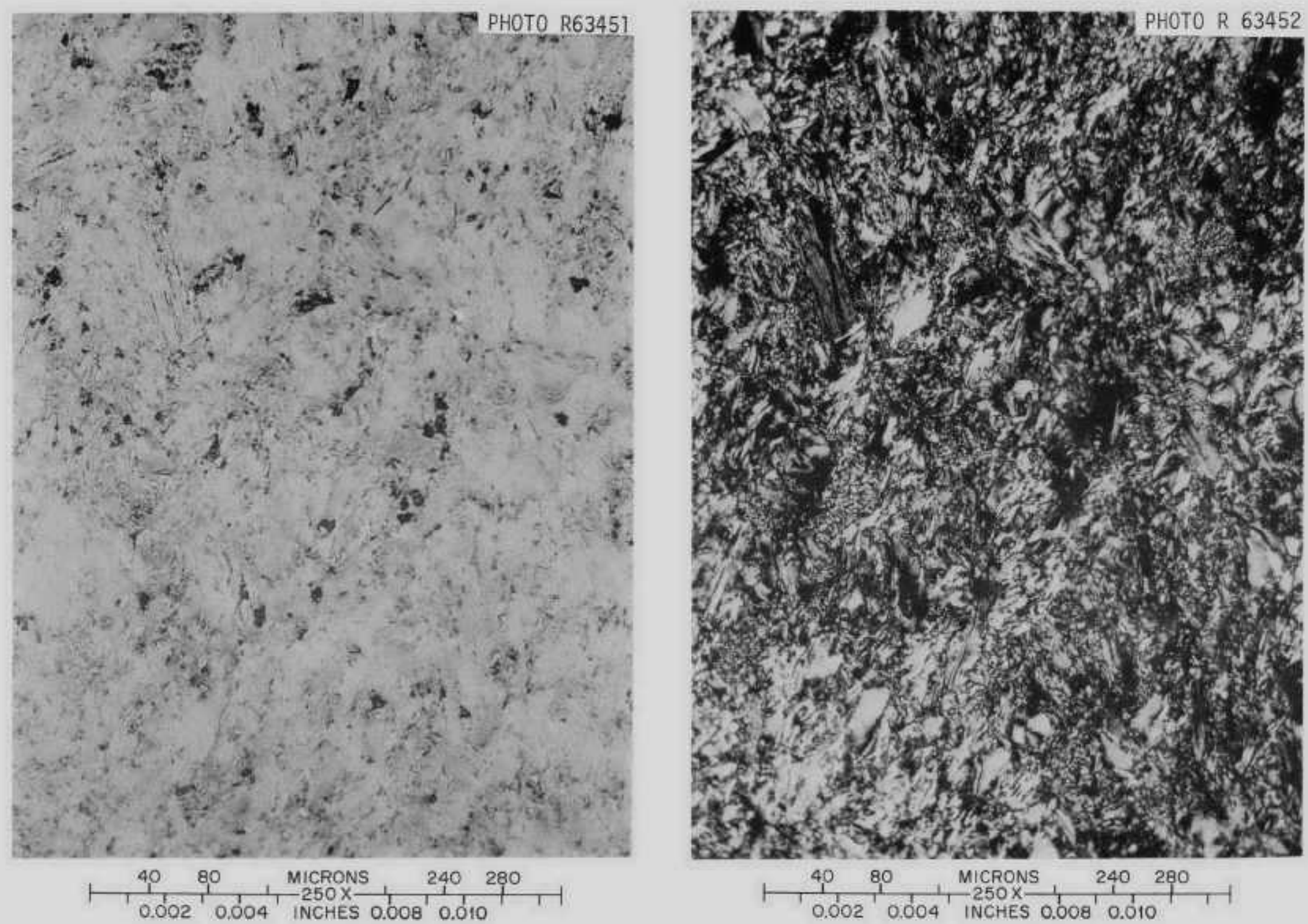

Fig. 4.17. Natrix or fuel compact 17 photographed with normal light (left) and polarized light (right). 

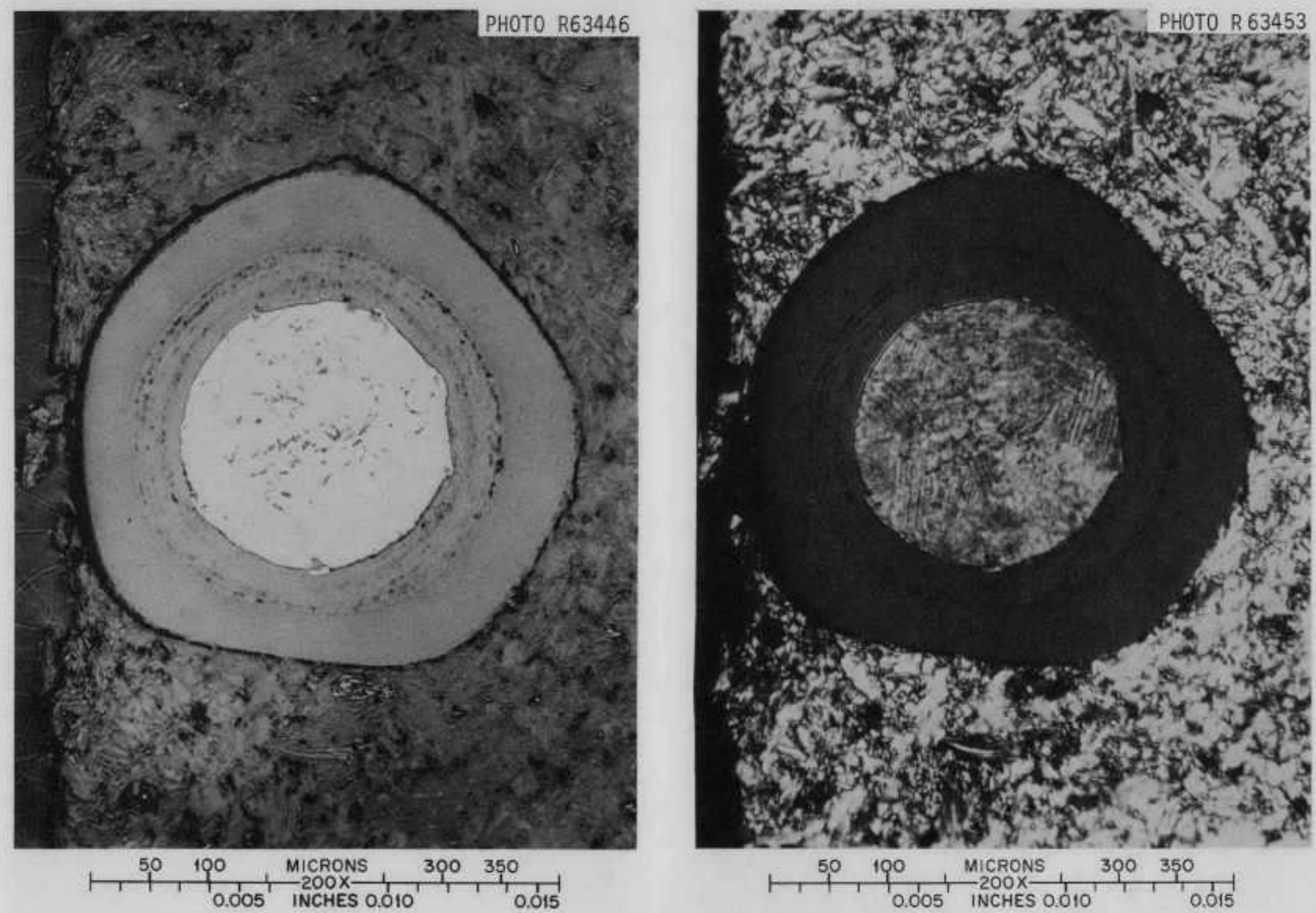

Fig. 4.18. Intact particle in compact 17 photographed with normal light (left) and polorized light (right). 

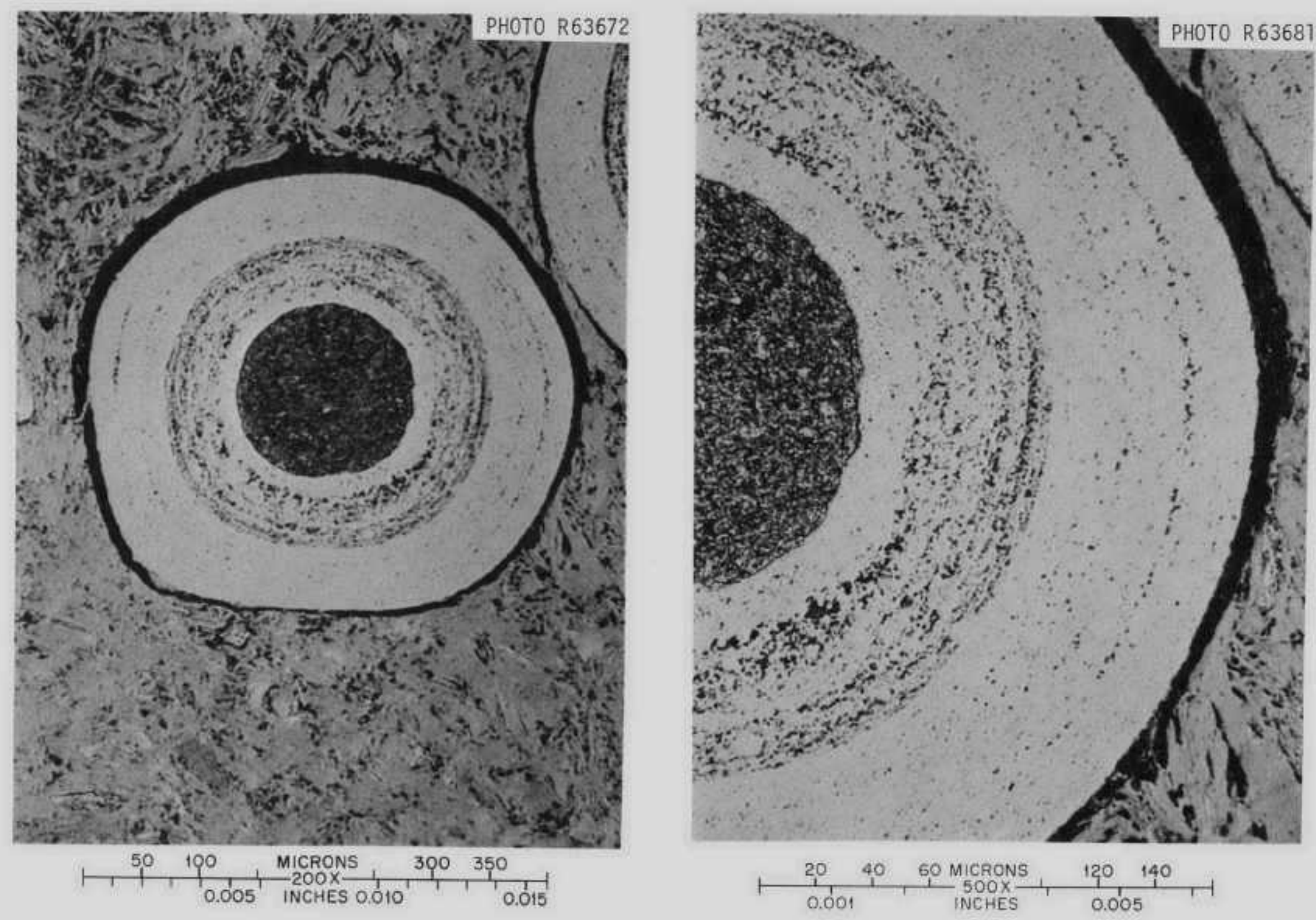

Tig. 4.19. Intact particle in compect 17, showing shrinkage

from matrix. 


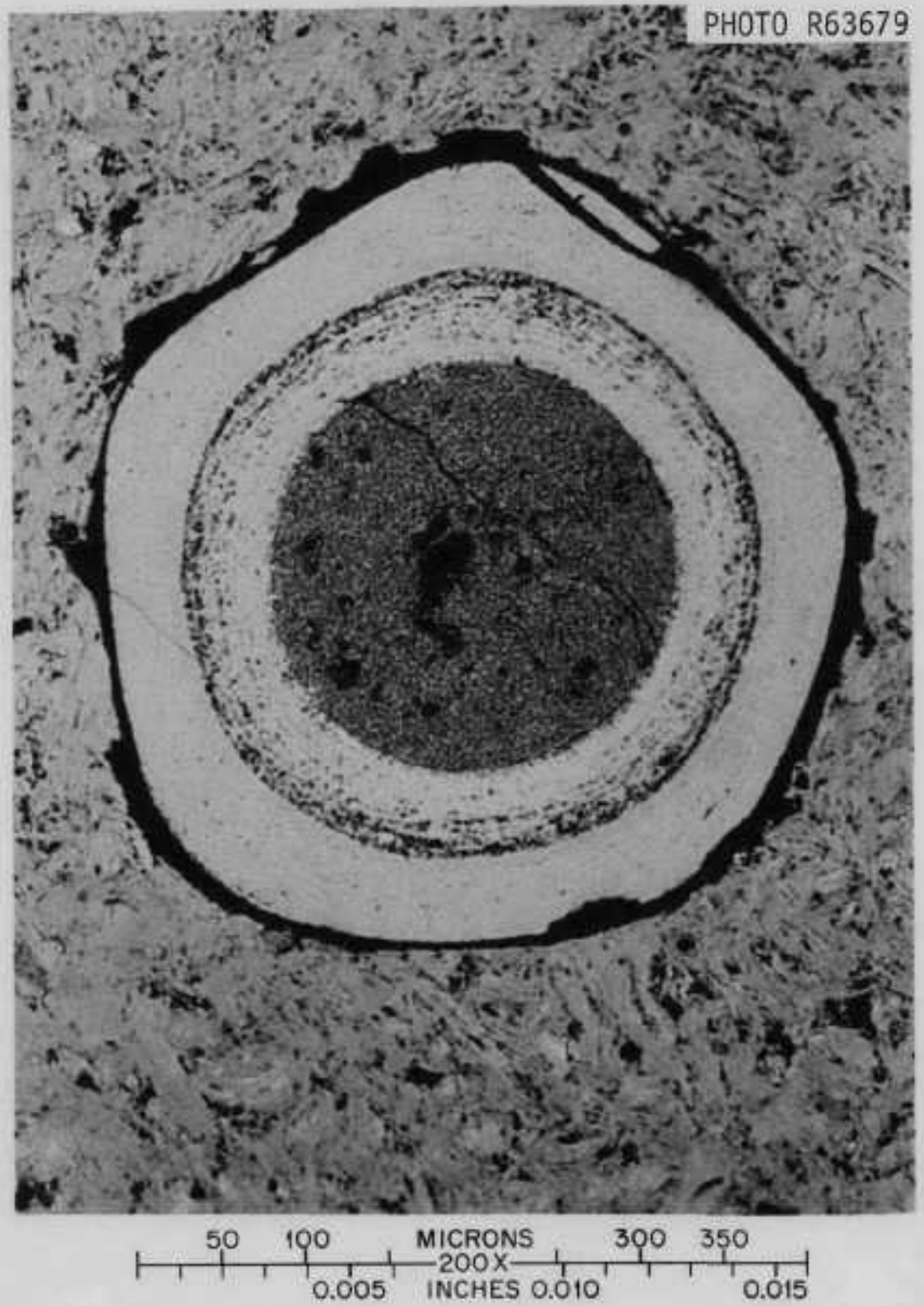

Fig. 4.20. Fuel particle, showing cracked kernel and shrinkage from matrix. 


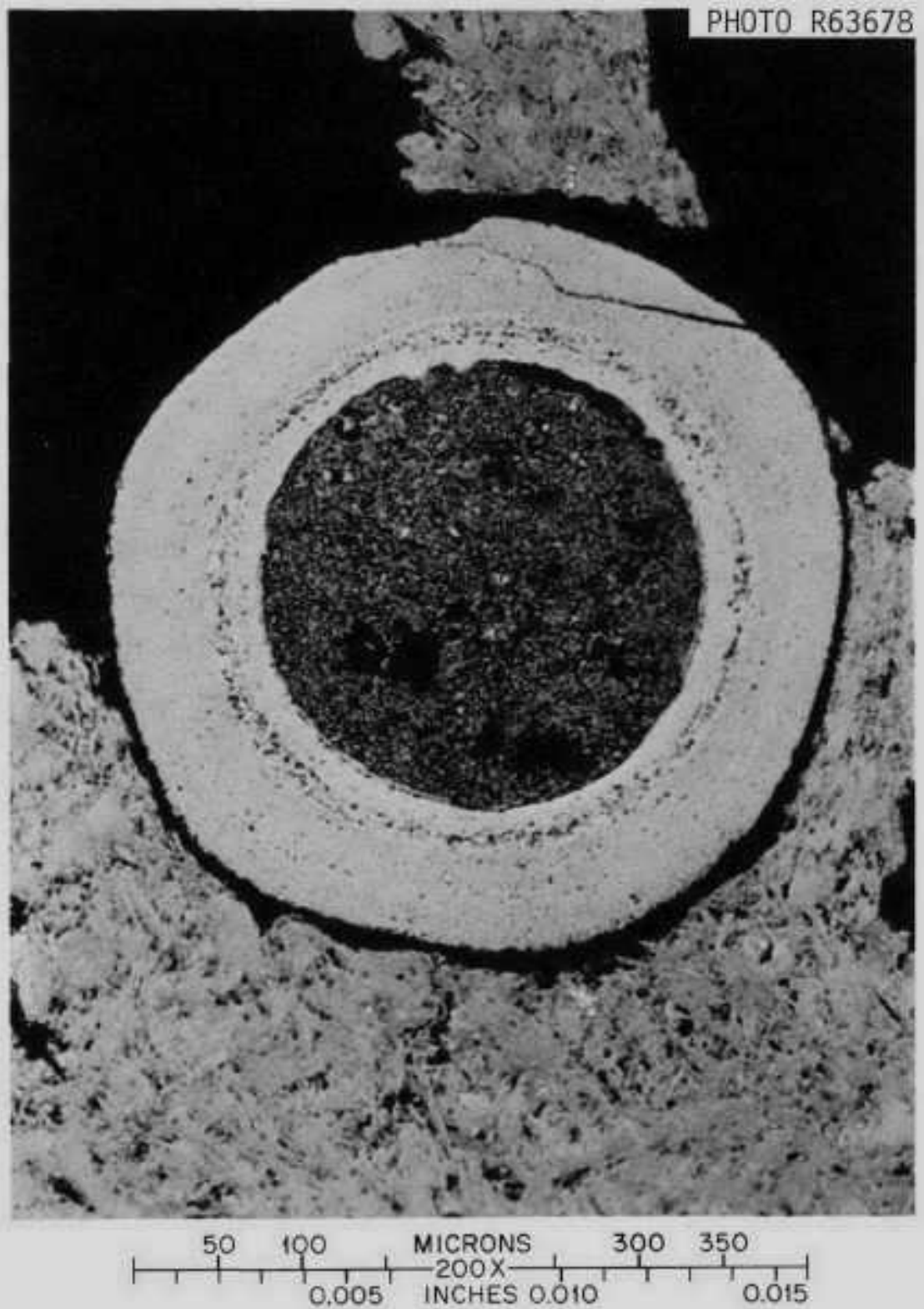

Fis. 4.21. Intact fuel particle at edge of matrix, showing damaged pyrocarbon coating. 

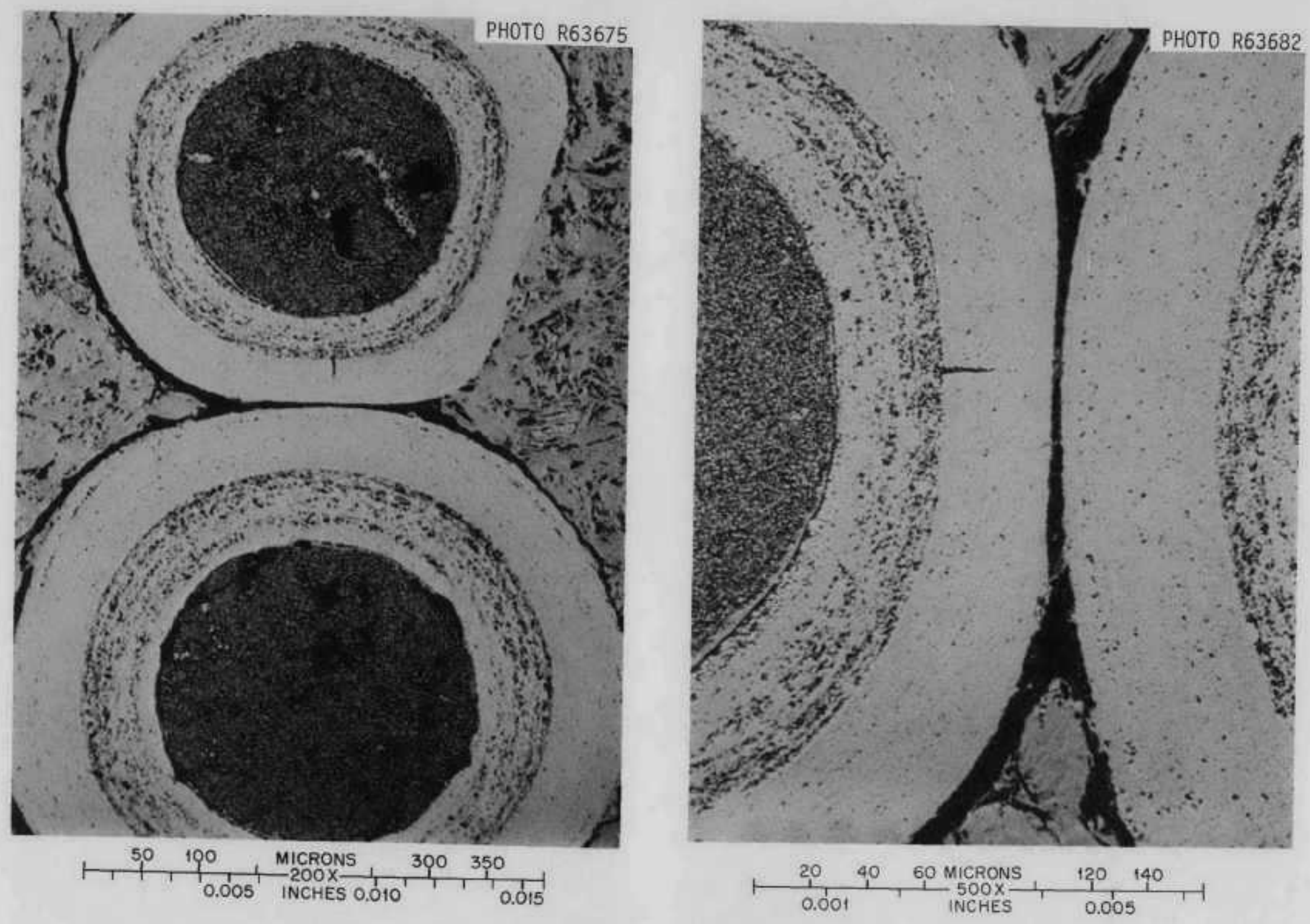

Fig. 4.22. Tuel particles with radiation-induced crack in outer pyrocarbon costing. 

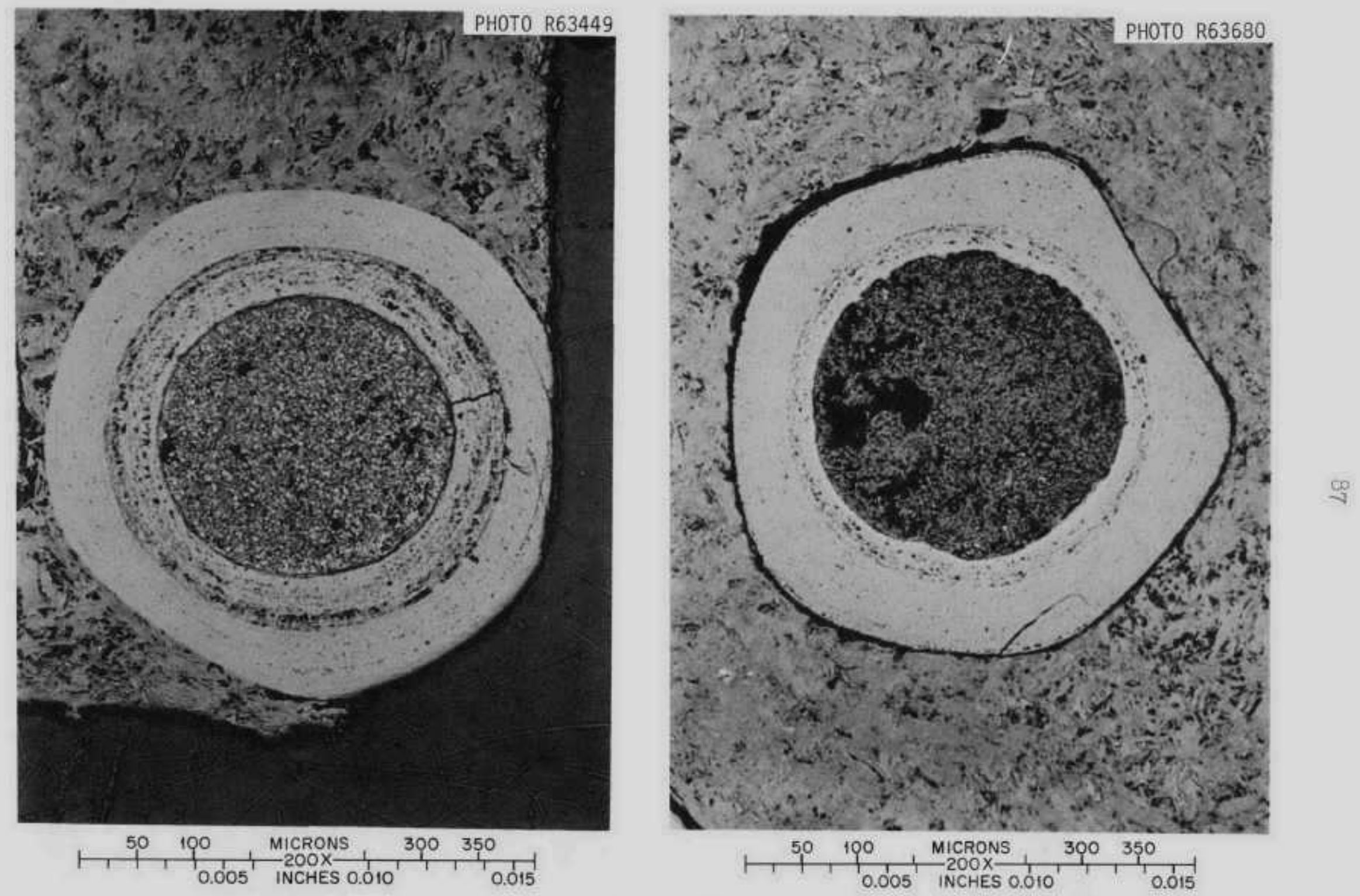

Fig. 4.23. Fuel particles exhibiting cracked buffer coating (Ieft) and damaged outer pyrocarbon coating (right). 

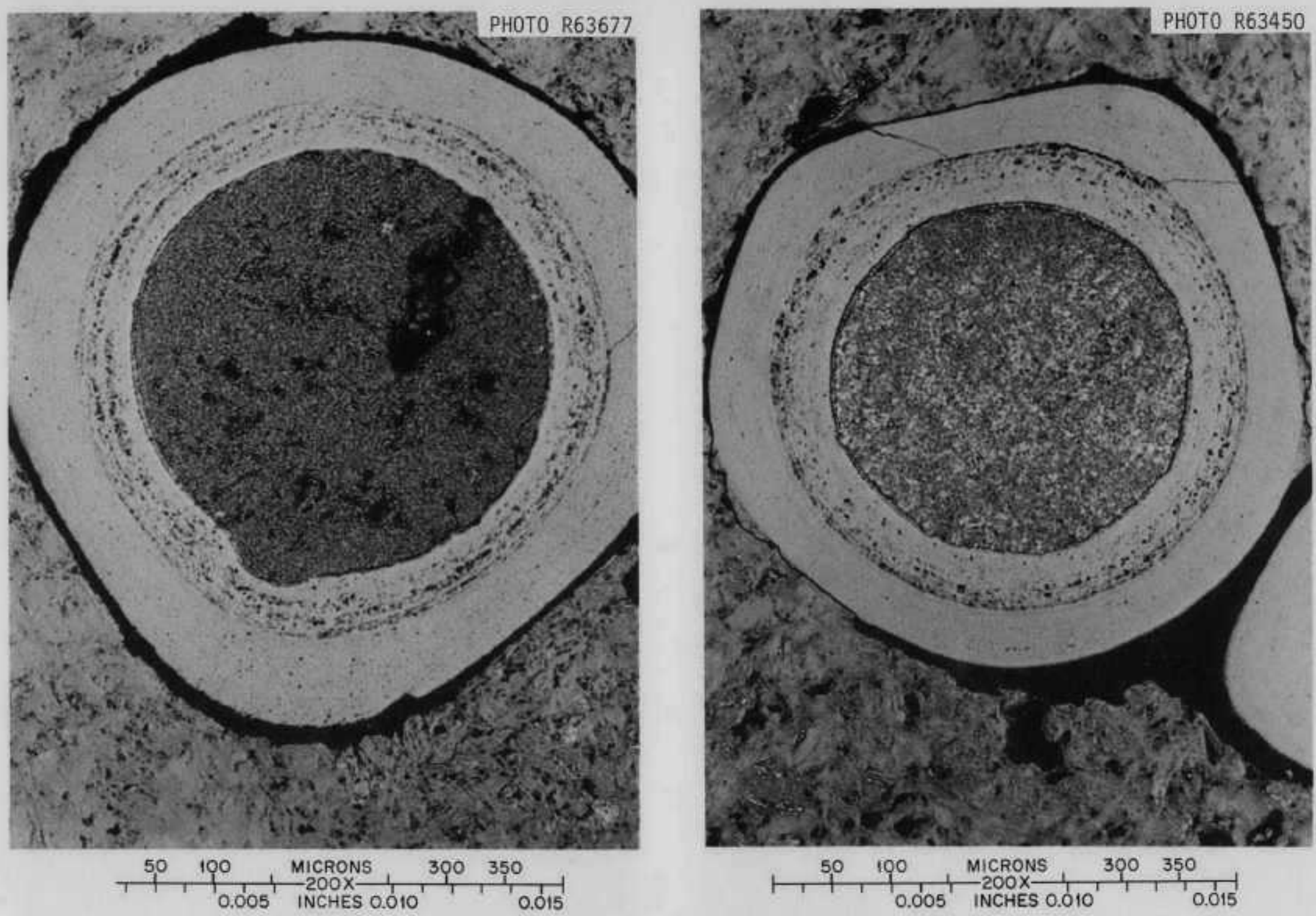

Fig. 4.24. Fuel particles exhibiting cracked outer pyrocarbon coeting. 


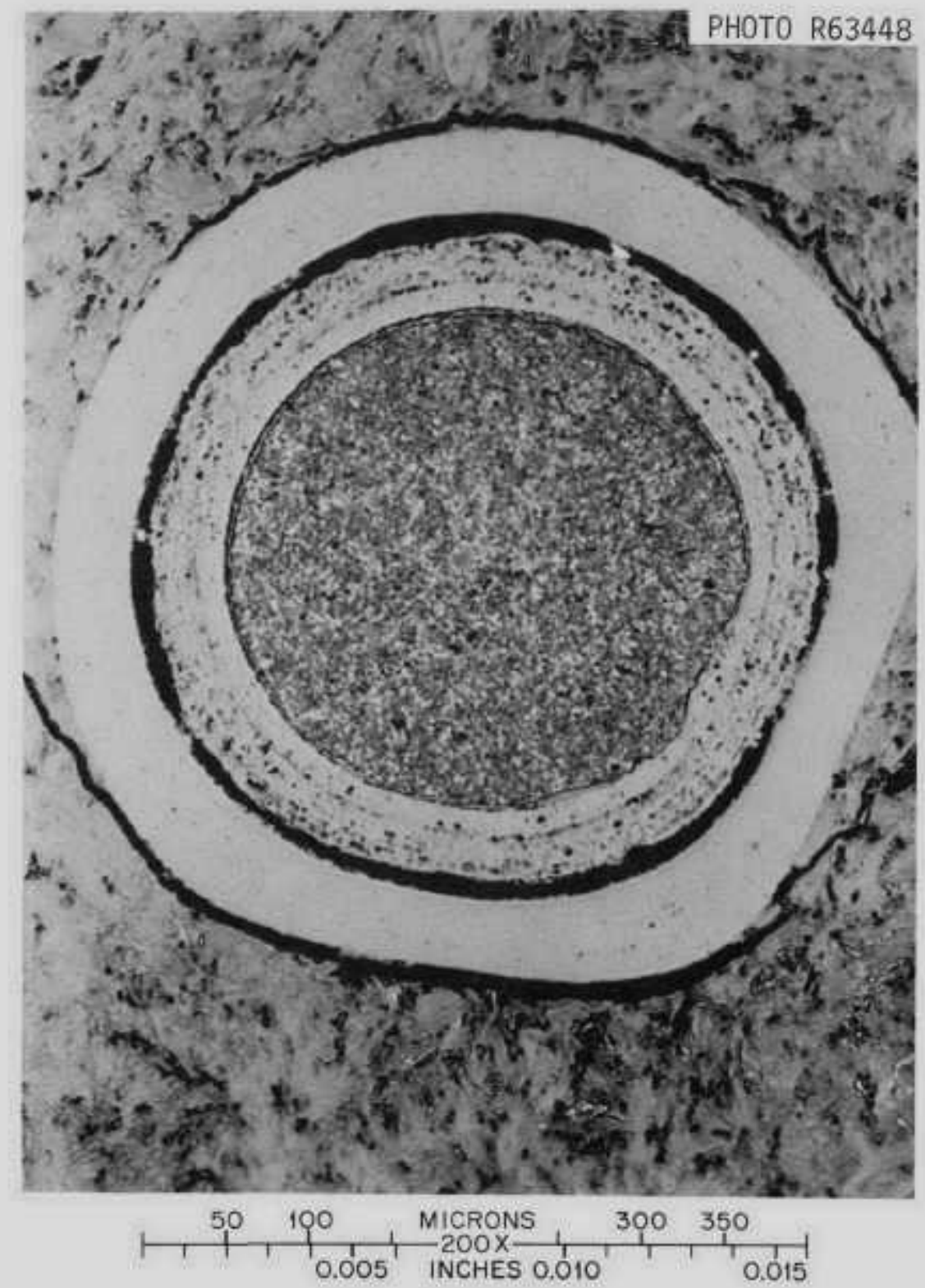

Fig. 4.25. Fuel particle exhibiting gap between buffer and outer pyrocarbon coating. 


\section{REFERENCES}

1. Peach Bottom Atomic Power Station, Final Hazards Summary Report, vol. II, Part C, NP-9115.

2. "Proposed Facility Change and Technical Specification Change No. 13," supplement to Final Hazards Summary Report, January 1970.

3. R. F. Thrner et a1., HTGR Fuel Performance in the Peach Bottom Reactor, GuIf-GA-A-12675 (JuIy 9, 1975).

4. Letter from David Hoppe (GAC) to M. L. Tobias (ORNL), dated Jan. 4, 1974 .

5. Letter from F. McCord (GAC) to C. F. Wallroth (GAC), dated June 27, 1975.

6. G. Buzzelli and R. H. Smith, Spectrophotometric Determination of Fission Zirconium in Irradiated Nuclear Fuels, GAMD-10072 (Feb. 12, 1973).

7. F. F. Dyer and E. McDaniel, Radionuclide Measurements with a Nuclear Data Model 4410 Computer-based Pulse Height Analyzer System (to be published).

8. F. F. Dyer and L. C. Bate, "Radionuclide Decay Data," ORNL Radiation Shielding Information Center Data Library Collection, DIC-I9 (1975).

9. M. Tobias, Estimates of Fission Product Inventories in Fuel Element E06-0I of the Peach Bottom Core 2: Results, Comparisons, and Sensitivity Study, ORNL-TM-4705 (October 1974).

10. Letter from R. S. Crouse (ORNL) to H. J. de Nordwall (ORNL), dated Jan. 25, 1974. 
ORNL-5126

UC-77 - Gas-Cooled Reactor Technology

\section{INTERINAL DTSTRIBUIION}

$\begin{aligned} \text { 1. } & \text { E. J. Allen } \\ \text { 2. } & \text { E. C. Beahm } \\ \text { 3. } & \text { R. I. Beatty } \\ \text { 4. } & \text { L. I. Bennett } \\ \text { 5. } & \text { E. S. Bomar } \\ \text { 6. } & \text { C. R. Brinkman } \\ \text { 7. } & \text { D. A. Canonico } \\ \text { 8. } & \text { A. J. Caputo } \\ \text { 9. } & \text { E. I. Compere } \\ \text { 10. } & \text { J.A. Conlin } \\ \text { 11. } & \text { J. H. Coobs } \\ \text { 12. } & \text { W. R. Corwin } \\ 13 . & \text { D. Costanzo } \\ 14 . & \text { J. A. Cox } \\ \text { 15-19. } & \text { F. F. Dyer } \\ 20 . & \text { W. P. Eatherly } \\ 21 . & \text { L. L. Fairchild } \\ 22 . & \text { J. I. Federer } \\ 23 . & \text { G. G. Fee } \\ 24 . & \text { D. E. Ferguson } \\ 25 . & \text { F. J. Homan } \\ 26 . & \text { O. J. Horne } \\ 27-64 . & \text { P. R. Kasten } \\ 65 . & \text { R. J. Kedl } \\ 66 . & \text { H. T. Kerr } \\ 67 . & \text { T. B. Lindemer } \\ 68 . & \text { E. L. Long, Jr. } \\ 69 . & \text { A. L. Lotts } \\ 70-74 . & \text { A. P. Malinauskas } \\ 75 . & \text { W. J. Martin } \\ 76 . & \text { W. R. Martin } \\ 77 . & \text { B. H. Montgomery }\end{aligned}$

78. M. T. Morgan

79. R. K. Nanstad

80. K. J. Notz

81. L. C. Oakes

82. A. R. Olsen

83. M. F. Osborne

84. G. W. Parker

85. R. L. Pearson

86. H. Postma

87. P. L. Rittenhouse

88. J. R. Robbins

89. G. C. Robinson

90. R. L. Shepard

91. Martha Stewart

92. V. J. Tennery

93. K. R. Thoms

94. D. B. Trauger

95. T. N. Washburn

96. J. R. Weir

97. J. C. White

98. G. D. Whitman

99-108. R. P. Wichner

109. R. G. Wymer

110-111. Central Research Library

112. Document Reference Section

113. Laboratory Records, ORNL-RC

114-123. Laboratory Records

124. Ken Davis (consultant)

125. J. C. Frye (consultant)

126. C. H. Ice (consultant)

127. J. J. Katz (consultant)

128. R. B. Richards (consultant)

\section{EXTERINAL DISTRIBUTION}

129. Research and Technical Support Division, ERDA-ORO, P. O. Box E, Oak Ridge, Tn. 37830

130. Director, Reactor Division, ERDA-ORO, P. O. BOX E, Oak Ridge, Tn. 37830

131-132. Director, Division of Nuclear Fuel Cycle and Production, ERDA, Washington, D.C. 20545

133-134. Director, Division of Reactor Research and Development, ERDA, Washington, D.C. 20545

135-301. Given distribution as shown in TID-4500 under category UC-77Gas-Cooled Reactor Technology 